\title{
LA CRÍTICA AL SUJETO DESPUES DE AUSCHWITZ EN LA FILOSOFIA DE THEODOR W. ADORNO
}

\author{
Gustavo Matías Robles
}

Tesis para optar por el grado de Magister en Historia y Memoria

Director Pedro Karczmarczyk, Universidad Nacional de La Plata Co-director: Alberto Pérez, Universidad Nacional de La Plata

La Plata, 6 de diciembre de 2012 


\section{RESUMEN}

El eje del presente trabajo será mostrar que en la obra de Theodor W. Adorno existe una relación entre la crítica al concepto de sujeto y el imperativo categórico qué el formula como petición de que Auschwitz no se repita. Nuestro objetivo será analizar tal relación, para mostrar de qué modo este imperativo categórico implica una autocrítica de la tradición filosófica, a los fines de sacar a luz aquellos elementos de la cultura que fueron cómplices de la ocurrencia de los campos de concentración. La idea que guía nuestro trabajo entonces es que el imperativo pos-Auschwitz que Adorno formula exige ser materializado mediante una crítica al concepto filosófico de sujeto de la modernidad. Esta hipótesis nos permitirá discutir dos puntos vinculados a esto: por un lado, nos permitirá indagar en la particularidad dialéctica y normativa del concepto de sujeto que Adorno formula y que lo distingue de otras críticas contemporáneas, y por otro lado, nos permitirá apreciar la relación entre reflexión filosófica y exigencia histórica a partir de la obra adorniana. 


\section{AGRADECIMIENTOS}

Agradezco en primer lugar a la Comisión Provincial de la Memoria de la Provincia de Buenos Aires, a la Universidad Nacional de la Plata, y al Consejo Nacional de Investigaciones Científicas y Tecnológicas por el apoyo financiero e institucional brindado.

A todos mis compañeros del grupo "Subjetividad y Lazo Social" dirigido por Pedro Karczmarczyk, y especialmente a él por su responsabilidad en la guía de mi trabajo y por su compromiso con la filosofía.

A los directores y a mis compañeros del Centro Interdisciplinario de Metodología en Ciencias Sociales (CIMeCS-UNLP).

A mis amigos y amigas de Tucumán, La Plata y Buenos Aires.

Y fundamentalmente a mi familia: a mi mamá, a mis hermanas Andrea, Cynthia y Melina, a mi abuela, a mi papá y al flamante nuevo integrante, Bautista. Y también a la madrina y al abuelo que siguen presentes. 


\section{SOBRE EL MODO DE CITACION}

Las citas de las obras de Adorno se indica siempre en primer lugar, entre corchetes, su procedencia según la edición alemana de las obras completas, y a continuación, entre paréntesis, la referencia de la traducción española. En caso de que de textos de los que no existe traducción sólo se referencia su edición en alemán. Las traducciones son en todos los casos propias. En los casos donde la traducción es problemática o se alude a términos que se reiteran en la obra Adorniana he optado por incluir fragmentos del original entre paréntesis y en cursiva.

Abreviaturas de las obras citadas:

[AP] Aktualität der Philosophie

[DA] Dialektik der Aufklärung

[MM] Minima Moralia

[DH] Drei Studien zu Hegel

[ND] Negative Dialektik

[ÄT] Äestetische Theorie

[PR] Prismen

[EN] Eingriffe

[SW] Stichworte

(MTK) Zur Metakritik der

Erkenntnistheorie

[NL] Noten zur Literatur

[PT I] Philosopie Terminologie I

[PT II] Philosphie Terminologie II

[SS I] Soziologische Schriften I

[SS II] Soziologische Schriften II

[PM] Probleme der Moralphilosphie
(AF) Actualidad de la Filosofía

(DI) Dialéctica de la Ilustración

(MM) Minima Moralia

(TH) Tres Estudios sobre Hegel

(DN) Dialéctica Negativa

(TE) Teoría Estética

(PR) Prisma

(IN) Intervenciones

(CN) Consignas

(MTC) Sobre la metacrítica de la teoría del conocimiento

(NL) Notas sobre Literatura

(TF I) Terminología Filosófica I

(TF I) Terminología Filosófica II

(ES I) Escritos Sociológicos I

(ES II) Escritos Sociológicos II 


\section{INTRODUCCION}

Una de las frases célebres por la que es conocido Theodor Adorno es aquella que enuncia, con el estatus de un nuevo imperativo categórico, "que Auschwitz no se repita". Sentencia breve pero cargada de una densidad semántica que muchas veces se diluye en el efecto de su contundencia. Dar cuenta de aquello a lo que esa frase alude exige ciertas precisiones y cierto recorrido por la obra adorniana; exige considerar esa sentencia como un momento en el transcurso de un pensamiento y, a la vez, como una respuesta filosófica ante los avatares de la historia. Es justamente esto lo que motiva nuestro trabajo. Será así que intentaremos poner en relación aquella célebre exigencia adorniana con el modo preciso en el que se somete a crítica el concepto filosófico y moderno de sujeto; es decir, intentaremos pensar el imperativo categórico en el marco de una discusión sobre el concepto filosófico de una subjetividad racional. Tenemos la confianza que, de este modo, tal imperativo categórico nos exhibirá todo su potencial crítico y su alcance filosófico. En resumen: intentaremos mostrar que, en el marco de la filosofía adorniana, dicho imperativo le plantea a la filosofía la necesidad de proceder con una crítica radical al concepto de subjetividad racional, en la medida en que, entre la constitución de la subjetividad moderna y el extermino masivo con métodos administrados de los campos de concentración, existiría cierta reciprocidad, cierta relación conceptual que será necesario llevar a auto-reflexión.

Este ejercicio nos exigirá particularizar la crítica adorniana en el contexto de otras críticas contemporáneas al concepto de sujeto, y resaltar la particularidad dialéctica y normativa que ese concepto presenta en la obra de Adorno. Según nuestro autor, los conceptos modernos de subjetividad y de racionalidad se refieren genealógicamente a una lucha por la supervivencia de la especie como herramienta de autoconservación. Como veremos en este trabajo, cuando la tradición filosófica, desde Descartes hasta entrado el siglo XX, conciba una idea de racionalidad en una relación entre un sujeto y un objeto no podrá apartarse de este origen; será así que dicha tradición se verá imposibilitada de pensar una experiencia que vaya más allá de una relación de manipulación e identificación cognitiva de su entorno; esta se encontrará detrás de la ciencia moderna como arquetipo de toda racionalidad. A lo largo del presente texto, intentaremos discutir de qué modo Adorno pensará este concepto de subjetividad y de racionalidad como ethos sobre el cual se hizo 
posible la ocurrencia de los crímenes masivos cometidos durante el siglo XX. Será entonces esta relación, no siempre clara ni exenta de problemas, la que será objeto de análisis en la presente tesis.

Entonces, confiamos que a partir de plantear como hipótesis que, en la obra filosófica de Adorno, existe un vínculo entre el imperativo categórico -que enuncia un problema histórico- y el concepto moderno de subjetividad racional -que exige una crítica filosófica- podremos aportar algo a la conflictiva relación entre historia y filosofía, no a partir de una contextualización externa al pensamiento, o del análisis de la influencia de las ideas en la historia cultural; sino mostrando que, ciertas preguntas filosóficas y la configuración de determinados conceptos, están atravesados por las necesidades que la historia plantea y sedimentados por relaciones sociales "pre-filosóficas" por decirlo de alguna manera. Para mostrar esto intentaremos leer la filosofía adorniana y ver cómo al interior de esta obra la preocupación por hacerse cargo del pasado reciente actúa como suelo vital del pensamiento. Es decir, intentaremos vincular sus análisis filosóficos y su crítica del concepto de sujeto y racionalidad con un intento por dar cuenta del pasado reciente, y al mismo tiempo, ver que los acontecimientos históricos también, y no solamente, pueden ser aclarados mediante la reflexión filosófica. Debido a esta doble relación confiamos en poder leer la frase "que Auschwitz no se repita" como una exigencia histórica a la filosofía de pensar sus propias categorías.

Entonces los objetivos principales de nuestra tesis serán:

Leer la crítica al concepto filosófico de subjetividad como una respuesta al pedido adorniano de que Auschwitz no se repita.

Estudiar la particularidad dialéctica y normativa del concepto de sujeto que Adorno formula y que lo distingue de otras críticas contemporáneas.

Estudiar la relación entre filosofía e historia a partir de la obra adorniana.

Dejemos un poco más en claro en esta Introducción los objetivos presentados hasta aquí.

“...que Auschwitz no se repita" 
Theodor Adorno nació en 1903 en Frankfurt, hijo de un rico comerciante de vinos judío y de una cantante italiana católica, y falleció en 1969 durante unas vacaciones de verano en Suiza. Su vida transcurrida durante la primera década del siglo XX le permitió contemplar, ya maduro intelectualmente, las transformaciones y las convulsiones históricas de esa primera mitad de centuria, que padeció estos sucesos de forma personal cuando se tuvo que ir al exilio debido a la persecución nacionalsocialista. Su reflexión tiene como punto de partida la experiencia histórica que le tocó vivir a su generación, más precisamente, la del intelectual judío de izquierdas de la Europa central. Los años en los que Adorno se formó intelectualmente estuvieron cargados de tensiones y acontecimientos que decretaron una transformación radical en el rumbo de la humanidad y que conmocionaron la vida de las personas sobre las que se desencadenaron: la dos guerras mundiales, la Revolución Rusa, el nazismo, la revolución cultural durante la República de Weimar, los campos de concentración, la bomba atómica, y luego la reacomodación europea, la desnazificación, la consolidación del estado de bienestar y hasta las revueltas estudiantiles a fines de los sesenta. Estos acontecimientos y transformaciones estarán en el centro de su obra.

Como dijimos, su obra puede ser leída como un intento persistente por retraducir los acontecimientos históricos a su medida filosófica, esfuerzo que no tenía como objetivo desarrollar una filosofía de la historia o algún tipo de cosmología donde esos sucesos empíricos quedaran acomodados en una secuencia previamente dispuesta, sino que más bien intentaba dar cuenta de esa experiencia histórica en la estructura y en el juego de los conceptos filosóficos, indagar en la singularidad de la historia a partir de su sedimentación filosófica. Esta exigencia de mediar la historia con la filosofía, y de pensar filosóficamente a la luz de las experiencias históricas tenía tanto que ver con una vocación intelectual como con una obligación moral. Puede decirse incluso que todo su pensamiento se articuló como un intento de dar respuesta a los interrogantes que tales acontecimientos presentaron, y que es, en esa medida, que la máxima que exige "que Auschwitz no se repita" [SW: 674] (CN: 80) puede ser considerada como el eje que recorrerá todo su trabajo intelectual.

Esta sentencia alude indudablemente al imperativo categórico kantiano, de modo que será en contraposición con éste que podrá hacerse más claro a qué está aludiendo Adorno. En 1785 Immanuel Kant publica su Fundamentación de la Metafísica de las Costumbres, obra en la que pretendía discernir la esencia de la moral y proponer un criterio 
para el obrar del individuo libre y autónomo, comprendiendo a todo sujeto racional en el seno de una comunidad moral regida bajo leyes universales y constituida sobre la incondicionalidad del imperativo, que debía guiar a priori todas las acciones consideradas morales. Su obligatoriedad sólo podía descubrirse de manera apriorística mediante el correcto uso de la razón y no mediante la experiencia, el aprendizaje o la condición humana. Esta ley moral podía ser expresada en tres imperativos categóricos que aclaraban sucesivamente su significado. El primero de ellos decía: “obra según la máxima que pueda hacerse a sí misma al propio tiempo ley universal" (Kant, 1983: 96), afirmación que nada nos dice de su contenido, sino que sólo nos indicaba la condición formal de la ley moral en tanto debía valer para todos los hombres siempre. Serán la segunda y tercera formulación del imperativo las que nos darán su contenido: 1) "obra según máximas que puedan al mismo tiempo tenerse por objeto a sí mismas, como leyes naturales universales" (Ibídem.: 97) y, 2) “obra con respecto a todo ser racional - a ti mismo y a los demás- de tal modo que en tu máxima valga al mismo tiempo como fin en sí” (Ibídem.). Según estas máximas, cada ser humano es autónomo porque puede generar por sí mismo la ley moral, en la medida en que es capaz, en virtud del factum de su razón, de legislar por sí mismo sin necesidad de someterse a una ley ajena. Es así que en la ética kantiana las ideas de racionalidad, humanidad, autonomía y universalidad se sostienen mutuamente y expresan el optimismo ilustrado en el que fueron pensadas.

Por supuesto que este optimismo se tornó problemático luego de la ocurrencia de Auschwitz, y tal estado es lo que intentará expresar Adorno con su reformulación del imperativo categórico. Luego de lo ocurrido en los campos, donde millones de vidas fueron exterminadas de la forma más fría y mecánica posible, no era sencillo guardar la misma confianza en una racionalidad que dictara normas universales a sujetos autónomos. Esta ética era para Adorno parte de una época irrecuperable, asentada en una confianza ilustrada que se volvió ingenua, cuando no sospechosa. La filosofía necesitaba pensar un nuevo imperativo a la luz de las masacres y los sufrimientos padecidos, un imperativo que no sólo tuviera otro contenido, sino también otra forma. La simple sentencia "que Auschwitz no se repita" da de lleno con esta necesidad. Este imperativo categórico no surge del principio de la razón pura, sino de la experiencia histórica, no expresa un ideal de humanidad, sino la 
existencia acusadora de un genocidio, no se trata de una aseveración afirmativa, sino de una negación que pide evitar la repetición de aquella experiencia histórica.

El contenido de este imperativo puede ser traducido en la solidaridad con las víctimas, actitud que no se basa en un razonamiento ni es susceptible de fundamentación normativa como se afirma en el siguiente párrafo:

Hitler impuso a los hombres en el estado de su no-libertad (Unfreiheit) un nuevo imperativo categórico: orientar su pensamiento y su acción (Denken und Handeln) de tal modo que Auschwitz no se repita, que no ocurra algo similar. Este imperativo es tan reacio a su fundamentación (Begründung) como en otro momento el hecho (Gegebenheit) del kantiano. Tratarlo discursivamente sería un crimen: en él se hace presente el momento del acercamiento corporal a lo ético (das Moment des Hinzutretenden am Sittlichen) [ND: 358] (DN: 365)

No fundamentar el imperativo no implica renunciar al pensamiento ante el espanto ya que no es el gesto del aterido el que Adorno reivindica. Este rechazo de fundamentación se debe a que el imperativo se asienta en la experiencia de una compasión, y no en una intelección o en alguna forma de deducción lógica. El imperativo se da de forma negativa como rechazo compasivo ante el dolor externo, no como afirmación racional de una tesis; constituye una exigencia de abrir la sensibilidad ante el dolor corporal del otro y no un razonamiento cuyas premisas nos coaccionan a acatarlas. Los imperativos morales se expresarían para Adorno en un "no harás esto", no torturarás, no harás sufrir, frases que "son verdaderas como impulso (Impuls) si se da cuenta de que en algún lugar se ha torturado" (ND: 281, DN: 282). Someter ese impulso moral al esquema de la consecuencia lógica es, como veremos, someterlo al principio de cosificación social al que ese impulso se opone:

El impulso, el desnudo miedo físico y el sentimiento de solidaridad con los cuerpos torturables (quälbaren Korpen) [...], que es inmanente a la conducta moral, sería negado por el afán de una racionalización despiadada; lo más urgente se convertiría de nuevo en contemplativo, una burla a su propia urgencia [ND: 281] (DN: 283).

Para Adorno explicar el impulso que motiva el imperativo sería insertarlo como un eslabón más en una cadena de consecuencias, neutralizar su potencia conmovedora en una secuencia de pasos deductivos; es decir, sería colocarlo bajo la misma lógica de igualación que constituye el ethos sobre el que se hizo posible Auschwitz. El nuevo imperativo no debe basarse en la razón, sino en la evidencia corporal del sufrimiento, “en la repugnancia 
convertida en práctica al inaguantable dolor físico al que están abandonados los individuos...” [ND: 358] (DN: 365). Es en ese materialismo en el que se asienta su carácter normativo, por lo que comprenderlo no implica abandonar toda racionalidad para asumir algún tipo de empatía no mediada conceptualmente, sino ampliar la racionalidad mediante aquellos elementos afectivos y compasivos que fueron civilizatoriamente reprimidos.

Adorno sabe que suspender la conciencia ante el horror será un signo del triunfo del horror, por el contrario la filosofía debe buscar comprenderlo, darle una explicación para que no prosiga en su carácter paralizador. Sólo en esa paradoja sería pensable la filosofía y la cultura: "sólo esta contradicción es hoy, a la vista de la impotencia real de cada uno, el escenario de la moral" [ND: 282] (DN: 283). Esta situación aporética de la moral sería la situación en la que se encuentra toda la cultura luego de Auschwitz, y es justamente en esa aporía en la que hay que pensar. Esa aporía marca las condiciones objetivas de todo pensamiento, la situación de la que debe partir y que no puede resolverse sólo en el plano de las categorías.

En un sentido similar, Adorno había formulado en 1949 una célebre sentencia en la que decretaba como acto de barbarismo escribir poesía después de Auschwitz [PR: 30] (PR: 42). Sentencia un tanto abrupta y paralizante escrita apenas cuatro años después de terminada la Segunda Guerra Mundial, sorprende lo precoz de este llamado en un momento en el que no abundaban las voces intelectuales que denunciaran lo que había ocurrido en los campos ${ }^{1}$. Esa sentencia daba lugar ciertamente a una mala interpretación ya que parecía condenar a la suspensión de toda praxis cultural y al simple abandono de la reflexión. Es por esto que en 1969 en su Dialéctica Negativa retoma, de forma más matizada, aquella afirmación:

El sufrimiento perene tiene tanto derecho a la expresión como el martirizado a gritar; por eso puede haber sido falso que después de Auschwitz ya no se pueda escribir poesía. Pero

1 Enzo Traverso en un estudio sobre la relación de algunos intelectuales con Auschwitz como problema describe diferentes posiciones mantenidas en los primeros años luego de terminada la guerra, posiciones que van desde la simple minimización hasta la franca ignorancia, pero que también cuenta con particulares excepciones en pensadores para quienes Auschwitz fue tempranamente tema central de sus preocupaciones, tales como Hanna Arendt, Siegfried Krakauer, Max Horkheimer o Theodor Adorno. Todos ellos intelectuales alemanes de origen judío que escribieron desde el exilio; justamente esa condición de exilio y marginalidad será lo que según Traverso les proporcionará cierta "superioridad epistemológica" ya que los situaría "por encima de los puntos de vista estrechos, las ideas preconcebidas y las mentalidades tradicionales de los diferentes grupos nacionales o políticos". Debido a esto "los exiliados son los únicos que pueden pensar Auschwitz porque son los únicos que pueden identificarse con las víctimas del genocidio y estar en condiciones de pensar ese desgarro de la historia" (Traverso, 1997: 48-49) 
no es falsa la cuestión menos cultural de si después de Auschwitz se puede seguir viviendo, sobre todo si puede hacerlo quien casualmente escapó y a quien legítimamente (rechtens) tendrían que haber sido asesinado [ND: 355] (DN: 363).

El sufrimiento tiene derecho a ser expresado y esta es la exigencia que la historia le impone a la filosofía: la obligación de dar expresión a lo que sucedió en Auschwitz con sus propios medios. Pero en esta cita Adorno dice algo más: esa obligación le viene no porque se encuentre en una posición institucionalmente privilegiada o porque guarde cierta dignidad epistemológica. Todo lo contrario. La obligación de la filosofía se fundamenta en que ésta comparte la "culpa" del superviviente: la cultura se encuentra en la situación del que logró no perecer en los campos sólo debido al azar, azar que no persigue ningún ideal de justicia ni construye ningún sentido. En la medida en que el filósofo podría haber fenecido y, sin embargo, no lo hizo es que se ve comprometido a expresar la voz de las víctimas que ocuparon su lugar. El privilegio -inmerecido- del que logró sobrevivir es lo que le otorga a la cultura, y con ella a la filosofía, la responsabilidad de expresar el sufrimiento de las víctimas.

La experiencia filosófica fundamental para Adorno ya no es el abstracto "¿por qué el ser y no más bien la nada?” heideggereano, sino el tremendamente concreto "¿por qué aún estoy vivo y otros perecieron en mi lugar?", pregunta que da cuenta de ese privilegio inmerecido y casual que hace que no se pueda hablar de una "vida justa", sino más bien de una supervivencia en medio de una "vida dañada". En ese momento es absurdo afirmar que la vida tenga un sentido o postular cualquier cosmología tras acontecimientos "que llevan a burla la construcción de un sentido de inmanencia" [ND: 354] (DN; 361). La filosofía es necesaria sin embargo porque debe dar cuenta de la destrucción del sentido, sin arrogarse el derecho de decretar otros y, también, debe mostrar en qué medida el sentido que se ha destruido fue cómplice de su misma destrucción. Es por esto que el imperativo exige una filosofía crítica que denuncie toda reconstrucción racional de una historia cargada de significado teleológico, en el que los sufrimientos padecidos encontrarían su justificación en un suerte de plan providencial.

Entonces, la filosofía acorde a tal estado de la cultura debe ser crítica de su propia complicidad con la ocurrencia de la barbarie. Adorno se hace eco del díctum benjaminiano que afirmaba que no hay documento de cultura que no sea a la vez documento de barbarie (Benjamin, 1989: 186), ya que esa misma cultura forma parte sustantiva del suelo desde el 
cual surgió la destrucción: "toda la cultura después de Auschwitz, junto con la urgente crítica contra ella, es basura" [ND: 359] (DN: 367), completaba Adorno la afirmación benjaminiana. Si bien la filosofía no fue un verdugo directo, sí contribuyó a legitimar y expandir las condiciones sobre las cuales se forjaron los caracteres que luego hicieron posible el accionar de esos verdugos. La filosofía fue responsable en tanto expresión y delimitación de los conceptos con los que la cultura, que hizo posible Auschwitz, pensó su posición en el mundo; fue responsable en tanto ayudó a crear las condiciones conceptuales sobre las cuales se naturalizó la manipulación de los seres vivos como si fueran cosas. Condiciones que se expresaron en un determinado "contexto de frialdad" mediante el cual fue posible asesinar sin sentir odio y por lo que millares de vidas fueron exterminados sin consideración moral alguna. Para Adorno esta "frialdad" constituye el "principio fundamental de la subjetividad burguesa sin el que Auschwitz no habría sido posible" [ND: 356] (DN: 363). Es precisamente en la complicidad con ese principio de frialdad, como estructura de toda subjetividad, lo que hace responsable a la filosofía y a lo que alude el nuevo imperativo categórico adorniano.

En este contexto, "que Auschwitz no se repita" alude a una exigencia de desactivar esa frialdad que, como fisonomía de toda subjetividad, es también la condición civilizatoria para que los verdugos pudieran llegar hasta donde llegaron. En última instancia, el nuevo imperativo categórico implica someter a una crítica el modelo de subjetividad que hizo posible tal situación. La tarea de la cultura "pos-Auschwitz" entonces consistiría en tratar de dar cuenta del concepto reificado de sujeto que esa cultura ha enarbolado y que se encuentra como condición de la barbarie. Así lo dice claramente Adorno en una conferencia de 1966 llamada "La educación después de Auschwitz": "es necesario lo que en este sentido llamé el giro hacia el sujeto (die Wendung auf Subjekt)", con el fin de "reconocer los mecanismos que hacen a los hombres capaces de tales atrocidades..." [SW: 675] (CN: 82). El trabajo de descubrir tales mecanismos implica llevar a cabo una crítica al modelo de subjetividad presente en la cultura a lo largo de la modernidad.

Pensar después de Auschwitz implicará entonces iniciar una crítica al concepto de sujeto tal y como hasta entonces había sido concebido, para descubrir en él los mecanismos que expliquen por qué los hombres han sido capaces de tales atrocidades, pero también para descubrir aquello que contribuiría a que eso no vuelva a tener lugar. Indagar en la forma de 
construcción de la subjetividad durante la modernidad tendrá para Adorno entonces el carácter no sólo de una necesidad filosófica, sino también de un imperativo moral y político. El pedido "que Auschwitz no se repita" será entendido como una crítica a la "conciencia cosificada" que inmunizó a los hombres ante el dolor ajeno y que hizo posible el asesinato burocratizado y técnicamente administrado.

De ese modo, pensar una filosofía después de Auschwitz es fundamentalmente pensar en términos filosóficos una crítica al sujeto en tanto elemento central de la cultura en la que tuvieron lugar las masacres. Esa incapacidad de identificarse con el dolor ajeno fue a los ojos de Adorno "la condición psicológica más importante para que pudiese tener lugar algo como Auschwitz entre hombres bastante educados y mansos" [SW: 687] (CON: 92). Esa situación aporética que describimos antes y que es el universo en el que debe desarrollarse la filosofía exige encauzar una crítica al concepto de sujeto, sin renegar de la racionalidad pero haciéndose cargo de ese momento de compasión y consideración con las víctimas que la racionalidad debe abrigar.

Como dijimos, nuestra hipótesis de lectura será que en la filosofía Adorniana habría una estrecha vinculación entre el imperativo categórico que él formula y una crítica filosófica al sujeto racional de la modernidad. Es por eso que ahora será conveniente ofrecer algunas precisiones sobre los términos de dicha crítica.

Sobre la crítica al sujeto

El ejercicio de crítica del sujeto y del concepto de racionalidad moderna que nosotros pretendemos entender como exigencia histórica, se presenta también como un giro realizado por cuestiones internas al campo filosófico. Es así, que la filosofía contemporánea puede ser interpretada como el intento de descentramiento del sujeto sobre el cual se fundó todo el pensamiento moderno desde Descartes hasta entrado el siglo XX. En esas filosofías el sujeto se ofrecía como garantía, causa y origen del significado, del mundo, de la historia, de la acción, de los intentos de emancipación, del saber... Pero fundamentalmente este modo de pensar el sujeto estuvo signado por la obsesión en la búsqueda de criterios fiables para todo acto de conocimiento y para toda acción, criterios que debían estar radicados en un sujeto autónomo. Esta búsqueda de garantías subjetivas se aferraba a instancias como la conciencia, el sujeto trascendental, la experiencia subjetiva, la certeza sensible, etc., de 
modo tal de construir una praxis efectiva y un conocimiento correcto. Toda filosofía del sujeto contenía ciertas premisas que se iban a repetir en los diferentes sistemas. Entre estas alguna de estas premisas se encuentran las idea de que: -el sujeto debía ser el fundamento del conocimiento verdadero y la acción eficaz; -los significados y sentidos mentados eran productos de actos mentales o representaciones, -la relación fundamental que ese sujeto establecía con el mundo era la relación de objetivación cognitiva o de dominación material.

La multiplicidad de narrativas que encarnaron este giro contra las filosofías de la conciencia fue bastante variada y estuvo asentada en diferentes problemáticas ${ }^{2}$; si bien es innegable que ya estaban presentes en Kant y en Hegel, sólo podemos decir que irrumpen con toda su fuerza y de modo explícito con Nietzsche y su crítica a la verdad y la moral como evidencias de nuestra cultura, con Marx y su relevamiento de las relaciones sociales y los procesos históricos en los que el hombre se inserta, y con Freud y su crítica a la identificación entre actividad consciente y actividad psicológica (Foucault; 1984). Lo que estas filosofías anti-representacionalistas hicieron fue socavar las pretensiones de autonomía de esa subjetividad, por lo que el sujeto dejaba de estar planteado como algo dado y comenzaba a ser pensado como consecuencia, no como causa sino como efecto, no como garantía sino como certeza construida y frágil, más como el resultado de un proceso previo, un estadio devenido en el que diversos condicionamientos tenían lugar. Este entrecruzamiento de condicionantes es lo que podemos denominar "procesos de

2 Es provecho considerar el mapa que Albrecht Wellmer ofrece de tres modos distintos de llevar a cabo la crítica del sujeto y de la razón en la filosofía contemporánea, que están de algún modo vinculadas con las críticas del posmodernismo al racionalismo, estos tres modos de crítica serían: 1) la crítica psicológica del sujeto y su razón, 2) la crítica de la razón instrumental y su lógica de la identidad y 3) la crítica al sujeto constituyente de sentido en la filosofía del lenguaje wittgenstenianna. La primera crítica consiste en la constatación de la impotencia fáctica de la racionalidad del sujeto pretendidamente autónomo, para Wellmer se trata del "descubrimiento de lo 'Otro' de la razón en el interior del sujeto y su razón”; el yo es entendido como un simple mediador entre fuerzas que lo rebasan (pasiones, libido, fuerzas sociales que se impregnan en su carácter). La segunda crítica aparece con Nietzsche y se desarrolla con Adorno y el pos-estructuralismo francés; esta crítica pone la relación entre sujeto, objeto y concepto sobre la base de relaciones de sometimiento y poder que las determinan, y ante la cual el sujeto termina volviéndose una instancia impotente producto de un acto de violencia que los precede. La tercera crítica alude al sujeto como fuente de las significaciones lingüística, es decir critica la tesis de que el sujeto sería el responsable de establecer las coordinaciones entre signos y cosas mediante actos volitivos autónomos. Esta crítica intenta mostrar esa instancia previa a toda intencionalidad que son los sistemas lingüísticos de significaciones, las formas de vida abiertas lingüísticamente; en ese sentido la significación no remite su criterio a ninguna intencionalidad sino a la práctica de un uso lingüístico compartido. (Wellmer, 1993: 74-88). 
subjetivación", y es justamente el develamiento de estos procesos lo que va a interesar a la crítica contemporánea.

La filosofía de Adorno también puede ser insertada en esta tradición crítica, y será allí donde buscaremos su singularidad. La crítica al sujeto ofrecida por Adorno nos llevará a indagar en una lectura del imperativo categórico pos- Auschwitz, así como nos dará herramientas para sacar ciertas consecuencias novedosas de su filosofía. Para precisar los contornos de la crítica adorniana al concepto de sujeto, nos valdremos de una cita en la que consideramos se encuentran expuestas sus principales líneas. Para Adorno el problema está en tanto se conciba que:

[...] las intervenciones, las intelecciones, el conocimiento, son solamente subjetivos [...]. Ilusión es el encantamiento (Verzauberung) del sujeto en su propio fundamento de determinación(eigenen Bestimmunsgrund); en su posición como ser verdadero. Es preciso retrotraer al sujeto mismo a su objetividad; no se trata de proscribir sus impulsos al conocimiento. [SW: 749] (CN: 150).

Pero esta "ideología del sujeto" "ya no surte efecto tan pronto la subjetividad es comprendida como figura de objeto" (Op. Cit). El problema estaría cuando concebimos al sujeto como autónomo en su propia esfera y como origen y causa de las representaciones, en ese caso seríamos víctimas de una ilusión que no nos permitiría ver ninguna exterioridad no subjetiva, que encerraría al espíritu en sí mismo y anularía todo aquello que pudiera desmentirlo. En este marco, el sujeto sería el resultado de un cierre que se efectúa mediante múltiples represiones y que provoca la ilusión de una instancia homogénea y autónoma, pero empobrecida en su comunicación con toda exterioridad.

Pero, ¿qué es lo que se reprime en la constitución de esta subjetividad?. Esto lo contesta Adorno cuando a reglón seguido pasa a indicar las tareas que le corresponden a la crítica ante este sujeto solidificado: "El sujeto mismo debe ser restituido a su objetividad, sin la intención de proscribir sus impulsos al conocimiento (nicht sind seine Regungen aus der Erkenntnis zu verbannen)" (Op. cit.), puesto que esta forma ideológica “deja de surtir efecto en el momento en que la subjetividad es descubierta como figura del objeto (Gestalt vom Objekt)" (Op. cit.). De modo que, para dar cuenta de la crítica adorniana a la subjetividad debemos mostrar que el descentramiento que Adorno produce del sujeto está realizado a partir de la búsqueda de cierta "figura del objeto" capaz de abrir ese "encantamiento" que lo encierra "en su propio fundamento" autónomo. Lo interesante del 
análisis de esta construcción ideológica es que aquello que ese sujeto reprime para constituirse es justamente aquello sin lo cual no podría existir; es decir, que el sujeto para ser autónomo debe ocultar y reprimir sus propias condiciones de posibilidad. Entonces, la tarea de la crítica será reponer esa instancia reprimida y destruir el encantamiento que aprisiona al sujeto, de modo tal que los "impulsos al conocimiento" no sean proscriptos sino potenciados. Debemos ver entonces a qué alude esa objetividad reprimida y cómo se da esa represión.

En este breve fragmento tenemos ya presente todos los principales lineamientos de la crítica al sujeto adorniana. El sujeto consistiría, según esta presentación, en una instancia paradójica que para poder funcionar como tal, es decir para poder constituirse como sujeto, debe reprimir aquello sin lo cual nada sería: una figura que oculta las huellas de su propia posibilidad. Entonces, podemos decir que el sujeto es una ideología ya que es el producto de un cierre que se efectúa por medio de ciertos mecanismos que analizaremos en este trabajo y mediante los cuales se reprime posteriormente aquella objetividad que es su condición de constitución. Este sujeto ideológicamente constituido pone en acto mecanismos de represión al interior de sí mismo que luego se reproducirán como relaciones y estructuras sociales cosificadas. La crítica de la "ideología del sujeto" se va a preocupar entonces en develar los mecanismos de articulación y constitución de la forma ideológica sujeto a partir de una reposición de esa objetividad que lo constituye.

El concepto moderno de sujeto fue pensado como portador de una racionalidad que era capaz de otorgar sentido a todos los ámbitos del mundo, que permitía tanto un conocimiento verdadero como un accionar eficaz. Racionalidad apta para definir completamente los fenómenos o para dar con las leyes que los gobernaban. Sujeto y racionalidad fueron términos que la tradición siempre consideró como equivalentes y como reducibles uno a otro. Lo que Adorno realizará con su crítica será escindir ambos términos mostrando que la racionalidad, tal y como fue concebida por la tradición, es en realidad sólo un aspecto en el encuentro entre el sujeto y su mundo, y que ese sujeto racional es en realidad el producto de una serie de instancias históricas no necesariamente racionales.

El sujeto se constituyó como instancia cerrada sobre sí misma que sólo podía entablar relaciones cosificadas con su entorno; de este modo las disposiciones de control técnico y de identificación cognitiva adquirieron primacía sobre las dimensiones miméticas 
y sensibles que hicieron mella en su capacidad experiencial. Esa "regresión" de la experiencia que determina "la incapacidad de poder oír con los propios oídos aquello que no ha sido escuchado, de tocar con las propias manos lo aún no experimentado (Unergriffenes)" [DA: 53-54] (DI: 89) es el problema central de esa subjetividad. Para este sujeto racional la experiencia sólo es concebida como relación de identificación y catalogación abstracta de las singularidades en el marco de sus categorías subjetivas; es decir, la experiencia sólo es confirmación de la subjetividad, no apertura ni encuentro con una realidad distinta y singular. Es este modelo de subjetividad el que posibilitó la emergencia de individuos dañados y cosificados en sus capacidades experienciales y morales, y lo que según Adorno creó el contexto de frialdad en el que fue posible la barbarie de Auschwitz.

Uno de los objetivos del trabajo será entonces especificar esta crítica filosófica al concepto de sujeto que expusimos muy someramente, y ver en qué medida dicha crítica está exigida por el imperativo categórico pos-Auschwitz. Intentaremos mostrar entonces cómo es que ese contexto de frialdad sobre el que se constituye el sujeto de la modernidad es el ethos cultural del terrible desenlace histórico.

Veremos también que la crítica adorniana no será una simple demolición del sujeto, sino un rescate de sus elementos críticos y una ampliación de su racionalidad. Todo nuestro trabajo tendrá como eje mostrar que la crítica adorniana al sujeto se encuentra en la paradójica posición de, por un lado, reconocer el papel ideológico que este sujeto autónomo representa - como garante y reproductor de relaciones de dominio y represión-; pero, por otro lado, mantener la conciencia de que la demolición de tal sujeto no es menos ideológica. Es decir, que en algún punto esa crítica al sujeto es funcional o puede estar interesada en la preservación del orden social vigente, en la medida en que con ella vaya incluido un abandono a los potenciales normativos e ilustrados que ese sujeto contiene. En la medida en que esa demolición del sujeto esté en contra de las posibilidad de un empoderamiento de los individuos sobre sus propias condiciones de existencia. La siguiente observación que realiza Frederick Jameson, defendiendo la crítica adorniana en el mismo sentido que queremos defenderla aquí, puede dejar un poco más en claro esta idea:

También se puede argumentar que esta tendencia contemporánea [la demolición crítica al sujeto] repite las tendencias y los intereses del Estado Moderno y del capitalismo monopólico: 
puede verse a estos últimos participar en la planificación de lo individual, la reducción de la elección individual y subjetiva en la era de la sociedad organizada, la penetración y la colonización por las fuerzas del mercado del anterior ego autónomo, y también del inconsciente y del deseo. (2010: 196).

Por lo tanto, tendremos que tener siempre presente el carácter dialéctico de esa crítica, en la medida en que la exigencia de que Auschwitz no se repita también implicaría la exigencia de fidelidad a los ideales que fueron ridiculizados con la existencia de los campos de exterminio. Uno de los objetivos del trabajo será entonces especificar esta crítica filosófica al concepto de sujeto que expusimos muy someramente, y ver en qué medida dicha crítica está exigida en el imperativo categórico adorniano y que constituye el suelo moral sobre el que la filosofía debe ejercerse.

Por lo tanto, si la tarea que le compete a la filosofía luego de Auschwitz consiste en indagar en las condiciones histórico-filosóficas que hicieron posible que hombres comunes y corrientes participaran en las masacres más terribles que la humanidad haya conocido, entonces, lo primero que hay que revisar es el marco en el cual fue forjado el carácter de los verdugos, así como el de todos aquellos que permanecieron impávidos ante el sufrimiento. Hay que indagar en ese contexto de frialdad que permitió que Auschwitz pudiera ser naturalizado e insertado en una continuidad como si fuese el cumplimiento de un designio o bien, un suceso lamentable pero explicable dentro del marco de una guerra. El interés por hacer visibles las condiciones de la barbarie llevará a Adorno a indagar en la figura del sujeto de la filosofía, parte de una cultura que demostró su fracaso.

Ahora bien, antes de describir el orden de exposición conviene realizar algunos comentarios sobre las dificultades que presenta la obra adorniana para el presente trabajo. En la confección de un texto académico existen ciertas estipulaciones en cuanto al estilo de escritura, requisitos que tienen que ver con la claridad expositiva y la correcta ordenación de los argumentos. Esto, que de alguna manera se encuentra naturalizado como un valor, se torna un problema a la hora de entablar un diálogo crítico con la obra de un autor que hace de la violencia de esos requisitos una parte sustantiva de su pensamiento. En Adorno subyace la idea de que los pensamientos tienen el mismo valor que la forma lingüística en la que son plasmados, por lo que el modo de exposición adquiere un rango que roza la experimentación. Esto no responde a una deriva literaria, sino a un interés teórico por sacar 
a luz los aspectos de la comunicación y del lenguaje que él considera "reificados", es decir responde a un interés "crítico". Por esto, creo la observación sobre las dificultades para exponer y estudiar el pensamiento adorniano no indica una simple coquetería académica, sino que conduce directamente al corazón de lo que estamos estudiando.

En la medida en que la filosofía de Adorno encuentra su interés en la crítica al pensamiento conceptual, pero sin abandonar una idea enfática de racionalidad, a todo trabajo académico sobre su obra siempre se le presentará la pregunta de cómo hacer justicia a un pensamiento que intenta sustraerse de toda presentación lineal o estandarizada. Esto obliga a negociar constantemente la forma expositiva y nos plantea una paradoja ya que por un lado no podemos sin más emular la exposición adorniana -no sólo por los requisitos institucionales, sino porque esa forma está delimitada a un modo particular de pensar que no es exactamente el nuestro-; pero, por otro lado y al mismo tiempo, amoldar su pensamiento a una ordenación a la cual rehúsa intencionalmente es de algún modo hacer violencia al objeto de estudio. Nuestra opción será entonces no renegar de una exposición en términos académicos, pero reconociendo en cada caso la violencia que con esto efectuamos al texto adorniano y a la idiosincrasia de su pensamiento. Presentaremos entonces las tesis de Adorno tal como nos impactaron: como portadoras de una fuerza crítica que nos lleva a considerar que lo que tienen para aportar a nuestras inquietudes justifica la violencia a la que aludimos.

Ahora bien, en lo que atañe directamente al contenido teórico de nuestro trabajo conviene también hacer algunas precisiones. Adorno no construyó algo así como una teoría del sujeto, ni nunca sistematizó una obra en el que tal concepto fuera el centro de la argumentación, por lo que el trabajo mismo de su exposición constituirá una apuesta de interpretación desde el comienzo. Esa libertad con respecto a la letra nos obligará a dividir la crítica al sujeto en dimensiones que responden a nuestros objetivos específicos. Esperamos asimismo que esta decisión quede justificada en el curso de nuestro trabajo. La presente tesis se compone entonces de tres capítulos en los que pretendemos discutir tres momentos de la crítica al sujeto adorniana, de modo que quede visible su estrecha relación con el imperativo categórico pos-Auschwitz.

Capítulo I: El primer paso será indagar al sujeto según una historia evolutiva de la especie en el marco de una relación cultura-naturaleza. Aquí veremos cómo Adorno 
comprende al sujeto como una herramienta de autoconservación, consolidado sobre instancias de represión de las pasiones y las disposiciones afectivas en función de un dominio cognitivo y práctico de la naturaleza. Este primer momento de la crítica, que aquí llamaremos "historia natural", nos dará también acceso al contenido normativo que ese sujeto posee, de modo que podremos avizorar en el mismo ciertas exigencias que la subjetividad contiene y que permitirían pensar otra relación entre los hombres y la naturaleza dominada.

Capítulo II: En este segundo capítulo diferenciaremos otra dimensión de la subjetividad, en la que un sujeto enfrentado con un objeto en el acto cognitivo reproduce las relaciones de identificación y represión por sobre toda externalidad. Lo fructífero de este segundo momento es que nos permitirá indagar en el modelo cosificado de experiencia que abriga dicha subjetividad. Ya no se tratará de la crítica a un sujeto enfrentado a la naturaleza, sino a un sujeto cognitivo enfrentado a un objeto de conocimiento. En este capítulo veremos cómo el sujeto se construye sobre relaciones de identificación y represión con todo lo exterior a su propia estructura pero, al mismo tiempo, mostraremos cómo es posible pensar un modelo ampliado de experiencia como enriquecimiento del conocimiento más allá de lo simplemente cognitivo.

Capítulo III: El problema de la cosificación de la experiencia planteado en el capítulo anterior nos permitirá encarar esta última etapa de nuestro recorrido. En este capítulo intentaremos ver en qué medida el antisemitismo puede ser comprendido como una forma de darse históricamente de la subjetividad analizada en los capítulos anteriores. Para esto enmarcaremos el análisis del antisemitismo en el contexto del fracaso histórico de la figura burguesa del individuo en las sociedades del capitalismo tardío. Veremos entonces que Adorno entiende este fenómeno en términos de un sujeto dañado en su capacidad experiencial $y$ en el que toda relación con un otro se efectúa como proyección/esquematización. También intentaremos dar cuenta de las correspondencias conceptuales que este análisis nos permite establecer entre antisemitismo, modernidad y totalitarismo. Al final del capítulo ofreceremos un apéndice en el que nos propondremos diferenciar la posición de Adorno de la de Jürgen Habermas con respecto a la relación modernidad-violencia y la superación del pasado reciente. 
En este recorrido dejamos afuera tópicos importantes de la filosofía adorniana, o al menos decidimos tratar algunos de ellos de manera lateral y no con la relevancia que se merecen, tópicos que son sumamente relevantes en los intereses de Adorno y también en el marco de la discusión sobre su crítica al sujeto; así quedaron afuera de nuestros intereses centrales sus reflexiones sobre la industria cultural, las críticas al cientificismo que realizó a lo largo de su vida, sus observaciones sobre la obra de arte, la importancia de la composición musical, los aspectos más metodológicos de su obra, su discusión con Heidegger, etc. Esta ausencia, estuvo motivada principalmente por una cuestión temática, ya que nuestra intención es discutir directamente los vínculos entre subjetividad y violencia histórica en relación con el imperativo categórico pos-Auschwitz. Sin duda, tal opción no está exenta de arbitrariedad de nuestra parte, pero esa arbitrariedad está condicionada por las necesidades de extensión, expositivas y críticas de nuestros objetivos. Consideramos así que el recorte realizado es enteramente funcional a los objetivos planteados y que es allí donde tal arbitrariedad encuentra su justificación. Nos consideramos autorizados a ordenar el trabajo de la forma en la que lo hicimos en la medida en que no existe una obra o un texto en el corpus adorniano que formule de forma explícita una teoría del sujeto, pero sabemos, al mismo tiempo, que dicho problema atraviesa nuclearmente cada texto suyo. 


\section{HISTORIA NATURAL}

En este primer capítulo comenzaremos nuestra lectura de la crítica adorniana al sujeto enmarcando ese concepto en una relación cultura-naturaleza. Esto nos mostrará tal concepto como atravesado por una serie de represiones y sacrificios ejercitados en función de una autoconservación antropológica; y el sujeto será entendido así como una instancia en la lucha por la supervivencia. Pero este análisis también nos permitirá ver la característica normativa que este concepto de sujeto posee en tanto se puedan plantear ciertas exigencias morales a partir de él.

Este primer enfoque del problema de la subjetividad nos permitirá entender las condiciones sobre las que se forjó esa conciencia cosificada y ese contexto de frialdad al que aludimos en la Introducción: resumidamente, en tanto herramienta de autoconservación el sujeto sólo pudo asumir una actitud fría y manipuladora para con la realidad y para consigo. Pero veremos que será también la figura civilizatoriamente creada del sujeto la que nos permitirá pensar la posibilidad de otra clase de relación intersubjetiva. Esta visión dialéctica del sujeto que aquí obtendremos -el sujeto como el producto de represión y como portador de un contenido de verdad moral- nos permitirá particularizar la crítica adorniana en el marco de otras críticas filosóficas al sujeto enarboladas durante el siglo XX.

Comenzaremos exponiendo el programa de historia natural y su posible relación con una crítica al sujeto (1), esto nos permitirá analizar tal concepto en su relación con la reproducción material de la vida y la autoconservación de la expecie (2), pero este análisis recién podrá ser completado cuando nos enfoquemos en el concepto de autoconservación, que a nuestro entender es el mecanismo sobre el cual se construye la subjetividad según Adorno; este concepto nos permitirá diferencia el análisis adorniano del análisis de Habermas planteado en términos comunicativos (3). Hacia el final, intentaremos mostrar que este concepto de subjetividad también impone exigencias a ser consumadas, tal cosa se volverá más clara si comparamos el análisis del sujeto adorniano con el ofrecido por Althusser (4).

1.- La idea de historia natural 
Como vimos en la introducción, para hacer visible ese principio de frialdad que estructura la subjetividad de Auschwitz hay que problematizar esa idea de un sujeto autónomo encerrado en sí mismo e impermeable al contacto su enterono. Por eso, lo primero que debemos encarar es el análisis de cómo se construye ese sujeto, y para esto retomaremos el concepto de "historia natural" que Adorno formulara muy tempranamente en su obra, concepto al que no vuelve a aludir sino mucho tiempo después, en Dialéctica Negativa, pero que, no obstante, señala un conjunto de preocupaciones que recorre toda su obra, y que en el marco de nuestros objetivos adquiere una singular relevancia.

Para comenzar debemos especificar qué entiende Adorno por Naturgeschichte para ver en qué medida ese concepto puede funcionar como una crítica a la "ideología del sujeto". En una célebre conferencia de 1932 llamada justamente "Die Idee der Naturgeschichte" Adorno había diagramó un programa de filosofía interpretativa en el que ese concepto era utilizado en un sentido crítico: se trataba de emplear un "procedimiento (Verfharen) que permitiera interpretar la historia concreta en sus propios rasgos como naturaleza, y hacer dialéctica a la naturaleza en la figura de la historia (Zeichen der Geschichte)" "[AF: 160] (AF: ). Lo que el programa de la Naturgeschichte busca es organizar la mirada filosófica de modo tal de formar "constelaciones" (Konstellationen) ${ }^{3}$ de

3Conviene realizar algunas observaciones sobre este concepto que tiene cierta importancia en la obra adorniana. Para Adorno el uso del lenguaje cotidiano es un ejemplo de pensar constelativo ya que "este no ofrece un mero sistema de signos (Zeichensystem) a las funciones cognitivas. Allí donde se presenta esencialmente como lenguaje, donde se vuelve representación, no define sus conceptos. A éstos su objetividad se procura por medio de la relación en que pone a los conceptos, centrados en torno a una cosa" [ND: 164] (DN: 165). Este concepto de constelación Adorno lo toma de Benjamin, pero no sin cierta actitud crítica. Benjamin en la "Introducción Epistemológica" al Origen del Drama Barroco Alemán decía lo siguiente: "las ideas son a las cosas lo que las constelaciones son a las estrellas. Esto quiere decir, antes que nada, que las ideas no son ni las leyes ni los conceptos de las cosas. [...] Las ideas son constelaciones eternas y, al captarse los elementos como puntos de tales constelaciones, los fenómenos quedan divididos y salvados al mismo tiempo. (1990: 17).

Una diferencia importante entre el concepto benjaminiano de constelación y el adorniano es que para Adorno la constelación no es posible sin los elementos que la constituyen, no es nada en sí mismo sino una relación temporalmente constituida entre elementos particulares. Es decir, que el concepto de constelación no tendría ese carácter metafísico que parece poseer en Benjamin, sino que es un modelo que el crítico forja y que está determinado por la situación en la que tiene lugar (Jarvis, 1998: 176). En Adorno la idea de constelación tiene un sentido más bien metodológico similar a lo que Weber entiende por "tipos ideales" en tanto modo de construir los conceptos; así en La Ética Protestante y el Espíritu del Capitalismo Weber afirma que la conceptualización "tiene 
objetos en el que la apariencia ideológica de ciertos artefactos culturales quede develada. En Adorno la constelación es un procedimiento que se opone a la argumentación deductiva que pretendía avanzar a partir de un concepto general. Por el contrario, el análisis constelativo encontraba su fuerza en rodear la cosa a partir de conceptos heterogéneos pero sin intentar definirla taxativamente. Es con ayuda de esta experiencia como construye y "deconstruye" el concepto de sujeto como veremos en este capítulo.

En Adorno la Naturgeschichte consiste en un procedimiento crítico que opera con las instancias temporales de lo arcaico y lo moderno en un juego dialéctico y desfetichizante: la crítica, efectuada como Naturgeschichte, debe tomar un determinado objeto cultural y reconocer en él tanto la novedad de su aparición como la antigüedad del proceso del que formaba parte. Por ejemplo, si consideramos que una estrategia ideológica consiste en la naturalización de lo histórico es decir, en otorgarle un carácter no determinado y valido para todo tiempo y lugar a fenómenos concretos (por ejemplo, decir que siempre existió el capitalismo y que por ende es natural, o que la subjetividad está inserta en los genes, etc.), la Naturgeschichte debe entonces remover eso así solidificado y mostrarlo como contingente y creado. Por el contrario, si la estrategia ideológica consiste en disfrazar de contingente lo necesario, en presentar como fruto del azar lo que es condición estructural (por ejemplo: presentar a la explotación como fruto de una opción personal y moral, y no como radicada en la misma estructura social), en este caso la Naturgeschichte debe mostrar los fenómenos como siempre ya presentes en la civilización, como fenómenos estructurales.

Esto queda patente cuando Adorno introduce el concepto de "segunda naturaleza (Die zweite Natur)" tomado de Lukács ${ }^{4}$ (1973: 356) para designar el conjunto de relaciones que ajustarse a o elaborarse con una serie de elementos encontrados en la realidad de los hechos históricos. Esta es pues la razón por la cual no podemos dar como concluyente la determinación conceptual desde los inicios de la investigación, sino hasta que lleguemos al final de ella" (2003: 37). De modo que, la idea de composición o elaboración de los conceptos, por contraposición a una imposición de conceptos previamente forjados, es lo que Adorno entiende por constelación (ND: 168; DN: 169). La analogía entre "tipo ideal" weberiano y "constelación" adorniana es analizada por Axel Honneth (2009: 69-72).

4El concepto de "segunda naturaleza" estaba presente en la Teoría de la Novela (1914), con él Lukács describía un "mundo de las convenciones" en el que se hace patente "la desaparición de todo fin evidente, la desorientación decisiva de la vida entera", un mundo cuyas leyes "se imponen con una necesaria evidencia al sujeto conocedor pero que, no obstante, no ofrece un sentido al sujeto en busca de su fin, ni un campo de actividad inmediatamente sensible al sujeto actuante" (Lukács:60). En la modernidad Lukács diagnosticaba la desaparición de la unidad de la cual ya no 
reificadas que constituyen el mundo social actual. Ante esto, la tarea de la Naturgeschichte era devolver los objetos naturalizados a su aspecto histórico y, al mismo tiempo, mostrar que en el presente operan elementos estructurales. La obviedad de la tradición con la que ideología se nos impone en nuestra vida práctica es remitida por la Naturgeschichte a su proceso de configuración histórico $\mathrm{y}$, de este modo, abre la perspectiva de su transformación; esto implica no pensar la historia como determinación del ser, sino como contingencia; y por otro lado, posibilita también que la novedad histórica se muestre como ya arraigada en el mito, como parte estructural de la civilización -lo que implica no pensar la historia como absoluta contingencia, sino como un proceso con continuidades-. Este ejercicio no es un motivo aislado en la obra de Adorno, como lo demostró, en su influyente y clásico ensayo, Susan Buck Morss al argumentar que toda la filosofía adorniana estuvo atravesada por el temprano programa de Naturgeschichte. Fue bajo esa hipótesis que Buck Morss hilvanó de forma muy convincente los aspectos metódicos escondidos en la obra de Adorno:

historia y naturaleza en tanto opuestos dialécticos eran para Adorno conceptos cognitivos, no demasiado diferentes de las ideas regulativas de Kant, que se aplicaban en sus escritos como herramientas críticas para la desmitificación de la realidad. (1981, 112).

De modo que, la utilización dialéctica de los conceptos de historia y naturaleza que Adorno efectuaba mediante su Naturgeschichte provocaría que el objeto ideológicamente fetichizado se abriera en un "campo de fuerzas (Kraftfeld)" [NL: 53] (NL: 23). -tomando prestado un término que aparecerá un poco más tarde en la obra de Adorno- y los dejara disponibles para una realización futura de su rescate. Entonces, la crítica debería tomar sus objetos y configurarlos buscando ese "campo de fuerza" en el que la "dialéctica histórica" que se halla contenida quede expuesta al pensamiento racional. Sobre este punto en el mismo trabajo Buck Morss afirma:

era lícito ningún rescate de carácter heroico u honorable, y que era lo que la novela moderna reflejaba. En ese contexto "la segunda naturaleza, la de las relaciones sociales, no posee ninguna sustancialidad lírica; sus formas son demasiados rígidas para adaptarse al instante creador de símbolos", es nada más que "la petrificación de un complejo de sentido que se ha vuelto extraño, inapto, de ahora en adelante, para despertar la interioridad; es un osario de interioridades muertas" en Teoría de la Novela, ed. Siglo XX, Bs. As., 1966. Adorno asume este concepto de "segunda naturaleza" para describir el mundo como cosificado, pero sin el patetismo y el carácter de lamentación que tiene en Lukács, sino como una situación histórica y existencial que la crítica debe abrir, así en su Idea de la Historia Natural afirma: "el problema de la historia natural se plantea para empezar con la pregunta de cómo es posible aclarar, conocer ese mundo enajenado, cosificado, muerto" de la segunda naturaleza" [AF; 120] (AF 325) 
Cada vez que la teoría sostenía a la naturaleza o a la historia como primer principio ontológico, se perdía este doble carácter de los conceptos, y con él la potencialidad de negatividad crítica: o se afirmaban naturales las condiciones sociales perdiendo de vista su devenir histórico, o se afirmaba como esencial el proceso histórico real, y la sufriente materialidad que componía la historia era despreciada como pura contingencia (Hegel) o se ontologizaba como esencial en sí misma (Heidegger). (1981: 123).

La historia que le interesaba a Adorno en su crítica no era la historia empírica, sino la historia interior, la historia sedimentada que las formas ideológicas guardaban. A este respecto podemos considerar una distinción en dos niveles de análisis en los cuales es pensada la historia por Adorno: una "historia externa" de los acontecimientos empíricos, externa al pensamiento pero que guarda una relación mediada con este y, por otro lado, una "historia interna" concebida como un "devenir interno al pensamiento, a una obra de arte o a cualquier objeto de conocimiento". La crítica entonces debe rescatar como "historia interna" de sus objetos el "sentido de un momento histórico que permanece súbitamente adherido a las partes de un objeto aparentemente insignificante" (Sotelo; 2009; 27). Esa "historia externa" sólo tiene valor para Adorno como jalones o imperativos del pensamiento, pero siempre en una mediación con éste; este carácter imperativo de la historia externa se hace patente en la exigencia de que Auschwitz no se repita o en la sentencia que afirma que es un acto barbárico escribir poesía luego de Auschwitz. Pero en lo que está interesado Adorno es en la "historia externa" como traducción de una "historia interna" es decir, en la historia social sedimentada en los conceptos. Esta idea de rescatar la experiencia histórica que subyace a los objetos mediante una "filosofía interpretativa (deutender Philosophie)" [AP: 338] (AF 307) es una vuelta de tuerca sobre el problema marxista de la reificación y de la ideología, pero ahora en términos de la relación cultura-naturaleza ${ }^{6}$.

5 Sobre este punto es interesante el trabajo de Laura Sotelo en el que se intenta reponer la problematización de la Naturgeschichte en el contexto de la discusión llevada adelante en Frankfurt en 1929 por Max Scheller y Karl Mannheim en torno al carácter ontológico de los valores. Para Sotelo el problema de la Naturgeschichte en Adorno tendría su suelo "originario" en esa discusión mientras que el marxismo, la teoría estética o el psicoanálisis no serían sino "materiales fluyentes" en su pensamiento, "sobredeterminados" por aquel (2009, 29-30). Lo profundamente adorniano sería entonces una actualización filosófica de la ontología que diera cuenta de la ruptura al interior del Ser, y es esa ontología la que está en el fondo del programa de Naturgeschichte (Ibídem., 33).. 6 En este punto vale la pena observar que el concepto de Naturgeschichte aparece ya en los Manuscritos Económico Filosóficos de 1844 en un sentido similar al que tiene en Adorno: "La historia misma es realmente parte de la Historia Natural, el devenir hombre de la naturaleza" (Marx; 
Será en Dialéctica de la Ilustración, obra que Adorno escribiera junto con Horkheimer durante los años de guerra ${ }^{7}$, donde se desarrollarán las implicaciones de esta historia natural para una teoría del sujeto. La moraleja del relato que construye Dialéctica de la Ilustración puede ser resumida del siguiente modo: tal y como lo había afirmado Kant ${ }^{8}$ la racionalidad fue la instancia que posibilitó la salida del hombre de su "minoría de edad", salida que significó, en términos de la constitución de la cultura, la consumación de una autonomía humana por sobre el mundo de los mitos y la superstición. Pero esta autonomía en realidad se asentó fundamentalmente en el saber ejercitado como instrumento para afianzar el control del hombre sobre su entorno natural. Este ideal, que propiciaba ser los amos de la naturaleza mediante su desencantamiento, es lo que en la lectura de Adorno-Horkheimer subyace a todo el pensamiento occidental. Sin embargo, fue esta misma racionalidad, que había posibilitado el remplazo del mito por el sentido otorgado racionalmente, la que siguió un proceso de formalización creciente y neutralización de sus

2004; 152). Marx en lo Manuscritos rechazaba un concepto de historia como un principio ontológico y, a la vez, atribuye al par conceptual de naturaleza e historia un papel correctivo mutuo: la naturaleza no era el despliegue de un espíritu absoluto, ni la historia humana era el resultado de una pura naturaleza. Una lectura de este texto de Marx que recalca especialmente el papel normativo de esta Historia Natural la realiza Stephen Huber, para quien en los Manuscritos Marx tendría una posición "naturalista en la medida en que piensa que algo prexiste en el orden de los hechos sociales y culturales, algo de lo que continúa dependiendo fácticamente en parte ese orden y que también permite evaluar normativamente sus manifestaciones" (2008; 146).

7 Si bien Dialéctica de la llustración fue escrita conjuntamente por Adorno y Horkheimer, la responsabilidad en la redacción de los capítulos recayó más sobre uno u otro según cada caso. Pero como la mayoría de los intérpretes han puesto de relieve Dialéctica de la llustración representa una mayor continuidad con el pensamiento previo y posterior de Theodor Adorno que con el de Horkheimer. Por tal motivo vamos a tomarnos la libertad de atribuir en este trabajo las afirmaciones contenidas en ese escrito a la figura de Adorno, pero con la conciencia siempre que se trata de una obra mancomunada. ver Jay (1984: 413). Un estudio del proceso de producción de esta obra central en la tradición de la teoría crítica y de la importancia que los autores le daban a lo que ellos consideraban su "proyecto de la dialéctica", desde el plan inicial de Horkheimer hasta la centralidad de la mano de Adorno puede verse en Wiggershaus. (2010: 380-410).

8En la figura de Kant la ilustración se entendió a sí misma como la capacidad del hombre de servirse de su inteligencia "sin la guía del otro" y liberarse con esto de su "culpable incapacidad": "¡ten el valor de servirte de tu propia razón!; he aquí el lema de la llustración" en Kant (1945: 25). Con respecto a esto vale la observación de Friedman que resume en marcos generales la importancia de esta dialéctica de la ilustración como reflexión sobre la racionalidad: "El problema de la ilustración constituyó el punto de partida de la filosofía política de la Escuela de Frankfurt. [...] los frankfurtianos se dieron cuenta de que la lucha histórica entre razón y naturaleza constituía sólo el prefacio de la verdadera existencia humana. Únicamente con el triunfo de la razón podría el hombre vivir una vida enteramente humana". Pero "ésta época que debió haber sido la más humana y en la que la promesa de la llustración debió ser moneda corriente, era por el contrario, la más horrorosa. Su símbolo no fue la Novena Sinfonía de Beethoven, sino Auschwitz" (Friedman, 1986: 117). 
aspectos críticos para caer, finalmente, en un estadio histórico caracterizado por un retorno de las fuerzas míticas como violencia y dominio en el presente.

En ese marco lo que la Naturgeschichte pretendía plantear era el viejo problema filosófico de la relación sujeto y objeto, pero colocándolo dialécticamente en el marco de la relación cultura-naturaleza. Tal cosa Adorno la efectúa restituyendo la objetividad, como naturaleza reprimida, a un sujeto que pretende ideológicamente autonomizarse. Es decir, cumple la tarea de restituir el sujeto a su objetividad, y lo hace insertando la figura reificada de la subjetividad en el marco en una relación dialectizada entre cultura y naturaleza. Sólo de ese modo, confiaba Adorno, el sujeto podría salir de la ilusión de su propia autonomía, de su encantamiento ideológico. Veamos cómo se lleva a cabo tal cosa.

\section{2.- El sujeto como naturaleza}

Es en el excurso sobre la Odisea de Homero en Dialéctica de la Ilustración donde se construye alegóricamente la crítica a la ideología del sujeto en el marco de una Naturgeschichte. En esa sección del libro, titulado “Odiseo, mito e ilustración”, el concepto de sujeto será presentado como el resultado de una tensión con lo biológico. El relato es más o menos el siguiente: el ser vivo, en un esfuerzo por mantener su existencia, debe moverse en un entorno natural que se le presenta como amenazante e infinitamente más fuerte; este viviente no es en absoluto diferente de ese medio ya que vive en estado de plena indiferenciación; entonces, para no ser devorado por el entorno biológico el viviente comienza a forjar las herramientas que van a permitir su autoconservación y su progresiva diferenciación -en un comienzo relativa, hacia el final absoluta- de ese entorno natural. Será en este marco en que Adorno estudiará la subjetivación y la consolidación de una racionalidad autónoma. La autoconservación es realizada mediante una estrategia de renuncia a la satisfacción inmediata en pos de la preservación de su vida, en la medida en que vea como mucho más peligroso la disolución de la muerte que el sacrificio que debe realizar. Es este mecanismo de renunciamiento sistemático el que terminará perpetuándose para Adorno como estructura de una subjetividad reificada, y es lo que se encontrará por debajo de toda autoconservación antropológica. 
Es aquí donde Adorno inserta la lectura de la Odisea como una interpretación filosófica de ese proceso de subjetivación o "prehistoria de la subjetividad" (Urgeschichte der Subjetivität)" [DA: 72] (DI: 107). En esta lectura Adorno no construye una "robinsoneada", sino que intenta pensar un modelo hipotético que permita vislumbrar los diferentes mecanismos implicados en tal proceso - por lo demás Odiseo se desenvuelve siempre en un mundo ya poblado por mitos, en un mundo que ha sido mediado por el lenguaje y los relatos de sentido, es decir un mundo ya intersubjetivamente habitado-. En el relato, Homero da cuenta de las peripecias de Odiseo en su regreso a Ítaca, en el que debe afrontar diversos peligros y tentaciones a lo largo del camino, pero el héroe imperturbable se mantiene fiel a su plan original y con astucia y racionalidad guía a su tropa de regreso a la tierra añorada. En la lectura de Adorno, el relato representa las dificultades que debe atravesar el yo para constituirse como una instancia autónoma sobre un mundo poblado de mitos y sobre una naturaleza amenazante y seductora a la vez. Cada aventura representa una amenaza para la lógica del sujeto, una tentación de desviarse y perder la identidad; Odiseo debe abandonarse a esas fuerzas para luego rescatarse y, de ese juego de idas y vueltas con lo múltiple y diverso, y sólo así obtiene su "unidad sólo en la diversidad de aquello que niega la unidad" (Einheit bloß in der Mannigfaltigkeit dessen, was jene Einheitverneint) [DA: 66] (DI: 100).

Pero de lo que aquí se trata es del momento en el que esos relatos producen un desplazamiento para comenzar otro relato, que se apoya sobre premisas diferentes. No debemos entender esto como una cronología en la que primero hubo pensamiento arcaico y luego racionalidad, sino que lo que Adorno y Horkheimer pretenden demostrar, y en eso consiste el conjunto de reflexiones que constituyen su Dialéctica de la Ilustración, es que ese relato de la racionalidad no es tan distinto del relato mítico tal y como se suele considerar. En definitiva, lo que muestra esta lectura no sería tanto el surgimiento de la racionalidad como instancia nueva, sino la autonomización de un tipo determinado de racionalidad, una racionalidad instrumental, que ya estaba incipientemente contenida en el pensamiento mítico: podemos decir entonces que lo nuevo no es la racionalidad ni el sujeto, sino el proceso mediante el cual una forma de racionalidad, es decir, una forma de relación del sujeto con respecto a una objetividad toma primacía sobre otras posibles. Como dijimos, la Naturgeschichte no pretende ofrecer una secuencia histórica, ni plantearse una 
robinsoneada que intente pensar un primer hombre, sino pensar la relación de dos elementos que parecían estar separados -en este caso el concepto de racionalidad y el concepto de naturaleza- para de este modo criticar la entronización de una forma de racionalidad particular por sobre las otras. Es así como también lo entiende Simon Jarvis para quien:

“la explicación de la ‘ilustración’ [...] no es la explicación de un período histórico, sino un intento de descifrar la prehistoria de nuestra propia racionalidad instrumental que prosigue sin la mínima consideración de su objeto" (1998: 26, la traducción es nuestra).

Entonces debido a este interés, la lectura de La Odisea como documento esencialmente moderno significará para Adorno que el sujeto y la racionalidad son instancias que guardan una relación estrecha con lo natural, pero que en determinado momento comienzan a perfilar ciertas formas y figuras que van a postular una autonomía ficticia, ya sea como razón instrumental o como sujeto omnipotente. Wiggershaus reconoce esta discusión cuando afirma que:

la genialidad con la cual Adorno propondría nuevas facetas en un texto clásico que había sido ya interpretado muchas veces se demostró sobre todo en que reveló claramente el precio de la Ilustración este, de acuerdo con Horkheimer, primer documento de la antropología del ser humano, en sentido moderno de un ser racionalmente ilustrado. (2004: 414)

De modo que, en la medida en que el texto sea leído "en sentido moderno de un ser racionalmente ilustrado" las peripecias de Odiseo en su regreso a Ítaca se nos mostrarán como el relato del camino de la racionalidad sobre la multiplicidad de los mitos y, al mismo tiempo, como el relato de la consolidación del yo como instancia autónoma. Esta "protohistoria de la subjetividad" devela entonces a la identidad del yo como una función de la represión sobre lo no idéntico, lo disperso y disolvente de lo natural. Lo que Adorno pone en juego aquí es un concepto de sujeto en el que se acentúa su implicación con el ámbito natural, en un análisis claramente freudiano centrado en la tensión entre esa instancia autónoma, en la que se convierte el sujeto, y un origen material que debe ser continuamente reprimido.

El marco en el que Freud piensa la relación de los hombres con sus ilusiones sociales en el Porvenir de una Ilusión (1927) le sirve a Adorno aquí como esquema para pensar la civilización. En ese texto Freud estudiaba el origen de la ilusión religiosa en el contexto de una relación con la naturaleza, en la que la civilización era entendida como 
aquello que nos protegía y nos permitía subsistir por sobre una naturaleza amenazante ya que:

“...suprimida la civilización, lo que queda es el estado de naturaleza, mucho más difícil de soportar. Desde luego, la Naturaleza no impone la menor limitación a nuestros instintos y nos deja obrar con plena libertad; pero, en último término, posee también su modo especial de limitarnos: nos suprime, a nuestro juicio, con fría crueldad, y preferentemente con ocasión de nuestras satisfacciones." (Freud, 1988: 2967)

Para Freud la civilización es tanto la que posibilita la subsistencia del individuo como la que causa sus malestares ya que "le impone determinadas privaciones" que ocasiona "cierta medida de sufrimiento, bien a pesar de los preceptos de la civilización, bien a consecuencia de la imperfección de la misma" (ibídem.; 2968). En la metapsicología freudiana el sujeto está planteado en un antagonismo entre las exigencias pulsionales y las restricciones impuestas por la cultura, de modo que a medida que la cultura va reprimiendo el desarrollo de las pulsiones sexuales y agresivas estas van interiorizándose y transformándose en conciencia moral como Super-yo. En El Malestar de la Cultura (1929-1930) Freud afirma que "cuando un impulso instintual sufre la represión, sus elementos libidinales se convierten en síntomas, y sus componentes agresivos, en sentimiento de culpabilidad" (1988: 3062), esto ocurre debido a las cargas de agresividad liberadas sobre la conciencia en forma de preceptos morales de imposible cumplimiento. Esta es la causa de los fenómenos de "malestar cultural": ansiedades, depresiones, etc. Este planteamiento en términos de pulsiones y represiones culturales ya estaba presente en Más Allá del Principio del Placer (1920), donde Freud había introducido el concepto de "pulsión de muerte" como una pulsión inherente a todas las formas de vida orgánica que busca restablecer un estado anterior a la vida, y que actuaría en contraposición a una "pulsión de vida" que se manifestaría como tendencia a la unidad y la coherencia del ser vivo (Freud; 2008). Esta ambivalencia es la que se deja ver en el fondo del análisis cultural adorniano entre autoconservación y tendencias a la disolución, y es la que se toma como marco para esta problematización del sujeto.

Para apreciar mejor los contornos de la propuesta adorniana cale considerar brevemente la obra de Marcuse, quien en su Eros y Civilización (1954) diagnostica una dialéctica de la civilización en términos muy similares a los de Adorno. También a partir de Freud, Marcuse entenderá la historia en el marco de una dinámica pulsional entre el 
impulso de muerte (Tánatos) y el impulso de vida (Eros). Con esto Marcuse pretende identificar "ciertas tendencias básicas en la estructura instintiva de la civilización y, específicamente de definir el principio de realidad específico que ha gobernado la civilización occidental" (Marcuse, 1985: 127). En esta reconstrucción el progreso civilizatorio se realiza a costa de un aumento de la sublimación y control de los instintos, pero esto ocasiona a su vez un debilitamiento de los instintos eróticos y sexuales disolventes, es decir una represión del Eros en función de los requisitos de productividad. El problema con esto es que genera, por un lado, cuotas altísimas de sufrimiento y malestar y, por otro lado que, al quedar Eros debilitado, los impulsos destructivos quedan liberados; esto es lo que Marcuse denomina "retorno de lo reprimido" y que es una vuelta de lo que Adorno y Horkheimer denominan "rebelión de la naturaleza". De ese modo, para Marcuse el progreso era contra-actuado por un impulso de muerte en una dialéctica entre "racionalidad y destrucción" (Ibídem.: 107).

Para explicar las patologías sociales que esto provoca Marcuse introduce el concepto de represión excedente (surplus repression), con el cual aludía a los controles adicionales que salen de las instituciones involucradas en los mecanismos de reproducción social y "las restricciones provocadas por la dominación social". Esta es distinta a la represión básica que son las "modificaciones de los instintos necesarias para la perpetuación de la raza humana en la civilización" (Ibídem.: 46). Es decir, la surplus repression es necesaria a los fines productivos en un momento en el que la sociedad puede autoreproducirse sin necesidad de ella ${ }^{9}$. Para Adorno como para Marcuse el modelo

9 Ejemplos de esta represión es la subyugación de la sexualidad a su función procreativa y su encuadramiento en la relación monogámica, también la "unificación de los instintos parciales" como el gusto o el olfato en pos de instintos sexualmente menos intensos como la vista o el oído son ejemplos de este mecanismo represivo. Si bien el modelo de individuo marcusiano posee un dinamismo intrapsíquico mayor que el adorniano, referirse a este análisis deja mejor en claro a qué se está aludiendo con esta dialéctica hombre naturaleza.

Para Wiggershaus Eros y Civilización es la Dialéctica de la llustración de Marcuse (2010: 621) aunque la recepción que despertó aquella obra en Adorno y Horkheimer estuvo lejos de ser entusiasta debido a lo que consideraban un "estilo directo" o no mediado de la obra (Ibidem.: 623). Con respecto a esto Wiggershaus ofrece una interesante lectura. Para él en este texto Marcuse plantea algo que Adorno a lo largo de toda su obra renunció a plantear el problema de la fundamentación de la teoría crítica, es decir, los criterios que el teórico asume para diagnosticar un estado de cosas como malo o deformado. Marcuse poseía ciertamente la confianza en una estructura pulsional "buena" (el Eros) que debía de ser liberada para rencauzar los males civilizatorios (ibídem.: 185-206), es decir existía la apelación a una instancia existente pero reprimida como base normativa desde la cual ejercer la crítica. Esta asunción positiva de una base normativa es según Wiggershaus lo que se encontraba cuestionado detrás de la acusación de un "estilo directo" por parte de Adorno. Dice Wiggershaus al respecto: “¿Con ello (con la apelación a 
freudiano permitía pensar un concepto de sujeto basado en un sistema de represiones y privaciones que provocaban efectos sociales patológicos. Vemos así como el modelo de sujeto agresivo y a su vez dañado en su capacidad de abrigar placer ya está planteado en este modelo de análisis.

Este análisis del origen natural del sujeto lo veremos más claramente en el pasaje en el que Adorno lee el relato de Odiseo con las Sirenas: el héroe debe atravesar el muelle en el que las Sirenas amenazan con perder al viajero mediante la seducción de su canto ofreciéndole la "irresistible promesa de placer" (DA: 49; DI; 86) que provocaría su desventura y el abandono de su meta. El peligro de la perdición representado por el canto de las Sirenas es tanto el peligro de la muerte como el peligro del placer disolvente; ambas representan instancias que el sujeto debe sortear si quiere conservarse. Ante esto, Odiseo elabora un plan para sustraerse de este peligro: les tapa los oídos con cera a sus remeros y ordena remar sin detenerse, mientras él se hace atar a un mástil pero con los oídos liberados; de este modo, impotente en sus movimientos escucha el canto de las Sirenas pero neutralizando la tentación de perderse con ellas. Este breve relato representa para los autores el afianzamiento del sujeto por sobre el placer que promete la naturaleza no domesticada, puesto que: “el héroe, a quien se dirige dicha seducción, en el sufrimiento se ha convertido en adulto. En la variedad de los peligros mortales, en los que hubo de mantenerse firme, se consolidó la unidad de su propia vida, la identidad de la persona” [DA: 49] (DI; 85). El sujeto racional, que sopesa los peligros y que dispone las condiciones

una estructura pulsional que debía ser liberada) no se había puesto a discusión finalmente sin ambages aquello en lo que también Horkheimer y Adorno -solamente de manera indirecta, avergonzadamente, de manera aforística- se apoyaban: el hecho de que desde la naturaleza, pasando por el mito, hasta llegar a la ilustración y a la razón, había una valoración positiva que se fundaba a final de cuentas en un sentimiento espontáneo, y por ello natural, para lo correcto, lo bueno, lo verdadero?" (Ibídem.: 629).

Para Marcuse los elementos para establecer una distinción entre una buena naturaleza y una mala y para la consumación de una sociedad no represiva estaban siempre presentes en el orden existente como estructura pulsional todavía sofocada. Por el contrario el negativismo adorniano boicoteaba constantemente esta posibilidad y evitaba, con eso, la fundamentación de la crítica o la apelación a una instancia histórica puntual desde la cual encauzar una praxis de transformación. Para Wiggershaus, al negarse a discutir el texto de Marcuse, Adorno estaba reprimiendo una discusión que se había planteado en los comienzos de la teoría crítica, es decir la discusión por los fundamentos de tal teoría. Era notorio que Adorno renunciaba a toda garantía en una historia subterránea, y sólo confiaba en una negatividad consumada de forma radical, negatividad que sólo podía ser planteada en términos teológicos y no históricos según Wiggershaus. Esta "teología oculta" fue lo que impidió una recepción adecuada del libro de Marcuse, y estaba en línea con la estrategia de "mantenerse oculto y no presentar como un cimiento tangible y seguro el centro desde el cual filosofaba" (Ibídem.: 635). 
para la supervivencia, sería entonces la herramienta que se va forjando civilizatoriamente para no perecer ante el peligro de la naturaleza.

Pero la lectura adorniana del mito de Odiseo y las Sirenas dice un poco más. En la constitución de esa subjetividad se da una división entre el placer y el trabajo, y ambas instancias quedan separadas como esferas distintas de la praxis social en función del mantenimiento y la reproducción material. Esta observación tiene, por supuesto, notorias semejanzas con la dialéctica del amo y del esclavo hegeliana, semejanzas que se hacen evidentes en lo que respecta a la constitución de los sujetos sobre la división social del trabajo, y con las disposiciones subjetivas que van aparejadas. Los remeros deben trabajar pero con los oídos tapados no pueden percibir la belleza del canto de las Sirenas, mientras que Odiseo liberado de la carga laboral siente el encanto de las Sirenas, pero el orden social que él ha forjado lo confina a permanecer en la impotencia de un simple espectador. Sin embargo, se trata de una dialéctica cuya resolución, a diferencia de la hegeliana, radica en la solidificación de ambos términos, y no en la disolución de la fijeza de la conciencia como en Hegel (2007: 119). El remero-esclavo reproduce en su vida la del opresor, mientras que los lazos sociales mantienen el encanto de la belleza lejos de la praxis laboral, o sólo la ofrecen neutralizada como patrimonio cultural; así al final de esa aventura:

el goce artístico (Kunstgenuß) y el trabajo manual (Handarbeit) se separan en su despedida de la prehistoria (Vorwelt) [...] El patrimonio cultural se halla en exacta correlación con el trabajo forzado, y ambos tienen su fundamento en la inevitable presión hacia el dominio social sobre la naturaleza "[DA: 52] (DI: 87)

En esta lectura el poema homérico nos muestra que, por un lado el sujeto se constituye sobre el sacrificio del placer y del momento sensible que lo habita; mientras que, por otro lado, esa constitución tiene como correlato la separación del trabajo social del mundo del placer, y con ello una escisión que se reproduce al interior del sujeto: el trabajo productivo autonomizado por un lado, y el reino de los goces neutralizados como arte o cultura por otro. El orden social asentado sobre la realización laboral y sobre la disposición instrumental de las cosas queda separado como esfera aislada de la dimensión de las emociones y el placer. Para Adorno en el origen del domino se encuentra la división social entre el trabajo manual y el trabajo intelectual. En esa escisión las funciones quedan compartimentadas y la esfera del trabajo comienza a reproducirse desprovista de goce, que quedará posteriormente neutralizado como cultura o arte. 
Pero a diferencia de Adorno, para el Hegel de la Fenomenología "el trabajo [...] es apetencia reprimida, un desaparecer detenido, es decir, el trabajo forma" (2007: 120); si bien el trabajo tiene el sentido negativo de ser una renuncia a la satisfacción inmediata y al goce en la destrucción del objeto, justamente por esta renuncia adquiere un sentido positivo en tanto convierte al hombre en un ser universal. Condición de esta universalidad para Hegel es que ese trabajo sea realizado sobre experiencias humanas auténticas: en el trabajo el esclavo objetiva el temor y en esa misma acción humaniza el mundo. En Hegel ese trabajo consumado mediante una renuncia a una satisfacción inmediata es lo que otorga al hombre una universalidad que de otro modo no tendría, es lo que lo diferencia de la animalidad y abre la posibilidad de goces más humanos, es “el puro ser para sí de la conciencia, que ahora se manifiesta en el trabajo fuera de sí y pasa al elemento de la permanecía” (Op. Cit.). Sólo en el trabajo el hombre encontrará su universalidad y podrá saberse independiente del mundo natural.

De forma similar, para el Marx de los Manuscritos la universalidad del hombre radicaba en que a diferencia del animal que produce sólo bajo coacción de la necesidad física inmediata, "el hombre sabe producir según la medida de todas las especies [...] el hombre forma por ende de acuerdo con las leyes de la belleza" (Marx, 2004: 113). El trabajo es para Marx lo que confirma la universalidad que el hombre posee como ser genérico, es la "objetivación de la vida genérica del hombre" en el que la naturaleza aparece como "obra y realidad del hombre". Sin embargo, si bien el hombre realiza su actividad genérica en el trabajo, en el contexto de producción capitalista el obrero es obligado a vender su fuerza de trabajo y es desposeído de su producción, de este modo esta actividad se le vuelve la causa de una serie de alienaciones que lo convierten otra vez en un ser biológico.

Entonces, si para Hegel el trabajo es la universalización del hombre, para Marx el trabajo es la objetividad de una universalidad que el hombre ya posee como "ser genérico" (Gattungwessen); pero en ambos casos se encuentra una correspondencia entre universalidad y trabajo que se hace manifiesta a partir de la escisión entre la actividad humana del trabajo y la simple actividad biológica ${ }^{10}$. Pero Adorno no parece compartir ese

10 Conviene aclarar que ni en Hegel ni en el Marx de los Manuscritos hay una deriva hacia un productivismo asentado en una perspectiva acrítica del trabajo. En Marx eso es patente ya que la categoría de "trabajo alienado" tiene una notoria centralidad en los Manuscritos. Igualmente en la Fenomenología en la "dialéctica del amo y del esclavo", antes de arribar a su humanización 
sentido ontológicamente positivo que el trabajo tendría para el sujeto, por lo que replantea los términos de la relación trabajo-universalidad humana. Para él, el trabajo en la medida en que sólo se aboca a los fines de la reproducción social es trabajo alienado socialmente despojado de placer. Esta forma de vincular trabajo y autoconservación sin placer nos muestra que el concepto de alienación en Adorno es más amplio que en Marx, es disociación de la naturaleza y el placer en la génesis de toda actividad productiva, y no sólo disociación de los productos del trabajo de la mano del productor. Por este motivo Adorno no va a buscar una universalidad potencial en el trabajo que posibilite una forma ampliada de racionalidad, una liberación del sujeto o la consumación de un proceso de desalienación, porque, en la medida en que el trabajo social productivo esté dirigido a los fines de la autoconservación social, éste deberá despojarse de su origen vital, deberá suprimir los rasgos de placer y con esto amputar sus elementos potencialmente liberadores para devenir en una instancia de dominación social.

Pero que el trabajo siempre haya estado ligado a los fines de la autoconservación de la especie, y por eso escindido de toda gratuidad, no significa que esa vinculación sea ontológica, sino que se trata más bien una vinculación que se dio en la forma de desarrollo civilizatorio. Ante esto "solamente la astuta combinación de trabajo y felicidad puede dejar abierto el camino a la auténtica experiencia bajo la presión de la sociedad" [MM: 148] (MM: 130), lo que nos llevaría a pensar un sentido positivo del trabajo. Pero esta separación entre placer y obligación, entre trabajo y felicidad se impone como norma en todo orden social debido a la necesidad de asegurar su reproducción, y es esta escisión lo que se inserta en la fisonomía del individuo como frialdad en el cumplimiento de las funciones.

En la lectura de Adorno, Odiseo constituye también la anticipación del individuo burgués, quien como empresario previsor lleva su industria en el medio de una sociedad anárquica. El sujeto así conseguido entonces es una herramienta forjada a los fines de la autoconservación de la especie, y que se construye en base a una serie de represiones mediante el temor absoluto a la muerte, el siervo sufría un trabajo cosificador ya que debía trabajar sobre materiales que no le pertenecían y no podría desligar su existencia de esa actividad: su esencia se encontraba fuera de él y el trabajo se había convertido en toda su persona, y sus productos eran realizados en función del goce del amo (Hegel, 2007: 117-118). Marcuse describe en estos términos este otro sentido cosificador del trabajo en Hegel: "El trabajo encadena de tal modo al trabajador a su objeto, que su propia conciencia no existe sino bajo la forma y la figura de la cosidad. Se convierte en una cosa cuya existencia misma consiste en el hecho de ser utilizado. El ser del trabajador es un ser para otro" en Razón y Revolución, (Marcuse, 1994:.114). 
internas que van a determinar una sofocación de las dimensiones ligadas a la sensibilidad corporal a los fines de la reproducción social y el control de la naturaleza. Así planteado el análisis tiene el aspecto de un análisis genealógico ya que como dice Foucault:

la historia, genealógicamente dirigida, no tiene como finalidad reconstruir las raíces de nuestra identidad, sino por el contrario encarnizarse en disiparlas; [...] intenta hacer aparecer todas las discontinuidades que nos atraviesan (1992: 26).

El análisis adorniano busca disipar las raíces de identidad y la prerrogativa de la subjetividad de ser una instancia todopoderosa, dadora de sentido y separada del mundo, para reposicionar ese estatuto sobre bases distintas, en un sentido similar al que expresaba Foucault cuando decía de su genealogía:

la veneración de los monumentos se convierte en parodia; el respeto de las viejas continuidades en disociación sistemática; la crítica de las injusticias del pasado por la verdad que el hombre pose hoy se convierte en destrucción sistemática del sujeto de conocimiento por la injusticia propia de la voluntad de saber. (Ibídem.: 29).

Con esto Foucault desarrolló las consecuencias críticas que en su Genealogía de la Moral Nietzsche practicó como "transvaloración” de los valores de la cultura mediante la cual ciertos valores quedaban develados en su opuesto: la bondad como crueldad, el ascetismo como decadencia, la santidad como mala conciencia. De modo similar la genealogía será para Foucault un procedimiento fundamentalmente corruptor y desmitificante que deconstruye y dispersa lo solidificado. Una lectura que acentúa este aspecto genealógico de la crítica al sujeto adorniana es la de Roger Forster. Este autor afirma que en la base del mito como de la Ilustración positivista se encuentra un originario "grito de terror" ante lo desconocido, y esto ocasiona un cierre del yo como estrategia de defensa:

la tesis del dominio de la naturaleza no busca generalizar la reificación cultural mediante una antropología filosófica [como afirma Habermas]. Más bien, intenta descubrir los orígenes contingentes y extra-racionales de la restricción del pensamiento a su uso técnico, a partir de un diagnóstico de la represión colectiva que funda la racionalidad restrictiva de la Ilustración positivista. (Forster, 2001: 90, la traducción es nuestra)

Entonces lo que Adorno y Horkheimer estarían develando con esta traducción del análisis de la reificación en términos de una genealogía sería "la conexión entre las distorsión de la experiencia y los procesos sociales” (Op. Cit.). Según lo que vimos, el análisis de Foster es correcto pero, como intentaremos demostrar, es también insuficiente. 
En la medida en que no se reconozca el horizonte normativo que está acoplado a la crítica, toda lectura que sólo vea el aspecto genealógico perderá parte sustantiva del análisis: si bien Dialéctica de la Ilustración es un texto genealógico no es sólo eso, en la medida en que se propone hacer un rescate y una conservación de los ideales rectores de la ilustración. Una comparación con Foucault o con Nietzsche podría ayudar a comprender que en Adorno la genealogía está acompañada de una crítica reconstructiva o normativa, en la medida en que está siempre un "deber ser" sacado del contexto de esa historia que se está desintegrando genealógicamente: así los conceptos de sujeto, moralidad, racionalidad, etc. todavía son capaces de ofrecer contenidos emancipatorios (la posibilidad de acción moral, de crítica, de creación artística por ejemplo). De modo que la genealogía es un complemento a un concepto de racionalidad enfático que todavía sigue presente -pero cuya posibilidad de concreción histórica no está asegurada-(Honneth, 2009: 62-63). ${ }^{11} \mathrm{El}$ asunto es ver ahora mediante qué mecanismos ese viviente se autonomiza de lo natural y se configura como yo, cuál es el mecanismo de individuación que signa la consolidación de una subjetividad reificada.

\section{3.- Autoconservación}

Como dijimos, no vamos a preguntarnos por el surgimiento del orden social ni por el nacimiento de un primer sujeto por sobre lo natural, sino por el proceso de constitución de un sujeto asentado en una forma restringida de racionalidad, por el surgimiento de un sujeto que se posiciona a sí mismo en una actitud de dominación y represión de aquella naturaleza de la cual forma parte.

Para dar cuenta de esto, Adorno acude a los conceptos de "autoconservación" (Sebsterhaltung) e "identidad" (Identität); conceptos que aluden a diferentes dimensiones de un mismo proceso: en Dialéctica de la Ilustración el principio de constitución del sujeto es la autoconservación; concepto que luego en Dialéctica Negativa se problematizará con el

11 Seyla Benhabib también observó este momento genealógico de la crítica adorniana, en la medida en que esta "autoreflexión de la razón sobre las condiciones de su propia posibilidad significa descubrir la genealogía de la razón, revelar la historia subterránea de la relación entre razón y autoconservación, autonomía y dominación de la naturaleza" (Benhabib, 1986: 171). Sin embargo otorgaba a este momento un sentido negativo, ya que para ella implicaba utilizar la misma razón que se cuestiona genealógicamente como herramienta de la crítica, lo que provoca una mutación en la "lógica de la crítica" que de ese modo perdía su suelo. (Honneth, 2009: 62-63). 
nombre de identidad. Para dar cuenta de lo que Adorno entiende por autoconservación vale esta breve cita:

El sistema, en el cual la ilustración encuentra su sentido, es el conocimiento mejor predispuesto para dominar los hechos, que ayuda más eficazmente al sujeto al dominio de la naturaleza (Naturbeherrschung). Sus principios son los de la auto-conservación. La minoría de edad (Unmündigkeit) se revela como la incapacidad de conservarse a sí mismo [DA: 102] (DI 131).

En esta cita se ve claramente cómo, al afirmar la correspondencia entre ilustración, subjetividad y autoconservación, Adorno está poniendo el acento en la reciprocidad entre racionalidad y naturaleza. Lo que determina esa correspondencia es precisamente el principio de la autoconservación que en la obra de Adorno posee tres sentidos que guardan entre sí una estrecha relación procesual: 1) Es el mecanismo mediante el cual el sujeto reprime toda huella natural que puede haber en su interior, 2) es también lo natural que permanece en el sujeto en la medida en que Adorno considera que la autoconservación pertenece a lo biológico -aunque nunca se efectúa como naturaleza pura sino en un sujeto ya simbólicamente constituido-, y 3 ) es lo que amenaza al sujeto con liquidarlo, si no es mediado reflexivamente. Veamos estos tres puntos.

1) Como vimos el sujeto se constituye como instancia autónoma en la necesidad de conservarse sobre lo natural, aplazando la satisfacción inmediata en pos de una satisfacción futura y reprimiendo la tendencia al placer. Este ejercicio va a dar como resultado una forma específica de subjetividad, dominante con respecto a la naturaleza y represora con respecto a su dimensión somática y sensitiva. 2) Esta represión del placer somático ejecutada bajo el principio de la autoconservación es lo que permanece como residuo arcaico en la estructura de la subjetividad. Esa autoconservación no es un mecanismo absoluto sino el que determinada sociedad priorizó sobre otros mecanismos para constituir subjetividades. La autoconservación es natural en la medida en que Adorno lo considera como instinto de conservación o supervivencia, pero es a la vez social en la medida en que sólo en un orden simbólico determinado adquiere prioridad para construir sujetos. 3) Sucede entonces que cuando este impulso secreto no es reconocido reflexivamente y comienza a ejercer una función no mediatizada de control sobre el sujeto se produce una subjetividad menguada en sus capacidades experienciales. Sobre los puntos 1 y 2 ya 
hablamos en las líneas precedentes, veamos entonces un poco más detenidamente el punto 3.

En términos sociológicos el problema surge cuando este impulso de autoconservación permanece en las sociedades contemporáneas con un carácter anacrónico. Con su tesis del "mundo administrado" (wewaltete Welt), que analizaremos en mayor detalle en el capítulo III, Adorno pretende describir una situación histórica en la que los grandes aparatos económicos y estatales monopolizan la regulación de las esferas por la que antes transcurrían las relaciones sociales: el mercado, la sociedad civil, la opinión pública, etc. Este tipo de sociedad se caracteriza por un altísimo nivel de productividad y de obtención de márgenes de ganancias, lo que parece asegurar, no sólo su estabilidad como sistema sino también, y por primera vez en la historia humana, las condiciones materiales de reproducción social e individual, de modo que la autoconservación parecería quedar descargada en esas instancias supraindividuales.

La contraparte de este proceso es que el individuo debe adaptarse a las disposiciones de su entorno socioeconómico, de modo que el trabajo de autoconservación ahora ya no consiste en una lucha por la supervivencia -característico del período liberal y representado metafóricamente por Odiseo-, sino que más bien consiste en una adaptación a las estructuras sociales -característica de los estadios míticos en los que el individuo no estaba claramente diferenciado de la sociedad, y que se repite en el "mundo administrado"-. Así como el animismo primitivo propiciaba un intento de neutralización de las potencias naturales adaptándose a ellas, ahora el individuo de la sociedad contemporánea sólo podrá mantenerse en pie adaptándose a las disposiciones económicas y sociales de los grandes aparatos [SSI: 416] (ESI: 135). Sin embargo, esta autoconservación se continúa perpetuando como disposición ciega, y al no encontrar un campo de aplicación propicio amenaza con liquidar a la subjetividad constituida. Es, entonces, la sociedad misma la que canaliza esos impulsos de autoconservación, no ya como lucha por la supervivencia, sino como sometimiento y pérdida de la individualidad. Por eso Adorno puede decir que la autoconservación se encuentra en el núcleo del sujeto y la racionalidad, y es lo que a su vez amenaza con liquidarlo. En la siguiente cita se resumen de algún modo todos estos puntos que dejamos planteados aquí:

Que la razón sea un otro que la naturaleza, y a la vez un momento suyo, es su determinación inmanente convertida en prehistoria (Vorgeschichte). Esa razón es control de la naturaleza 
como fuerza física desviada a los fines de la autoconservación, escindida y contrapuesta a la naturaleza como a su otro. Y esto fundamenta que la razón sea, de forma efímera, idéntica y no idéntica con la naturaleza, dialéctica según su propio concepto. Pero cuanto más desenfrenadamente la razón en esa dialéctica se convierte en ley absoluta de lo natural, y se olvida de sí misma, tanto más retorna, como autoconservación desbocada, a la naturaleza. Sólo como esta reflexión la razón sería supranatural" (einzig als deren Reflexion wäre Vernunft Übernatur) [ND: 285] (DN: 287).

El análisis adorniano está intentando dar cuenta de esta relación "dialéctica" entre la racionalidad del sujeto y la autoconservación, dialéctica que consiste en una inherencia de la autoconservación natural en el sujeto pero que, al mismo tiempo, se presenta como una diferencia que amenaza con la supresión de esa racionalidad si es que no es reconocida. Esta "determinación inmanente (de la razón) convertida en prehistoria" es el punto en el que esto se hace visible, el momento en el que la autoconservación comienza a amenazar a la racionalidad, y es eso lo que la Naturgeschichte intenta sacar a luz.

Para esclarecer lo que estamos diciendo conviene realizar una comparación con un análisis distinto de la relación entre sujeto y autoconservación como es el ofrecido por Jürgen Habermas. En contraposición con Adorno, para Habermas la autoconservación en la modernidad no está determinada en función de aspectos instrumentales únicamente sino que, está atravesada por imperativos simbólicos y lingüísticos que rigen las interacciones comunicativas entre los participantes de un mundo de la vida y, de ese modo, esa autoconservación sirve para el mantenimiento de todo orden simbólico y cultural (Habermas; 1990a; 203). Sin embargo Habermas, en su Teoría de la Acción Comunicativa, se mueve con una distinción entre dos planos autonomizados de la reproducción social: la reproducción simbólica en el mundo de la vida, y la reproducción material en los sistemas de acción -como sistema económico y como sistema de poder estatal (Habermas; 1990b; 167)-. Estos sistemas de acción autoregulados permiten economizar energías a los individuos ya que los descarga de trabajo, pero adquieren un carácter ciego debido a la interconexión de sus funciones autonomizadas de la voluntad de los participantes. El diagnóstico de Habermas es que esto desemboca en un proceso de "colonización de ese mundo de la vida" por parte de los sistemas de acción autoregulados, de modo que el primero comienza a funcionar como un subsistema más (Habermas; 1990b; 255). Ambos tipos de reproducciones son racionales para Habermas, en la medida en que desarrollan 
formas de racionalidad que existen independientemente de cualquier condicionamiento natural. En tanto que Habermas no considera las formas naturales de reproducción material, tal y como por ejemplo la reproducción sexual de la especie, o bien considera a los mecanismos naturales de evolución como suspendidos en pos de mecanismos sociales, esa reproducción material se hace siempre en un plano social ya racionalmente estructurado, por lo que, según su punto de vista, la autoconservación estaría siempre atravesada por una carga de racionalidad potencialmente comunicativa, y completamente desligada de lo natural (Habermas; 1990; 506).

Con respecto al concepto de autoconservación, Adorno, a diferencia de Habermas, concibe la autoconservación como no completamente determinada por la razón pero que, al mismo tiempo, sirve de modelo para una forma precisa de racionalidad, instancia que mientras no sea reconocida reflexivamente estará latente la posibilidad de una "recaída en el mito (Rückfall auf dem Mythos)" [DA: 89] (DI: 120). Si bien la autoconservación, como algo distinto de una racionalidad enfática, pero que sin embargo se mueve en su interior, es una instancia que bien podría ser reconciliada con la racionalidad en un momento histórico de gran avance tecnológico y científico, como es el de la modernidad tardía. El problema es que, según Adorno, la racionalidad olvida esa vinculación con la naturaleza que aún persiste en ella, y entonces esos instintos de autoconservación se vuelven dominantes. De ese modo, la tesis de Adorno está en las antípodas de la idea de Habermas de que la autoconservación sea racional siempre. La tesis habermasiana supondría una visión de la razón como absolutamente desligada de lo natural, como completamente centrada en sí y sin nada heterogéneo al pensamiento discursivo (Habermas; 2008; 147).

La concepción adorniana de la autoconservación es más materialista y freudiana que la de Habermas. Incluso se podría decir que, para Adorno, la autoconservación adquiere el carácter de dominio irracional precisamente porque se entiende a la racionalidad y al sujeto como Habermas los entiende: es decir como dominios autónomos desnaturalizados, en ese sentido Habermas sería víctima de lo que vimos Adorno llamó "ideología del sujeto". Lo significativo es que sólo la razón - que para Adorno es el principio del dominio introvertido en el sujeto- es capaz de dar fin al dominio sobre la naturaleza: para esto deberíamos reconocer que nuestro comportamiento está motivado y atravesado por una carga instintiva reprimida. Tal reconocimiento sólo puede ser efectuado de modo práctico, en el curso de 
una modificación en el ordenamiento social; es decir, como una ruptura con las estructuras sociales que reproducen la represión que está en la base de la subjetividad tal y como la conocemos. En un trabajo sobre las diferencias entre Adorno y Habermas, Deborah Cook afirma que:

A través de la toma de conciencia de la naturaleza inherente al sujeto, Adorno aboga por una forma de racionalidad que domesticaría la autoconservación, pero en contraste con Habermas, él piensa que la domesticación de la autoconservación es una tarea normativa más que un hecho consumado. (2006: 47).

Es decir, lo que estaría pidiendo Adorno es la necesidad de otra forma de racionalidad que no reproduzca una autoconservación desbocada, es decir una racionalidad que no se integre simplemente en su funcionamiento a las estructuras sociales supra-individuales, sino que logre entablar una relación reflexiva con estas. Justamente una de las críticas más incisivas a este modo adorniano de plantear el problema fue la de Habermas al afirmar que esta forma de pensar la constitución del sujeto en términos de una relación cultura-naturaleza (en términos sujeto-objeto) adolece de una problematización de la constitución del sujeto en términos intersubjetivos (en términos sujeto-sujeto). Estas críticas afirmaban que, si lo que subyace debajo del sujeto adorniano es la autoconservación como principio de relación con la naturaleza, se borraría el trasfondo lingüístico e intersubjetivo sobre el cual viene ya articulado el sujeto, y es precisamente en ese trasfondo donde debía ser planteado el problema según Habermas ${ }^{12}$.

Este mismo argumento es el que subyace en la crítica al concepto adorniano de sujeto realizado por Paul Connerton. Este autor acusa a Adorno-Horkheimer de mantener un concepto de dominio asentado sobre un esquema hombre-naturaleza no referido a una dimensión intersubjetiva, y que por lo tanto ocasiona el problema de que: "la dominación social (tanto sobre otros hombres como sobre los instintos) es derivada del control sobre la naturaleza externa....". Para Connerton Adorno tendría una visión “abstracta" e "inflada" de los conceptos sujeto y naturaleza (es decir, estos conceptos no estarían mediados

12 Este es el punto que sostiene toda la critica que Habermas realiza de Adorno en su Teoría de la Acción Comunicativa, en la que se critica el presupuesto epistemológico de pensar la constitución de lo social en términos sujeto-objeto sobre un paradigma de filosofía de la conciencia, que hace imposible ver las interacciones comunicativas y sociales como fundamento de una teoría crítica (Habermas, 1990: 497). En el Discurso Filosófico de la Modernidad Habermas ya había cuestionado la autorreflexión desbocada de la crítica sobre sí misma, lo que ocasionaba una "contradicción realizativa (performativa)" que suprimía las condiciones de validez de la crítica (Habermas, 2008: 143). Para un excelente y temprano análisis de estas críticas conviene ver Hohendahl (1985: 17). 
intersubjetivamente) de modo que toda la construcción estaría basada "en una teoría de la evolución cultural reconstruida abstractamente como la historia del sujeto". Para Connerton sólo relacionando tales conceptos con una dimensión intersubjetiva "sería posible producir un modelo diferenciado de los distintos tipos de organización social, de formaciones sociales distintas" (1980: 78). Estos conceptos de sujeto y naturaleza pensados en términos productivistas (relación hombre naturaleza) y no intersubjetivos (relación sujeto-sujeto) ocasionaría en Adorno una "diabolización de la historia", en el que "la historia de la salvación es remplazada por la historia de la condenación" (Ibídem.; 75).

Esta es una crítica que tiene su fundamento en la medida en que Adorno carece de un análisis interno de las realizaciones intersubjetivas por las cuales se producen los procesos de subjetivación; ciertamente que tal cosa constituye un punto débil de su obra por lo que estas críticas darían en un punto acertado. Pero, por otro lado, estas críticas asumen siempre como dado un concepto de intersubjetividad ya lingüísticamente constituido, y es justamente la hipóstasis de un concepto de intersubjetividad así planteado lo que Adorno cuestiona con la crítica al concepto de sujeto que venimos exponiendo. Adorno no está interesado en las interacciones comunicativas entre participantes de actos de habla, sino en el origen mismo y en la estructura resultante de toda forma de conceptualización. En este sentido vale la sugerencia que Albrecht Wellmer realiza al afirmar que el análisis de la intersubjetividad en Adorno busca concebir no tanto:

...una comunicación sin coerciones, como una síntesis sin coerciones, no un reconocimiento de lo no-idéntico en el otro, sino de un reconocimiento [de] lo no idéntico en el entender la realidad y en la autocomprensión de los sujetos. Ciertamente Adorno construyó todo ello como si se tratara del establecimiento de una relación comunicativa con la realidad en conjunto (1993: 249).

Lo que está en juego no es el conjunto de relaciones que mantienen los hablantes de una lengua, sino la misma lógica de la comunicación en un sentido no cosificante, es decir, no la comunicación en sí, sino la "síntesis" de esa comunicación entendida como un proceso de construcción de la racionalidad en el marco de una relación con algo distinto -lo natural- al lenguaje comunicativo; es decir, como algo reprimido y sofocado para que esa racionalidad sea posible. Podemos decir que Adorno está un paso 
atrás de Habermas en tanto le interesa poner en cuestión lo que éste ya toma como presupuesto: las potencialidades no instrumentales del concepto y el lenguaje. Mientras que para Habermas el lenguaje es una relación siempre presupuesta y que, por esto mismo, tiene pretensiones de validez ya dadas, potencialidades de verdad, veracidad y autenticidad. El interés de Adorno, por el contrario, cae por fuera de esa comunicación siempre presupuesta, o al menos por fuera de una teoría consensual de la verdad, en la medida en que no le interesa la racionalidad comunicativa que queda a disposición en la relación hablante-hablante, sino las condiciones de posibilidad de esa racionalidad para pensar la relación entre el lenguaje y el mundo en un sentido no instrumental y no cosificador. Por supuesto que en esa relación también cabe plantear la relación hablante-hablante, pero también las relaciones no necesariamente comunicativas que se producen entre el hablante consigo mismo, con la naturaleza, y con su entorno social.

De alguna manera, Adorno está pensando en los aspectos no comunicativos del lenguaje, lo que no significa una salida mística por fuera del lenguaje sino que, alude a los modos de relacionarse de los sujetos con el lenguaje, con los aspectos somáticos y gestuales de esas relaciones, y con las lógicas coercitivas que allí se reproducen. Adorno no cuestiona al lenguaje como esfera de la racionalidad, ni tampoco al lenguaje y al concepto sólo en su aspecto instrumental, sino que está interesado en ampliar el horizonte de aquello que llamamos racionalidad, sujeto o lenguaje más allá de su aspecto comunicativo. Siempre fue bastante crítico con la idea de pensar el concepto y el lenguaje sólo desde el punto de vista de la comunicación en la medida que allí también se reproducen los caracteres identificantes e instrumentales socialmente arraigados en el concepto [ND: 51] (DN: 53), En tanto sus reflexiones no están abocadas exclusivamente a las intenciones comunicativas entre participantes de una situación de dialogo, a Adorno no le van a interesar las instancias de argumentación, sino aquello olvidado y reprimido que se esconde detrás de la comunicación empírica o a la posibilidad de esa comunicación; le preocupa la génesis y los movimientos internos sedimentados en el concepto y en la racionalidad.

Para Wellmer las reflexiones de Adorno apuntan a "la forma de síntesis en las que la comunicación puede encenderse nuevamente en cada caso, la forma de las síntesis que ponen en marcha nuevas comunicaciones y nuevos modos de comunicarse" (1993: 249). 
No existe en Adorno exista algo así como una teoría de la intersubjetividad -cosa que constituye indudablemente una deuda teórica-, pero lo que sí existe es una crítica al concepto de intersubjetividad en la medida en que ese concepto sea hipostasiado como algo ya siempre disponible. Sobre esto afirma un comentarista de su obra:

Adorno no pretende que la intersubjetividad pueda ser analizada como radicalmente separada de la dominación social y del dominio sobre la naturaleza., sino que los procesos de comunicación y mutuo reconocimiento por un lado, y la dominación por el otro, deben ser analizados como interrelacionados e involucrados. (Hammer, 2000: 79, nuestra traducción).

La idea básica de Adorno al respecto es que en una sociedad dominada por el principio de intercambio, toda relación intersubjetiva estará en buena medida reificada, sujeta a interacciones instrumentalizadas y a una percepción del otro cosificada en algún punto, pero no sólo eso, sino que esa degradación de las relaciones estará inscripta en la gramática misma de las relaciones junto con sus potenciales críticos y argumentativos ${ }^{13}$. La intersubjetividad sin bien es algo previo al sujeto, que como marco de referencia lo antecede y lo determina, también está mediada por procesos sociales de cosificación no menos ideológicos que la crítica debe desenmascarar. Por lo tanto, para Adorno la intersubjetividad no es un dato sino el objeto de la crítica. Esta idea de no hipostasiar un concepto de intersubjetividad es lo que permitiría sostener la dialéctica y abrigar un horizonte utópico. En este sentido vale la siguiente afirmación de Jarvis:

Desde un punto de vista adorniano, el pensamiento de Habermas corre el peligro de recaer en el idealismo cultural, que fuera el objetivo central de la Dialéctica de la Ilustración. Para Adorno, la acción comunicativa idealmente exitosa, realizada e intersubjetivamente transparente, no sería necesariamente utópica, ya que la condición del fin de la dominación de la naturaleza serían la disposición a reconocer que la sociedad no es pura cultura, ni subjetividad ni (solamente) intersubjetividad" (1998: 221, nuestra traducción $)^{14}$.

13Gilles Moutot tiene un interesante ensayo sobre las estrategias de Adorno para fundamentar una teoría crítica en un momento en el que considera que se hace patente que el lenguaje no es un medio transparente, y se transforma en el marco en el que las relaciones de dominación sociales se reproducen por otros medios. Moutot afirma entonces que en Adorno se produciría una "mutación semántica y funcional de la idea de crítica [...] En otros términos, lo que obliga a desplazar el cuestionamiento de las figuras a la gramática de la reificación es, precisamente, el reconocimiento de la imposibilidad para aprehender la reificación social para determinarla como objeto de una teoría" (2004: 22).

14Esta lectura de la crítica adorniana a toda hipostasiación de las interacciones comunicativas 
Por lo tanto, podemos afirmar que el ejercicio de reposicionar el concepto de un sujeto autónomo en una relación con lo natural, tal y como fue llevado a cabo por la Naturgeschichte, apunta a criticar todo intento de idealismo cultural, en el que se piensa al sujeto, a la sociedad y al lenguaje como perfectamente escindidos de toda externalidad y de toda condicionalidad en relación con la supervivencia biológica de la especie. Entonces, la praxis racional deseable no estaría dada en una comunicación exitosamente consumada, sino en la posibilidad de entablar una comunicación, no sólo en términos lingüísticos, con la naturaleza reprimida. Pero entonces surge la pregunta, ¿sobre qué fundamentos podría consumarse una praxis racional que propicie una reflexión sobre la naturaleza reprimida?. Entonces, si el análisis del concepto de autoconservación nos permitió ver que la crítica al sujeto adorniana buscó no hipostasiar ningún concepto meramente cultural o social de racionalidad, también nos hizo ver que este concepto lleva por sí mismo una exigencia. Así cuando Deborah Cook afirmaba en la anterior cita que Adorno "piensa que la domesticación de la autoconservación es una tarea normativa más que un hecho consumado”, está poniendo el acento justamente esto que aquí tratamos de argumentar.

Por eso debemos ahora ver en qué consiste esa "tarea normativa" que la crítica al sujeto prescribe. Confiamos en que esta se nos hará más patente cuando comparemos la crítica adorniana al sujeto con otro proyecto de crítica al sujeto en términos ideológicos, tal y como es el de Louis Althusser.

4.- Sujeto y normatividad

La reciprocidad entre los conceptos de sujeto e ideología que usamos para leer la crítica de Adorno fue explícitamente estudiada en el siglo XX por Louis Althusser. Fue en

\footnotetext{
también está en Whitebook quien le da un tono distinto al argumento y lo extiende contra todas la variantes filosóficas que se quedan solamente en la corroboración del "hecho de que siempre estamos in media res -en el medio de la conciencia, el lenguaje, la historia, la tradición y otros- y por eso podemos solamente acercarnos al objeto en la intentio obliqua". Para Whitebook mientras la fenomenología, el deconstructivismo, la hermenéutica y todas las filosofías contextualistas se quedan en la simple constatación de este hecho y con ello "elevan el momento de conciencia reflexionante o el lenguaje a un absoluto", Adorno avanzaría un paso más en la medida en que sostendría en todo momento la idea de que "la conciencia o el lenguaje, el cual constituye (trascendentalmente) el objeto, es él mismo constituido (empíricamente) por el objeto y no puede existir independientemente de él" (2004: 63). Es decir, para Whitebook la conciencia lingüística es siempre función de la vida, está originada en la naturaleza que se reprime y no puede ser hipostasiada sin caer en un trascendentalismo dogmático.
} 
su obra en la que los conceptos de sujeto e ideología fueron vinculados de una forma novedosa. Althusser en su "Ideología y Aparatos Ideológicos del Estado" (1969) parte de la misma pregunta que orienta a toda la teoría crítica: “¿cómo se asegura la reproducción de las relaciones de producción?” (2003: 129). El centro de esta reproducción social cae del lado de los "Aparatos Ideológicos de Estado" (AIE) que son múltiples y autónomos y operan mediante la ideología - la escuela, la familia, los medios de comunicación, los partidos políticos, la Iglesia, la cultura, etc.-. Pero, ¿cómo se produce ese operar ideológico?, ¿cómo se asegura la reproducción social a partir de los AIE. Althusser elabora para esto una teoría "de la ideología en general" (Ibídem.: 137), es decir explica el funcionamiento de las ideologías particulares históricamente determinadas mediante un mecanismo ideológico que las atraviesa. Para Althusser este mecanismo o "ideología en general" "no tiene historia propia", es "eterna", lo que "no quiere decir trascendente a toda historia (temporal), sino omnipresente, transhistórico y, por lo tanto, inmutable en su forma en todo el transcurso de la historia" (Ibídem.: 138), por lo tanto se trata de un mecanismo que recorre los diferentes aparatos ideológicos y define el modo general en el que estos funcionan.

Althusser intenta dejar de pensar este concepto de ideología como ilusio, es decir como un reino imaginario o abstracto cuya realidad se encuentra por fuera de sí misma. Para esto va a decir que no son las condiciones de existencia lo que los hombres se representan en la ideología, sino que es su relación con esas condiciones de existencia lo que constituye el fundamento de la ideología, ya que esta "representa' la relación imaginaria de los individuos con sus condiciones materiales de existencia” (Ibídem.: 139). Esa relación imaginaria que sostiene lo propiamente ideológico es necesariamente imaginaria en la medida en que construye un conjunto de evidencias y significados sociales que los hombres asumen como obvios y constituye su mundo social. Esas evidencias ideológicas -esa representación imaginaria que los hombres poseen con sus condiciones materiales de existencia-, no son de carácter ideal o no emanan de una conciencia constituyente, sino que poseen un carácter profundamente material y práctico. Un sujeto tendrá una ideología para Althusser sólo si esas ideas "son actos materiales, insertos en prácticas materiales, reguladas por rituales materiales definidos, a su vez, por el aparato ideológico material del que proceden esas ideas" (Ibídem.:143). 
Sin embargo, Althusser va más allá de esta constatación del carácter material de la ideología al indagar en la relación que esa ideología guarda con la constitución de la subjetividad. Y es en este momento, al indagar en esa relación entre el sujeto y la ideología, que consideramos que Althusser obtiene su carácter más profundamente crítico, ya que sólo con este paso podrá dar cuenta de las relaciones coercitivas y de poder que se esconden detrás del sujeto. Para Althusser la ideología "sólo existe por y para los sujetos", es decir la categoría de sujeto es constitutiva de toda la ideología "en tanto toda ideología tiene por función la 'constitución' de los individuos concretos en sujetos" (Ibídem.: 145). Para Althusser hay entonces un juego de "doble constitución” entre la ideología y la categoría de sujeto: por un lado la ideología constituye a los sujetos, pero sólo hay ideología en el marco de esos sujetos ideológicamente constituidos, es decir en el marco de las prácticas materiales que definen a esos sujetos. El sujeto y la evidencia para este de su autonomía constituyen el efecto ideológico por antonomasia, la evidencia ideológica más pregnante y más obvia: estamos seguros de que somos dueños de nuestras acciones, nos parece un dato obvio nuestra libertad para elegir entre el bien y el mal, de que nuestro gusto estético es expresión de nuestros sentimientos y representaciones, etc. En concreto, la ideología impone las evidencias que no podemos dejar de reconocer, y las impone a partir de un mecanismo específico: a partir de un juego de interpelación/reconocimiento. La ideología funciona de forma práctica, pero funciona en el marco de una situación de interpelación dirigida al sujeto que a su vez se reconoce en el llamado de esa interpelación (por ejemplo, responder ante la enunciación de nuestro nombre constituiría una forma básica y paradigmática de interpelación/reconocimiento ideológico). Para Althusser somos "siempre ya sujetos" que practicamos "sin interrupción los rituales del reconocimiento ideológico que nos garantizan que somos realmente sujetos concretos, individuales, inconfundibles y (naturalmente) irremplazables" (Ibídem.; 146): me reconozco como un padre de familia, cristiano, sostén del hogar, trabajador, conservador o como un intelectual, liberal, comprometido, tolerante, etc.

La ideología interpela entonces como sujetos concretos a los individuos concretos, opera mediante su "reclutamiento" para hacerlos formar parte de la milicia de sujetos que "andan solos". Por lo tanto, la categorías de sujeto, ideología e interpelación/reconocimiento se realizan para Althusser en un sólo momento y se repiten en 
cada acción práctica. Lo interesante en el análisis de Althusser es que una de las evidencias ideológicas, que acompaña a la evidencia sujeto, es la evidencia de negación de la propia ideología: la ideología al generar un mundo de evidencias en el que nos actuamos también genera la creencia de que, en tanto que sujetos dueño de nuestras acciones, estamos afuera de la ideología (Ibídem.: 148). Esta ilusión del carácter no ideológico de nuestra posición como sujetos no es sino otro modo que toma la evidencia de un sujeto autónomo: la ilusión de que el sujeto es dueño de sus actos y que puede entrar y salir de la ideología siempre a voluntad. Para Althusser los individuos son siempre-ya sujetos interpelados ideológicamente, no hay individuos sino es en el marco de la ideología, no hay individuos que no sean a su vez sujetos; incluso antes de nacer un individuo está interpelado (recibe un nombre, una identidad sexual y un conjunto de expectativas) y se reconoce a través de sus acciones en esas interpelaciones. Por lo tanto, la imbricación entre ideología y subjetividad, que se produce a partir de los mecanismos de interpelación/reconocimiento, funcionan como el modo general mediante el cual nosotros construimos las evidencias y asumimos nuestra relación con nuestras condiciones materiales de existencia.

Al igual que Althusser, para Adorno el concepto de sujeto es un concepto ideológico en la medida en que se construye como una evidencia o un cierre de sentido mediante mecanismos que anteceden al sujeto pero que sólo son posibles en él: en Althusser la interpelación de los AIE y su reconocimiento, en Adorno la autoconservación/identificación. En ambos autores se intenta poner en cuestión el carácter constituyente de la conciencia, y mostrar que es el resultado de procesos e instancias determinadas, pero que sin embargo se reproduce como evidencia en un conjunto de prácticas que ella hace posible. Para ambos autores la ideología y el sujeto son dos conceptos que deben ser analizados conjuntamente en tanto el sujeto, como forma ideológica general y primera, es la evidencia que debe ser desbancada, y en tanto sólo hay ideología por y para un sujeto, es decir en tanto los mecanismos de interpelación/reconocimiento o de identificación represiva/autoconservación sólo existen en el marco de un sujeto que a su vez es producto suyo.

Si bien existen cruciales diferencias entre el análisis de Althusser, llevado a cabo en términos de estructuras de significación que se entrecruzan en un tiempo diacrónico, y el análisis de Adorno, llevado a cabo en términos de un proceso de racionalización social 
desarrollado en una historia civilizatoria, consideramos que la diferencia más significativa, y la que nos da la pauta de la singularidad dialéctica de la crítica al sujeto efectuada por Adorno, es aquella que atañe al modo de concebir la relación entre verdad e ideología en ambos autores. Para Althusser existe un afuera de la ideología, sólo que ese afuera de la ideología ya no se da con la forma del sujeto, sino en el espacio de una ciencia sin sujeto como práctica teórica ${ }^{15}$. Mientras que para Adorno ese afuera de la ideología se da sólo con y a partir del sujeto, en la medida en que es en el sujeto donde se nos ofrece la prefiguración de ciertos contenidos de verdad y las herramientas para tematizarlos.

El sujeto para Adorno es, según vimos, el producto de un proceso de represión de una objetividad representada mediante el concepto de naturaleza, y que entabló una relación diezmada con toda exterioridad. Lo interesante es que en la medida en que Adorno conciba al sujeto en el marco de una relación sensitiva reprimida y sublimada, ese sujeto se mantendrá como una instancia que despertará ciertas exigencias que la crítica debe tener presente y dar voz. Para Adorno, a diferencia de Althusser, el sujeto no es una unidad ficticia producida a partir del acoplamiento de estructuras o la intersección de interpelaciones ideológicas que el sujeto debe simplemente reconocer. La crítica materialistaque Adorno lleva a cabo intenta develar en el interior del sujeto las cicatrices de un proceso de represión como daños físicos y psicológicos, como menoscabamiento de la capacidad de relacionarse con el entorno material y social, como cosificación de los sentidos y las experiencias:

La huella más pequeña de sufrimiento (die kleinste Spur sinnlose Leidens) sin sentido padecido en el mundo inhabilita toda la mentira de la filosofía de la identidad, que quería disuadir de la existencia del dolor a la experiencia [...] El momento corporal (Das leibhaflte Momen) le marca al conocimiento que el sufrimiento no puede ser, que debe cambiar. [...]. Por eso convergen lo específicamente materialista con lo crítico, con la praxis socialmente transformadora. [ND: 203] (DN: 203-204) ${ }^{16}$.

15En Althusser la diferencia entre la ideología y la ciencia como práctica teórica no es una diferencia sustantiva, sino que se encuentra al nivel del modo cómo se ejercitan ambas, es decir al nivel de la naturaleza de su problemática: mientras que la ideología asume evidencias ya constituidas, la ciencia posibilita la problematización continua de sus presupuestos, puede profundizar los conocimientos que produce en un proceso de transformación interna continua y que, en algunos casos, provoca rupturas totales al interior de una problemática, como en EL Capital de Marx con respecto al hegelianismo, o como Einstein con respecto a la física newtoniana. (1967: 150-160). Para ver un análisis de la relación entre ideología y epistemología en Althusser poniéndolo en discusión con la tradición del marxismo hegeliano ver Callinicos (1978).

16 En este sentido es que Jarvis define al materialismo adorniano no como "un conjunto de 
El concepto de sufrimiento físico tiene una importancia fundamental en la crítica materialista de Adorno en la medida en que es leído como signo de una violencia que debe ser desactivada. El sufrimiento es huella de esa represión que debe ser teorizada como exigencia de anulación de la violencia, y debe ser articulada dentro de la teoría como fundamento para pensar una praxis racional. El sujeto entonces es el índice que tiene la teoría para conceptualizar la experiencia, y a la vez es la herramienta de esa conceptualización ya que el pensamiento, el concepto y la crítica sólo son posibles a partir de él. Por lo que el sujeto no debe ser desechado sino consumado, es decir liberado de su celda ideológica y del conjunto de evidencias asumidas mediante un rescate de la exigencia de no sufrimiento. De modo que el sujeto para Adorno posee una carga normativa que el concepto de sujeto ideológico de Althusser no posee. Es decir, para Adorno el afuera de la ideología está dado dentro del sujeto y no afuera; la posibilidad de actualizar un contenido de verdad está presente en la forma de una subjetividad que expande sus límites y concibe un acercamiento a esa objetividad -la naturaleza interna y externa- en la forma de una experiencia en la que los mecanismos perceptivos son ampliados, y en el que las tensiones por las represiones sufridas son atemperadas. No hay un afuera del sujeto para Adorno, pero sí hay un afuera de la ideología como posibilidad de consumar una apertura del cierre subjetivo y un encuentro con lo otro: no es que la subjetividad sea ideológica, sino que es el cierre de esa subjetividad lo ideológico.

Honneth resalta este aspecto normativo del sujeto en un contexto muy interesante:

El individuo humano adquiere libertad en la medida en que, sin ser forzado, entrega su vida de pulsiones y de imaginación a la diversidad sensible de las impresiones recibidas de la naturaleza [...]. Este concepto estético de la identidad del yo, proporciona a Adorno no sólo la pauta para una crítica de la subjetividad moderna, sino, al mismo tiempo, el punto orientador para una interpretación

compromisos metodológicos ni metafísicos fijados", sino como lo que "podría ser llamado más precisamente como un impulso: el deseo utópico de una felicidad sin engaños, incluido el placer corporal, el deseo de un final para el sufrimiento" (2004: 80). Es decir, no sería un materialismo como visión del mundo como en el empirismo, ni un materialismo metodológico como el que enarbolaba Lukács, sino un materialismo normativo y ético puesto que en Adorno "el materialismo consiste más bien en una reinterpretación de la experiencia social sedimentada en el modo filosófico que ha devenido dominante en nuestro entendimiento de la cognición" (Ibídem.: 97). Esa experiencia social sedimentada es también la experiencia de los sufrimientos padecidos y de los cuales la filosofía debe dar cuenta. 
exploradora del proceso de civilización. (2009b: 147).

Es decir, en la medida en que Adorno se maneje con un concepto de sujeto configurado en base a mecanismos represivos, y que entienda a toda subjetividad como producto de un cierre ideológico que provoca daños en la experiencia de los individuos; esto es, en la medida en que, como dice Honneth, Adorno tenga un concepto "estético de la identidad del yo", la crítica del sujeto se dará con un carácter normativo, como exigencia de que los sufrimientos provocados civilizatoriamente por la racionalización sean revocados $y$, a la vez, como exigencia de que esa subjetividad sea liberada de su encierro en una relación pacífica y no subjetivista con lo otro que el sujeto. El materialismo adorniano es lo que nos ofrece entonces el momento normativo de la crítica al sujeto. De ese modo el carácter dialéctico que describimos anteriormente ahora recién se nos abre en un sentido más profundo: la crítica a la ideología del sujeto debe desbancar al sujeto autónomo y rescatar de ese modo el potencial crítico y práctico que ese concepto normativo posee.

Esto es lo que devela también el análisis comparativo que Christoph Menke realiza de la crítica de la moral en Nietzsche y en Adorno. Según esta lectura, para Adorno:

contrariamente a la concepción homogénea de la moralidad en la genealogía de Nietzsche [...], la moralidad no consiste solamente en algo que causa daño a la vida y a la libertad de los individuos. Antes bien, esta forma de moralidad no puede ser comprendida si no es vista como la expresión distorsionada de un impulso básico de la moralidad, es decir, el impulso a la solidaridad para con los individuos y con el cumplimiento de sus vidas. (2004: 320)

Para Menke esa crítica basada en la ética individual que Nietzsche y Adorno comparten, se diferencia en que Adorno la realiza sobre una base normativa que se asienta en el impulso básico de solidaridad por el sufrimiento de los individuos. Independientemente de qué estatus tenga este impulso, esta lectura da cuenta de que la genealogía tendrá entonces la misión de indagar hasta qué punto los ideales originales conservaron o no su significación originaria: por 
ejemplo preguntarse hasta qué punto el concepto de emancipación ligado al sujeto se conserva, hasta qué punto la promesa de libertad puede dar cuenta de todas las víctimas y de todos los sufrimientos de la historia.

El sujeto que la civilización construyó, y que la filosofía hizo suyo, fue moldeado en la lucha por la autoconservación, en el que los componentes afectivos fueron relegados en función de la reproducción social. El sujeto se constituyó en una herramienta de trabajo y dominio, y todo aquella dimensión que no se amoldara a tales disposiciones fueron relegadas o reprimidas. Este sujeto dado como instancia evolutiva representó una forma de relacionarse con el mundo basada fundamentalmente en una relación de manipulación técnica y homogeneización cognitiva, pero para tal cosa necesitó entablar esa misma relación con su naturaleza interna, con su dimensión como ser ligado a lo biológico. Esto le acarreó cuotas altísimas de sufrimiento al que sin embargo no era capaz de poner en palabras puesto que al sujeto racional:

...le es ajeno el sufrimiento, puede definirlo subsumiéndolo, puede poner medios para calmarlo, pero apenas puede expresarlo mediante su experiencia: incluso lo considera irracional. El sufrimiento, llevado al concepto, permanece mudo y sin consecuencias: esto se dejó observar en la Alemania de Hitler. [ÄT: 35] (TE: 52)

Entonces para Adorno el sujeto es más que una mera ideología; y esto es lo que lo diferencia con respecto a otras crítica a la subjetividad que durante el siglo XX tomaron el centro de la escena filosófica, tal y como lo vimos en la Introducción. Estas filosofías no subjetivistas demolieron el concepto de sujeto de diferentes modos: el sujeto como una consecuencia de prácticas de interpelación de la ideologíacomo vimos en Althusser, el sujeto como resultado de prácticas de saber/podercomo en Foucault, el sujeto como resultado de una interrelación de significados múltiples dados comunitariamente como se puede leer a partir de Wittgenstein, etc.. Ahora vemos que la diferencia entre estas posiciones y la posición adorniana es que, en Adorno, el sujeto no solamente es resultado de una 
heterogeneidad interna a lo social, no sólo se organiza en la multiplicidad de significados a las cuales accede como algo dado y que lo antecede constitutivamente; sino que la heterogeneidad que constituye al sujeto es una heterogeneidad más radical digamos, es la misma naturaleza que en su carácter de diferencia también es capaz de destruir a ese sujeto. Por lo tanto, en el marco de la filosofía adorniana los juegos sociales de significaciones no serían el dato primero, sino que ese conjunto de prácticas de significación que está disponible para los individuos se constituye en una práctica social previa de relación con la naturaleza. Sólo llevando esto a reflexión se hace perceptible el universo simbólico social o se nos abre el mundo de la vida sobre el cual el sujeto se mueve y por el que es constituido. Se trata de pensar una forma precisa e histórica de sujeto que una forma precisa e histórica de sociedad construye reprimiendo a la naturaleza. Es en esa brecha entre la naturaleza y la constitución del mundo social donde pone el acento la crítica adorniana.

La Naturgeschichte consistía en hacer visible la imbricación del sujeto con la naturaleza para desbancar esa pretendida autonomía subjetivista, y de ese modo sacar a luz que el sujeto es el producto de ciertos mecanismos de represión y control de esa objetividad natural que lo constituye. Adorno consideraba ideológica esta subjetividad que se posicionaba como instancia cerrada sobre sí misma y que borraba las huellas de sus condiciones de posibilidad. Esta subjetividad al reprimir su naturaleza interna sofocaba también todo el plano afectivo y emocional en pos de adaptar la instancia así conseguida a los requerimientos productivos de la sociedad, de modo tal que en el sujeto sólo fueran revalorizadas las disposiciones intelectuales relacionadas con el control de las cosas. Ese contexto de frialdad sobre el que fueron forjados los verdugos, y al que aludimos en nuestra Introducción, comienza a ser explicado en este paso.

De este modo, el mecanismo que posibilitó la emergencia de una subjetividad por sobre el reino natural fue la autoconservación, que consistía básicamente en el aplazamiento de la satisfacción de los deseos y en la racionalización del intercambio con la naturaleza. Vimos que este mecanismo es el elemento natural que pervive en el sujeto en la figura de la racionalidad 
instrumental o del pensamiento de la identidad y que, al cosificar toda experiencia humana, pone en peligro a la misma racionalidad. Mostramos también cómo a diferencia de Habermas, para quien la autoconservación ya es en sí misma racional, para Adorno representa una exigencia de autorreflexión del sujeto sobre aquella naturaleza reprimida, una tarea que todavía debe ser cumplida. Esto nos llevó a afirmar que en este análisis el sujeto es más que "la ideología del sujeto", es más que una ilusio ideológica, puesto que el sujeto es también un proyecto histórico que guarda ciertas peticiones morales que deben ser actualizadas. Esta normatividad inherente quedó mejor expuesta cuando comparamos el análisis de la ideología del sujeto de Adorno con el análisis althusseriano de un sujeto construido ideológicamente mediante la interpelación y el reconocimiento. Así el sujeto adorniano se nos develó como una instancia no enteramente ideológica, ya que su misma existencia guardaba la posibilidad de una praxis racional atenta al sufrimiento de los individuos bajo las actuales condiciones existentes.

En esta primera etapa de la crítica nos adentramos en el origen de ese contexto de frialdad propio del sujeto que Adorno denuncia como condición de la ocurrencia de Auschwitz. Pero este modelo de sujeto construido sobre represiones en el contexto de una historia natural de supervivencia de la especie será el que asuma la filosofía durante la modernidad. Ese sujeto de la filosofía que como una instancia autónoma se postulaba como dadora de sentido, como garantía, como principio desde el cual se deducía la realidad, como condición de efectividad de una praxis correcta, será para Adorno fundamentalmente una consecuencia del sujeto construido como unidad de autoconservación en una relación con la naturaleza. Sin embargo esto, el sujeto que la filosofía asuma desde Descartes tendrá sus particularidades, por lo que ahora tendremos que enfocarnos en el sujeto tal y como lo pensó la gnoseología. El conocimiento fue la esfera privilegiada del pensar filosófico durante toda la modernidad, y fue la racionalidad del conocimiento científico la que sirvió como arquetipo del concepto de razón. Será por esto que enfocar la crítica en la teoría del conocimiento significará someter a juicio a toda la tradición moderna. Pero también confiamos en que será en ese momento donde podrá quedar un tanto más clara la idea de un sujeto 
liberado de su encierro a partir de una ampliación de su capacidad experiencial. Con la crítica al sujeto de la teoría del conocimiento entramos en el centro de la tradición filosófica y, al mismo tiempo, confiamos en que así se nos hará presente ese rescate de un concepto de sujeto no ideológico que Adorno pretende. 


\section{METACRITICA DE LA TEORIA DEL CONOCIMIENTO}

En este capítulo analizaremos otra dimensión de la crítica al sujeto emprendida por Adorno que va a guardar una relación de complementariedad con la analizada en el capítulo anterior. Si, como vimos allí, la crítica al sujeto era llevada a cabo en los términos de una historia natural en el marco de la relación hombre-naturaleza, ahora la crítica será llevada como una metacrítica a la teoría del conocimiento en el marco de una relación sujeto-objeto. Intentaremos desarrollar este último modelo de crítica y demostrar que ambas están relacionadas en tanto se dan como críticas a una subjetividad absolutizada, como reposición de una objetividad reprimida y como críticas normativas que exigen un sujeto ampliado en términos experienciales. El eje de este capítulo será mostrar cómo Adorno analiza el problema del conocimiento en el marco de la relación sujeto-objeto para pensarlo bajo la idea de una experiencia que no se limite a lo cognitivo y que sea capaz de liberar al sujeto de su inmanencia. En este capítulo, en consecuencia, va a quedar un tanto más clara la dinámica interna de ese sujeto constituido sobre represiones y la relación de violencia identificadora que guarda con toda exterioridad. Una vez analizado el sujeto de la epistemología vamos a poder enfocarnos en el sujeto cosificado que el imperativo categórico pos-Auschwitz exige problematizar.

Pero antes de seguir retomemos las conclusiones del capítulo anterior. En la crítica al sujeto como historia natural pudimos apreciar la centralidad del concepto de sujeto en el marco del pensamiento adorniano, debido a que consideraba que la absolutización de la esfera subjetiva fue el gran problema de toda la historia del pensamiento; pero también vimos que, si no se da cuenta de cierta capacidad agencial de ese mismo sujeto, sería imposible cualquier forma de pensamiento reflexivo. En ese carácter ambivalente, dialéctico, de la crítica al 
sujeto que seguirá siendo el eje de nuestras lecturas: debemos mostrar la singularidad de este análisis que pretende, por un lado, una demolición del sujeto y por otro un rescate de sus potencialidades.

Volviendo a la cita que nos sirvió para plantear nuestro problema podemos decir que en la problemática adorniana "la ideología del sujeto" consiste en "el encantamiento del sujeto en su propio fundamento de determinación; en su posición como ser verdadero", por lo que el trabajo de la crítica debería "retrotraer al sujeto mismo a su objetividad", pero sin "proscribir sus impulsos al conocimiento" [SW: 749] (CN: 150). En este marco vimos cómo la crítica mostró la objetividad constitutiva de la subjetividad, reposicionando el problema en una "historia natural", que consiguió descentrar al sujeto en una relación civilizatoria con una naturaleza heterogénea, de modo tal de dejar visibles los mecanismos de autoconservación represivos constitutivos de subjetividad.

Pero ahora se trata de replantear ese proceso de constitución de la subjetividad en términos, no ya de una relación con lo natural, sino de una relación sujeto-objeto, tal y como fue elaborado por la teoría del conocimiento idealista. Es decir, pasar del plano de una historia evolutiva al de una historia de la filosofía. Esto implica retomar la problemática idealista pero no para invertirla, sino para desbancarla desde adentro, para hacer ver su carácter ideológico y represivo. Se trata ahora de mostrar la "objetividad" que se esconde detrás del sujeto de la gnoseología -del mismo modo que en la "historia natural" se trataba de mostrar la naturaleza escondida tras el sujeto escindido de su origen natural-, y en esa subjetividad redescubierta problematizar las instancias que otorgarán al sujeto los puntos desde los cuales emprender su rescate. Comencemos analizando entonces los términos en los que se produce esta segunda modulación de la crítica.

\section{1.- Metacrítica de la teoría del conocimiento}

Al programa de crítica de la relación sujeto-objeto de la gnoseología moderna Adorno le dará diferentes nombres -"crítica de la conciencia constitutiva", 
“lógica de la desintegración", "dialéctica negativa”, o "metacrítica de la teoría del conocimiento"- en este texto escogimos plantear esa crítica bajo la rúbrica de "metacrítica de la teoría del conocimiento" ya que es esta denominación la que consideramos expresa más cabalmente el hecho de que lo aquí se produce es un replanteo profundo de la relación sujeto-objeto del marco gnoseológico idealista. Esta idea de una "metacrítica" aparece en el ensayo crítico sobre Husserl que Adorno publicara hacia 1956; tal metacrítica no pretendía ser otra cosa sino una crítica materialista al marco representacionalista y subjetivista de la gnoseología moderna. Como Martin Jay lo indica: "metacrítica significa ir más allá del reino de la filosofía per se para adentrarse en sus fundamentos históricos y sociales, pero sin reducirla a éstos, al estilo de una vulgar sociología del conocimiento" (Jay, 1988: 51).

La centralidad de este programa queda claramente marcada en el prólogo a Dialéctica Negativa: "Desde que el autor cobró confianza en los propios impulsos espirituales, sintió como su propia tarea quebrar, con la fuerza del sujeto, el engaño de la subjetividad constitutiva" [ND: 10] (DN: 8). "Con la fuerza de sujeto" indica aquí que esta tarea debía realizarse con los mismos medios de esa subjetividad para "remplazar el principio de unidad y la omnipotencia del concepto soberano por la idea de lo que estaría fuera del hechizo (Bann) de tal unidad" [ND: 10] (DN: 8). Esta última frase puede ser interpretada como una apuesta en el terreno de la crítica de la ideología: la apertura del cierre o "hechizo" ideológico deberá efectuarse con los medios y las herramientas con los que se produce ese cierre; así el sujeto será pensado como el producto de una sutura ideológica que se realiza en un campo de sentidos, de modo que categorías que se entendían como propias del sujeto -tales como autonomía, unidad, garantía o principioquedarán develadas como ilusio. En otras palabras, esta constitución de la subjetividad que analizamos en el anterior capítulo en términos de una historia evolutiva, ahora la veremos en los términos de la relación cognoscitiva.

Ahora bien, en este momento el programa critico materialista de Adorno puede ser definido de la siguiente manera: "crítica de la sociedad es crítica del 
conocimiento y viceversa"(Kritik an der Gesellschaft ist Erkenntniskritik und umgekehrt) [SW: 748] (CN: 149), afirmación que nos indica que la crítica a la relación sujeto-objeto pretende ir más allá de los límites de la epistemología. Fundamentalmente, esto expresa que el sujeto idealista sólo podrá ser desbancado mediante una crítica materialista en el sentido de una autocrítica social del conocimiento; empresa que en Historia y Conciencia de Clase (1923) de Gyorgy Lukács encuentra su momento ejemplar. En ese trabajo Lukács ejercitaba una lectura en clave materialista de la filosofía de la historia hegeliana en la que era el proletariado, y ya no el Geist, el sujeto-objeto de la historia; de modo que la sociedad sólo bajo su tutela como clase universal podría llegar a la realización histórica de la libertad. Pero para Lukács el impedimento de esta emancipación era el proceso de reificación social que se había expandido en la sociedad capitalista a partir de la relación asalariada de trabajo. Es también ese proceso de reificación el que se introducía en la relación cognoscitiva entre el sujeto y el objeto tal y como lo había pensado la filosofía. Es esto lo que Lukács intentó demostrar en la sección "Las antinomias del pensamiento burgués" de su influyente artículo "Reificación y conciencia del proletariado", donde Lukács pretendía llevar la crítica filosófica más allá de la filosofía, ejercitando una crítica a las formas sociales de racionalidad, tal y como quedó plasmado en su singular lectura de Kant.

Según Lukács, Kant restringe el conocimiento de la cosa en sí y lo limita al trabajo con los fenómenos, con esto le otorga al sujeto un carácter creativo, pero a costa de que a ese sujeto espontáneo ahora se le anteponga un algo dado que lo limita en la pretendida actividad que la filosofía le asignaba. Es justamente eso dado, que como cosa en sí incognoscible permanece como irracional, lo que según Lukács contradice las ambiciones del racionalismo que se presenta "con la pretensión de ser el método universal para el conocimiento de todo el ser" (2009: 225) y amenaza con el colapso de su empresa. Así el racionalismo no puede dar cuenta de esa materia irracional que se le antepone al pensamiento racional y deviene en "un mero registro [...] de hechos cuya conexión, empero no es ya racional, o sea no es ya sistematizable" (Ibídem.: 231). En este marco el 
racionalismo no sería más que un sistema de esquematización en el cual piezas atomizadas de la realidad son puestas en orden. Lukács afirma que ese modelo de sujeto sólo es posible en la sociedad moderna, compuesta de individuos aislados y estructurada sobre el interés egoísta. Con este análisis se establece una relación entre la filosofía y los modos establecidos de racionalidad de la sociedad burguesa, y con ello se entiende a la filosofía clásica alemana como el máximo nivel de autoconciencia filosófico de la sociedad burguesa.

El problema, entonces, queda definido en base a dos ideas: (1) la racionalidad epistemológica define que sólo somos capaces de conocer lo que hemos creado; esto va paralelo a que la sociedad burguesa consigue un creciente control sobre todo los detalles de su existencia social en función de sus necesidades, pero (2) esa misma racionalidad epistemológica puede dar cuenta de la forma del pensamiento de modo trascendental, pero no de aquello dado de la materia que como noúmeno permanece en una esfera de irracionalidad; esto mina las pretensiones de sujeto kantiano de ser el punto de vista de la razón y, a la vez, manifiesta una limitación de la capacidad de la burguesía para abrigar un concepto universalista de libertad debido a su estrecho interés de clase. Es decir, el problema estaría en otorgarle una espontaneidad al sujeto y a la vez limitarlo con la asunción de una materia irracional. Pero esto no es sólo una inconsistencia teórica para Lukács, sino que expresa la profunda autoconciencia de la filosofía alemana con respecto a la sociedad burguesa. Esta situación es la que se observa en términos sociales con las infinitas potencias transformadores del sujeto burgués limitados, sin embargo, por su inserción en una sociedad de clases. Las tendencias del desarrollo social se manifiestan en la filosofía misma en la forma de antinomias. Esto responde a un estado en el que:

la clase burguesa domina crecientemente las singularidades y los detalles de su existencia social y los somete a las formas de sus necesidades, pero al mismo tiempo y también crecientemente, pierde la posibilidad de dominar intelectualmente la sociedad como totalidad y por lo tanto su calificación como clase dirigente. (2009: 234) 
Si bien Adorno no considera que la crisis de la racionalidad moderna esté conectada con un problema de clase o de algún tipo de sujeto colectivo ${ }^{17}$, comparte los términos en los que el análisis fue realizado con la equivalencia entre crítica del conocimiento y crítica social que el texto de Lukács planteaba, con la idea de que las formas filosóficas están constituidas con el mismo molde que las formas de la racionalidad que estructura la vida social. Es por eso que las formas de la racionalidad no son neutras ni leyes a-históricas del pensamiento, por lo tanto la crítica a la filosofía y a su modelo de racionalidad debe plantear una crítica social en un sentido más amplio. Sería entonces esta influencia lukacsiana, central para todos los intelectuales de izquierdas formados durante Weimar (Wiggershaus: 100-109), la que estaría escondida detrás de la fórmula metodológica materialista "crítica de la sociedad es crítica del conocimiento y viceversa".

El proyecto "metacrítico" entonces intentará descifrar los elementos materiales que se conservan dentro de las estructuras ideales del modelo sujeto-objeto, pero respetando su autonomía, de modo que sea en la gramática misma de esa relación donde puedan reconocerse las cicatrices de lo social. En ese sentido metacrítica también significará crítica inmanente. Esto es lo que hace que la acusación de Habermas de que la filosofía adorniana se da como una "filosofía de la conciencia" tenga cierto asidero: Adorno intenta desbancar al sujeto mediante el propio sujeto, por lo que se trataría en todo caso de una filosofía de la

17Martin Jay ofrece un interesante análisis de las distancias que separan a Adorno de Lukács en su capítulo denominado "Adorno and the Luakácsian Concept of Totality" en Jay (1984b). A partir de una lectura de la oposición de Adorno al concepto expresivo de totalidad lukaciano es que analiza Jay el legado de la filosofía adorniana que: "ha demolido irrevocablemente la inicial fundamentación del marxismo occidental en el concepto de totalidad. O si se prefiere una explicación más históricamente materialista, la dialéctica negativa teoréticamente comprometida con cambios fundamentales en la realidad social, hace demasiada obvia como para ignorarla la debilidad del paradigma lukaciano. Un marxista occidental ya no podrá defender una expresiva visión del todo en el cual un meta-sujeto sea tanto sujeto como objeto de la historia. Ya no podrá la historia ser vista como un todo coherente con una conclusión positiva como su telos. Ya no podrá la totalidad ignorar la no-identidad de lo histórico y lo natural subordinado a la dominación social. Y nunca más podrá la totalización epistemológica de la tradición hegeliana ser invocada con confianza contra las antinomias del pensamiento burgués" (Jay, 1984b: 274). Este balance del legado de Adorno al interior del marxismo hegeliano puede funcionar también como balance de su obra con respecto a la tradición metafísica. 
conciencia anti-subjetivista, o de una filosofía de la conciencia que intenta mostrar de modo inmanente sus propias incongruencias. La particularidad de esta crítica inmanente tiene su fundamento en los rasgos más eminentemente ilustrados de Adorno, ya que sólo mediante esta autodisolución interna del sujeto pueden quedar, a su juicio, liberados los potenciales que ese mismo sujeto guardaba.

Como vimos en el capítulo anterior, Adorno no intenta deshacerse del sujeto como de un resto molesto y anacrónico, sino salvar lo que ese sujeto atesora de valioso: la posibilidad de la crítica, la realización de una experiencia ampliada, la singularidad y la autonomía como resistencia en el mundo homogeneizado, o como veremos, el momento normativo de la subjetividad. La esperanza radica ahora en que sólo luego de la destrucción de la ideología del sujeto esos elementos normativos puedan ser rescatados y relaborados. Así al final de Dialéctica Negativa Adorno afirma:

Los más mínimas tendencias intramundanas tendrían relevancia para lo absoluto, pues la mirada micológica rompe la cubierta de lo que, según la pauta del concepto genérico subsumidor, está aislado desamparadamente y hace estallar su identidad, el engaño del que sería apenas un ejemplar. Tal pensamiento es solidario con la metafísica en el instante de su caída. [ND: 400] (DN: 405)

Lo mismo que con respecto a la metafísica podemos decir con respecto al sujeto: la crítica del sujeto se solidariza con él "en el instante de su caída", ya que una vez disuelta la cáscara ideológica del sujeto pueden quedar liberados sus elementos racionales y utópicos.

Entonces volviendo al centro de la crítica al sujeto, podemos decir que según Adorno el punto débil de la teoría del conocimiento moderna es que no ha sido capaz de pensar una relación con la objetividad de forma no represiva. La filosofía estuvo embelesada en la espontaneidad del sujeto del conocimiento, y debido a esto procedió a deducir de la inmanencia subjetiva toda exterioridad. Esto no sólo constituyó un error filosófico, sino que también implicó un fracaso de la filosofía como intento de una subjetividad emancipada de la identidad. Y es 
justamente bajo ese interés que Adorno va a someter a crítica toda la tradición gnoseológica buscando un tipo de conocimiento que pueda abrigar la particularidad y lo distinto al sujeto; un modelo de conocimiento como experiencia que no será sólo una experiencia conceptual, sino que tendrá la capacidad de liberar al sujeto de su endurecimiento y de su frialdad, y que a la vez ofrecerá elementos normativos para pensar nuevas formas de relacionarse de los hombres con su mundo.

El problema es que la epistemología moderna no pudo pensar ninguna clase de objetividad sin caer en alguna u otra forma de subjetivismo extremo; es decir, que todo intento de pensar un otro del sujeto en realidad era un encontrar lo que en el sujeto ya estaba. El problema no fue sólo gnoseológico porque esa incapacidad de la tradición de pensar una forma auténtica de objetividad la llevó a no poder dar cuenta de un modelo no reificado de experiencia, que se hacía imperiosa para liberar al sujeto racional de la prisión de su inmanencia y, con esto, desactivar la violencia que tal situación comportaba. Por ende, la pregunta por la objetividad en el marco de la teoría del conocimiento debe ser la pregunta por una forma no reificada de experiencia, la crítica a la relación sujeto-objeto de la epistemología moderna deberá llevarnos a pensar una forma de experiencia sin violencias, es decir, la racionalidad en este planteo tendría que poder ser articulada como experiencia de lo otro que el sujeto.

Este interés por la experiencia en el proyecto "metacrítico" no sólo necesita un planteo materialista, sino también trascendental, tal y como queda de manifiesta en la lectura de Brian O' Connor. Para este intérprete, toda Dialéctica Negativa sería el intento de pensar las condiciones de posibilidad de una experiencia auténtica y, en ese sentido, la crítica a la teoría del conocimiento que allí se lleva a cabo estaría planteada en términos trascendentales:

...haciendo del análisis de la relación sujeto-objeto el centro de su filosofía Adorno puede ser alineado con la tradición trascendental que busca describir no la naturaleza histórica del significado y la experiencia, sino más bien la estructura necesaria y las condiciones de nuestra experiencia. (2004: 173, nuestra traducción). 
Es decir, en Dialéctica Negativa para O'Connor habría una preocupación por reconstruir una teoría de la "estructura general" ${ }^{18}$ de toda experiencia auténticamente filosófica. Lo que Adorno estaría buscando con su crítica a la epistemología es la posibilidad de una experiencia no restringida en términos positivistas o subjetivistas, para pensar formas de subjetividades descentradas y con sus capacidades experienciales potenciadas. Esta lectura de $\mathrm{O}^{\prime} \mathrm{Connor}$ nos dará una buena pista para pensar la vinculación de Adorno con la filosofía alemana y también para encarar el problema de la crítica al sujeto como una reflexión trascendental, donde el intento de conceptualizar una experiencia plena se encontraría en primer término. En este primer apartado intentamos dejar planteado el marco en el que se da el planteo adorniano.

Vemos entonces que: (i) la relación sujeto-objeto debe ser criticada en términos materialistas para que se nos hagan visibles los compromisos ideológicos que su sostenimiento acarrea pero, por otro lado, (ii) que esa relación debe ser ampliada en una teoría de la experiencia que la metacrítica plantea en términos trascendentales. En el siguiente apartado presentaremos el análisis materialista del principio de identidad, dejando el análisis trascendental y la idea de un conocimiento como experiencia para desarrollar en el apartado 3 .

\section{2.- Análisis materialista de la identidad}

Entonces, una vez que vimos cómo esta "metacrítica" está efectuada en términos materialistas como crítica de la sociedad y en términos trascendentales como teoría de la experiencia, veamos ahora cómo se estructura ese sujeto sobre el que Adorno reflexiona. $\mathrm{Si}$, como dijimos, la teoría del conocimiento ha

$18 \mathrm{O}^{\prime}$ Connor agrega un comentario que vale la pena mencionar ya que pone de relieve la importancia de un análisis llevado en términos transcendentales en la medida en que "la filosofía es fundamentalmente una cuestión de cómo entendemos nuestro mundo, es importante apreciar las condiciones estructurales de nuestra interrelación con el mundo. La fundamental importancia de la dialéctica negativa de Adorno es su exitosa valentía de una más profunda conciencia de la estructura sujeto-objeto de nuestros compromisos filosóficos" (2004: 174) 
concebido toda objetividad como una deducción a partir del sujeto o como una identificación que se efectúa a partir de un centro subjetivo; entonces, el concepto que debemos analizar es el concepto de identidad, ya que consideramos que es allí donde Adorno encuentra la característica propia del sujeto de la gnoseología y, a la vez, lo que nos permite relacionar esta crítica con la crítica efectuada en términos de historia natural que expusimos en el capítulo anterior.

Para comprender esto, retrocedamos nuevamente un momento a las consecuencias teóricas del análisis efectuado como "historia natural". Allí habíamos concluido que el proceso de subjetivación racional, que elevó al sujeto a una instancia autónoma, al mismo tiempo acabó por condenarlo. Los impulsos, así como toda dimensión afectiva y sensorial, todo aquello que pudiera ser considerado naturaleza interna, fue reprimido, y el sacrificio que ese sujeto debió realizar se convirtió en estructura internalizada de la subjetividad autónoma. El principio de dominio que en la sociedad primitiva tenía un aspecto inmediato -dominio directo de los clanes sobre el cuerpo del sujeto- fue espiritualizándose cuando el individuo comenzó a asimilar los órdenes sociales como componentes de su psique. Una vez constituido el yo se transformó en el punto arquimédico que estableció la coherencia entre las diversas actividades sociales; de ese modo, el dualismo entre yo y naturaleza terminó por disolver todo el contenido de la experiencia en el sujeto trascendental, y con ello se obtuvo un antagonismo abstracto entre una naturaleza domesticada y un yo vaciado. Al final de esta dialéctica, sujeto y objeto quedaron mutuamente anulados como instancias vivas: el sujeto convertido en sujeto trascendental y el objeto en objeto de conocimiento manipulable. De allí que la crítica como "historia natural" y como "metacrítica" de la teoría del conocimiento converjan.

También en la teoría del conocimiento la relación del sujeto para con el objeto es una relación de identificación, de subsunción de lo heterogéneo al sujeto a sus propias estructuras. Por lo tanto el sujeto es una estructura que encuentra su condicionamiento en el principio de identidad; es tal principio lo que promueve el cierre ideológico y, a la vez, lo que esa forma así cerrada reproduce en todo 
acto teórico o práctico. Este principio de identidad podríamos entenderlo como la traducción en términos filosóficos de lo que anteriormente denominamos autoconservación: si el hombre, como sujeto, en su relación histórico-práctica con la naturaleza se hizo posible sobre el principio de la autoconservación, el sujeto en su relación cognoscitiva con el objeto se hará posible sobre el principio de identidad. El sujeto es siempre entendido como una consecuencia y como una herramienta en la lucha por la supervivencia; y es esta vinculación en la supervivencia biológica, para Adorno, lo que se expresará en toda la filosofía del sujeto desarrollada durante la modernidad, y lo que la crítica deberá develar en términos materialistas. El sujeto racional es siempre entendido como una consecuencia y una herramienta en la lucha por la supervivencia; y es esta determinación en la supervivencia biológica, para Adorno, lo que estará en la base, de modo secreto, de toda la filosofía moderna. Esta correspondencia entre el sujeto de la historia natural y el sujeto de la teoría del conocimiento queda patente en la siguiente cita:

Los carnívoros son animales hambrientos; el salto sobre la presa es difícil, con frecuencia peligroso. El animal necesita para arriesgarse a eso de impulsos adicionales. Estos, junto con la molestia del hambre, se convierten en furia contra la presa, cuya expresión a su vez aterra y paraliza útilmente a la víctima. Mediante el progreso hacia la humanidad (Forschritt zur Humanität) se ha racionalizado esto a través de la proyección. [...]Este esquema antropológico ha sido sublimado hasta el interior de la gnoseología. [ND: 33] (DN: 30).

En la gnoseología, entonces, se sublimarían esos mecanismos que describimos en la historia natural, es decir se proseguirían por otros medios las tendencias a la autoconservación, ahora como agresividad hacia la presa, como violencia del objeto en el conocimiento. Conocimiento y lucha por la supervivencia son aquí instancias que se remiten una a otra en la medida en que el sujeto del conocimiento es emulado a la bestia que, para sobrevivir, debe endurecerse y atacar a su presa. Lo que en el capítulo anterior vimos como autoconservación ahora será analizado como ejercitación de identificación. 
Entonces, en lo que respecta a este principio de identidad, Adorno reconoce la significación equivoca de ese concepto, pero a la vez reconoce que esa equivocidad está dada por algo que pertenece a la cosa. Para que esto quede más claro, será conveniente revisar esta extensa cita de una nota al pie en Dialéctica Negativa:

La palabra 'identidad' (Identität) ha tenido varios sentidos en la historia de la filosofía moderna. Primero designó la unidad de la conciencia personal: de un yo que se conserva como lo mismo en todas sus experiencias. Eso es lo que significa el kantiano "yo pienso que debe poder acompañar todas mis representaciones". Luego de nuevo, la identidad debía ser lo legalmente igual en todo ser dotado de razón (in allen vernunftbegabten Wesen), el pensamiento como universalidad lógica; además, la igualdad consigo mismo de cada objeto del pensamiento (Denkgegenstanden), el simple A=A. Por último, en la teoría del conocimiento: la coincidencia del sujeto y el objeto que siempre se encuentran mediados. [ND: 145] (DN: 146)

Vemos entonces que el concepto de identidad toma diversos significados: a) la identidad psíquica como identidad de la conciencia que perdura a lo largo del tiempo y que asegura asimismo la continuidad de las percepciones; b) la identidad metodológica en forma de legalidad científica, que se manifiesta en la comprensión positivista de la ciencia moderna. Y, c) la más recurrente de todas, la identidad como identidad lógica, cuando las categorías del conocimiento subsumen la multiplicidad de objetos en una forma única general. La primera de ellas la analizamos en el capítulo anterior cuando vimos cómo el yo estaba instituido en el proceso de una historia como un producto de represiones en función del dominio de la naturaleza. La segunda y la tercera forma de identidad -la identidad metodológica de la ciencia y la identidad lógica del concepto- están estrechamente relacionadas pero no son directamente reducibles una a otra, en este capítulo vamos a ver sólo la identidad conceptual. Haremos algunas referencias ocasionales a la identidad de la legalidad científica cuando sea indispensable. 
Estas formas de identidad ocasionarán ciertas ilusiones ideológicas de carácter idealistas que van a caracterizar a toda filosofía subjetivista del conocimiento: 1) otorgará la ilusión de la igualdad de lo diferente: el sujeto al determinar conceptualmente homogenizará lo múltiple violentando la particularidad de lo que intenta conocer; 2) ocasionará la ilusión de que hay un dualismo entre pensamiento y realidad: la esfera del sujeto quedará escindida de toda objetividad y sólo será capaz de abrigar relaciones de dominio y clasificación con esta; 3 ) propiciará el ideal de adecuación teórica de la cosa a su concepto como criterio de verdad y la única relación cognoscitiva válida será un relación teórica; es decir, una relación llevada a cabo desde las categorías del entendimiento en la que el objeto debe amoldarse a las imposiciones cognitivas del sujeto; 4) provocará una reificación del concepto, esto es la ilusión de que el concepto es algo real: es decir, el sujeto a ser origen y fundamento no podrá entablar un proceso de autorreflexión sobre sus propios conceptos ni podrá corregir sus propios esquemas; 5) provocará la ilusión propia de la prima philosophia, la idea de algo primero que actúa como principio y fundamento del pensamiento. Estas características (igualación lógica, criterio adecuacionista de verdad, teoreticismo, dualismo pensamiento-realidad, reificación del concepto y fundacionalismo) son las características del pensamiento idealista y son, a su vez, formas de ilusión construidas ideológicamente que la crítica debe desbancar. Esta breve y sumaria enumeración de auténticos problemas filosóficos nos indican que comprometerse con una filosofía subjetivista implica comprometerse con todas estas ideas; ideas que sólo podrán ser desterradas una vez que la relación sujeto-objeto no se entienda sólo en términos de identidad.

En términos de una crítica a la teoría del conocimiento la identidad también posee implicaciones lógicas en tanto homogeneización y subsunción de la multiplicidad de objetos dados a la experiencia. Pero en este análisis la identidad no se relacionaría con una historia evolutiva como vimos que era el caso de la autoconservación en el capítulo anterior, sino que más bien estaría asentado en ciertas estructuras sociales, o mejor dicho en las formas estructurales de la racionalidad social. En este sentido es que Adorno entiende la identidad tal y como 
Lukács había entendido las antinomias de la filosofía idealista: como sedimentación de relaciones que se producen históricamente. Una lectura que acentúa este aspecto es la que ofrece Frederic Jameson en un interesante trabajo sobre Adorno en el que intenta diferenciarlo de las filosofías posestructuralistas, posmarxistas, posmodernistas con las que muy usualmente se lo ha vinculado ${ }^{19}$. Para esto Jameson emprende una relectura de Adorno acentuando su aspecto materialista en tanto replantea el principio de identidad vinculándolo con las condiciones económicas de producción y reproducción social asentadas en el intercambio mercantil. Argumenta Jameson que el pensamiento de Adorno se encuentra atravesado por el sentimiento de que:

La 'relación de intercambio' es el otro gran leitmotiv que atraviesa la obra de Adorno, y es estrictamente idéntico al leitmotiv más filosófico denominado identidad [...]. La evocación filosófica y antropológica de la voluntad de dominio inherente al concepto idéntico deja paso a un sentimiento más intenso de las coacciones del sistema económico (la producción de mercancías, el dinero, la fuerza de trabajo) inherente de una manera secreta, a todas las manifestaciones de la identidad misma; entretanto, esta infraestructura del concepto deja en claro por qué sus efectos no pueden borrarse simplemente por medio de un pensamiento mejor, por nuevas formas de filosofar, o por medio de conceptos más adecuados. La historia ya piensa al sujeto pensante y se inscribe en formas por medio de las cuales debe por fuerza pensar. (Jameson; 47-48) ${ }^{20}$.

Esta cita nos deja ver que aquella "voluntad de dominio" evocada en términos antropológicos ahora "deja paso" a la relación que se da entre identidad y las coacciones del sistema económico en la estructura del sujeto. Así Jameson da cuenta de un momento materialista opuesto al idealismo en tanto trata de develar los conceptos mostrando la centralidad de las relaciones sociales. En esta cita

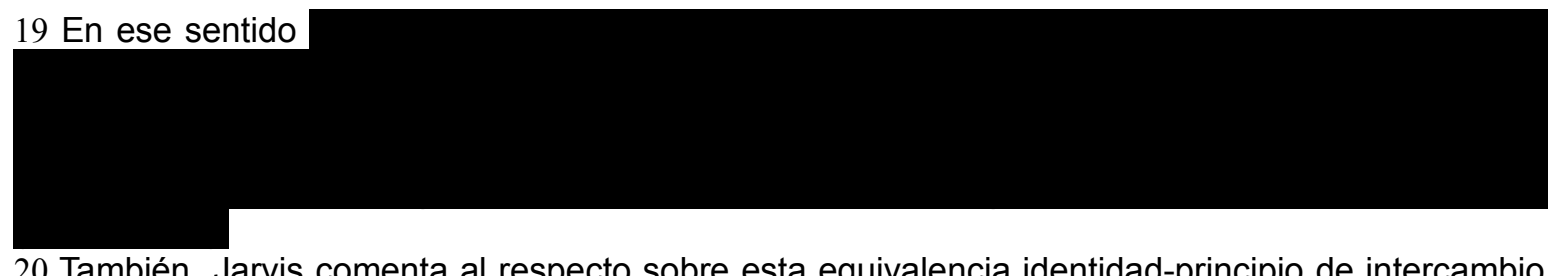

20 También Jarvis comenta al respecto sobre esta equivalencia identidad-principio de intercambio mercantil: "El pensamiento identificatorio no es sólo un error intelectual, ni un problema puramente lingüístico o lógico. No es menos importante para el concepto de identidad de Adorno que el análisis de los juicios predicativos de Hegel, es el análisis del fetichitismo de la mercancía de Marx. En el intercambio económico Adorno encuentra el epítome de un juicio identificatorio" (2004: 167). 
vemos cómo el momento antropológico asentado en el concepto de autoconservación da lugar a otro momento económico-filosófico asentado en el concepto de intercambio mercantil. Según esta nueva perspectiva, podríamos decir que existe en Adorno algo así como una "determinación en última instancia de lo económico", pero no en el sentido de una esfera separada autonomizada de la vida social que interviene en un conjunto de sobredeterminaciones como "determinación en última instancia"; sino que es la forma de racionalidad del intercambio mercantil lo que se reproduce en las estructuras tanto del sujeto como en su actividad conceptualizante. En ese sentido, lo económico para Adorno es más una estructura formal que una esfera institucionalizada, es más una forma de racionalidad homogeneizadora y formal que una instancia precisa. Lo "económico" no se limita a influir externamente, sino que se reproduce en sus mismas condiciones de existencia, en el sentido lukacsiano de aludir a formas de racionalidad social que traspasan los conceptos filosóficos con los cuales se piensa esa misma sociedad.

Sin embargo, y contrariamente a lo que plantean algunas lecturas ${ }^{21}$, no es la esfera de la producción la que tiene prioridad para Adorno, sino la esfera de la circulación como un marco en el cual las relaciones lógicas que se encuentran al interior de la mercancía (abstracción del trabajo, igualación de una mercancía con

21Esta sobre representación de la producción es una de las críticas centrales de los frankfurtianos más jóvenes a la primera generación de la Teoría Crítica, y a Adorno en particular. El problema sería la retraducción de los supuestos productivistas de Marx en términos filosóficos. Para Wellmer (al igual que para Habermas y Honneth) en Marx

es decir suplantarían la teoría del valor trabajo por una teoría de la objetivación o de una razón instrumental, y con esto habrían convertido ese productivismo que en Marx era restringido al análisis empírico de la sociedad capitalista a una "clave de aplicabilidad universal al servicio de una hermenéutica crítica-ideológica del mundo social vital, sustrayéndola así de una vez por todas de una crítica científica” (Wellmer, 1979: 153). Pero esta derivación filosófica de la teoría del valor en una crítica de la razón instrumental no trastocó las bases productivistas y evolucionistas de la teoría de la historia, lo que le impediría a Adorno ver la autonomía de las luchas ideológicas y sociales que se producen en el seno de las instituciones existentes. Esta crítica al productivismo de la primera generación de la teoría crítica será sostenida por toda la generaciones más jóvenes de frankfurtianos como ya vimos, igualmente en Haber 
otra, cuantificación en su relación con un equivalente universal) van a adquirir rasgo de universalidad como relaciones lógicas presentes en toda relación social [ND: 348] (DN: 353). Esta interpretación del papel de lo económico en la constitución de la identidad indica que, las antinomias del idealismo y el carácter dominador del sujeto, no podrán ser reconvertidos si no son reconvertidas las prácticas y las estructuras económicas mediante las cuales la sociedad se reproduce. Esto implica reconocer que esa "infraestructura" del concepto es una abstracción que se reproduce objetivamente y que no puede ser negada por una simple decisión teórica o por una toma de conciencia. Para Adorno la universalidad del sujeto trascendental es la del contexto funcional de la sociedad, la de un todo constituido a partir de las espontaneidades y cualidades singulares cohesionadas mediante el principio nivelador del intercambio mercantil [ND: 310] (DN; 312). Por lo que el sujeto es así la estructura en la que persisten las espontaneidades individuales $\mathrm{y}$, a la vez, la estructura que reproduce y en la que se reproducen las relaciones sociales mercantiles.

Entonces, la identidad tal y como Adorno la entiende guardaría una doble condicionalidad, o mejor dicho representaría una doble traducción conceptual: por un lado es una traducción teórica de la autoconservación biológica como vimos a propósito de la "historia natural" en el capítulo anterior, pero, por otro lado, es una traducción de la estructura económica de la sociedad como parece deducirse de las anteriores observaciones. El problema es que en Adorno no parece estar claro cómo estos momentos puedan amalgamarse, es decir cómo podría relacionarse una práctica biológicamente necesaria -la autoconservación- y una actividad que se reproduce en el ámbito económico -el principio del intercambio mercantil-, entre lo filogenético y lo histórico. Por supuesto que no podría satisfacernos una solución que afirmara que las estructuras del capitalismo están dadas en el mapa biológico de los hombres, o que la conservación vital de la humanidad necesariamente implica la organización capitalista; es decir no podría satisfacernos una respuesta que implicara alguna naturalización del capitalismo. Si bien este problema que estamos planteando aquí no está planteado explícitamente como problema en la obra de Adorno, tampoco consideramos que 
su obra acepte una implicación necesaria y naturalista entre condicionamientos biológicos y capitalismo. Este doble estatus de la identidad como autoconservación e intercambio es un problema que consideramos se deduce de la obra de Adorno, pero para el cual no vemos allí una respuesta acerca de qué tipo de relación habría entre ambas instancias. Por lo tanto, el trabajo de responder esto deberá correr por nuestra cuenta como un argumento "más allá" de Adorno.

Ensayemos entonces una respuesta a este problema. El intento de amalgamar el estatus biológico y el estatus económico de la identidad es un problema sólo si la identidad se concibe literalmente como un "principio", es decir si se concibe como una estructura originaria que determina otras estructuras y que, en tanto estructura originaria o principio, permanece independiente de ellas; por ejemplo, en tanto se piense que lo biológico o lo económico -en la medida en que actúan como principio de la identidad- determinan las demás esferas de la vida social. Consideramos entonces que el problema está en concebir a la identidad como un principio o como una estructura en un sentido originario o fundacionalista. La crítica adorniana a la prima philosophia apunta justamente a impugnar ese modo de pensar que postula un principio primero garante y axioma de toda relación con el mundo. Pero si la identidad no es un principio -en el sentido de una instancia que permanece separada en una relación de fundamentación con respecto a otras instancias- entonces ¿cuál es su estatus?.

Como hipótesis considero que debemos entender la identidad con el carácter de una práctica o de una "regla" para la consecución de nuestras acciones sea acciones morales, cognitivas, económicas, políticas, etc., de modo que, y como Adorno dice a propósito de la identidad, "su significado implica su relación con aquellos actos" [MKT: 96] (MTC; 100). En la medida en que los hombres interactúan con otras personas de forma cosificada, en la medida en que objetivan sus experiencias según los patrones sociales de comportamiento, en la medida en que elevan el conocimiento científico a única norma del conocimiento, en la medida en que subyugan el plano de lo sensible en la construcción de su 
mundo social, etc. producen, reproducen, crean y recrean el principio de identidad. La identidad es inmanente a las prácticas de los sujetos y no un algo o una estructura que esté por fuera de las mismas. Es en este sentido como lo entiende Rusconi:

El principio de identidad no es, por lo tanto, un modo de ser sino una regla acerca de cómo se debe pensar, la cual, separada de los actos individuales y concretos por los cuales ha sido creada, pierde su sentido. (Rusconi; 216-217) 22

La identidad no es una cosa o una estructura legal pero actúa como tal en la medida en que nuestros actos se mueven sobre este "principio" como su regla. Sin embargo, esta lectura no debe hacernos creer que la identidad, como norma inmanente a nuestras prácticas, sea algo que esté siempre disponible para la tematización por parte de los sujetos. Por el contrario, la identidad es algo que se mantiene sustraído en la medida en que es la forma mediante la cual efectuamos nuestro comportamiento económico, conceptual y biológico, pero que es inherente a esos comportamientos. La identidad es para los hombres algo más que una evidencia del mundo social, es el mecanismo mediante el cual las personas construyen esas evidencias. No es el universo ideológico, sino la forma en el que ese universo es construido. Por eso la identidad queda siempre fuera de toda tematización, precisamente por ser el mecanismo de esa tematización.

Debido a esto, la lectura que acentúa el carácter práctico de la identidad es correcta en la medida en que describa la identidad como inmanente a las prácticas; pero incorrecta en tanto pretenda que su inmanencia implica una visibilidad siempre disponible para los sujetos. La identidad atraviesa la sociedad y actúa como una suerte de a priori históricamente constituido que garantiza el funcionamiento del pensamiento, a la vez que se reproduce objetivamente con aquel, de modo que "la apariencia de identidad habita en el mismo pensamiento (Denken) al interior de su forma pura. Pensar (Denken) significa identificar" [ND:

22 En el mismo sentido esta cita de un trabajo de Hammer: "en Adorno (como también en McDowell) la relación entre sujeto y objeto, entre la mente y su mundo, está fundamentalmente formada por nuestra participación en actividades y prácticas lingüísticas compartidas. Ni es el sujeto a-histórico en el sentido de la Bewusstseinsphilosophie, ni pueden los pensamientos tener relación con una objetividad en el mundo apartada de sus relaciones a intuiciones que ya tiene un contenido conceptual." (2000: 87). 
17] (DN: 13) desde los orígenes mismos de la subjetividad. La identidad sólo vale en la medida en que los sujetos actúen conforme a ella, en la medida en que las prácticas de conceptualización lo entronicen como principio. De modo que, la identidad es un principio en la medida en que es considerado como tal en la práctica de los sujetos; no es un modo de ser, ni una estructura objetiva que actúa por sobre la cabeza de los individuos, sin embargo no puede ser visibilizado por simple voluntad o en el marco de la actuación de esas prácticas porque es el mecanismo de toda visibilización.

Este es el momento ideológico de la identidad, en la medida en que en toda conceptualización el intelecto avanza mediante la identificación de las singularidades bajo un enunciado general, y con esto toma un presupuesto ilegitimo: supone que existen casos idénticos. Pero esto tiene consecuencias más profundas que su ilegitimidad lógica: el mundo queda a disposición de un sujeto todopoderoso, que actúa como dador de sentido y define los ámbitos objetuales según sus estructuras subjetivas sin respetar la singularidad del objeto. Un ejemplo por antonomasia de este modo de pensar es, según Adorno, la lógica matemática, que como una malla formal lanzada sobre el mundo, sólo puede proceder convirtiendo a la naturaleza en un espacio repleto de relaciones funcionales cuantitativamente determinadas. Así, el modo de enfrentar el mundo propio de las ciencias naturales, basadas en esa lógica matemática, queda hipostasiado como modo propio de todo conocimiento y de toda delimitación de la realidad. Incluso ya en la base numérica de la matemática, en el número, estaría para Adorno contenida la identidad: "Los números son organizaciones que hacen conmensurable lo no-idéntico bajo el nombre de lo mucho para el sujeto (unter dem Namen des Vielen dem Subjekt), modelo de la unidad. Estos llevan la multiplicad de la experiencia (Mannigfaltige der Erfahrung) a su abstracción" (MKT: 18; MTC; 18). La identidad de este modo funciona como criterio ontológico que determina lo que es real y lo que no; pero, como dijimos, no como un dado en sí, sino sólo en la medida en que el pensar matemático o lógico funcione como criterio de las prácticas cognitivas de los sujetos. 
Ahora bien, en una cita anterior vimos que para Adorno también "pensar significa identificar", y esta observación nos pone otra vez ante el carácter dialéctico de la reflexión adorniana ya que no habría por lo tanto una imputación a la identidad como tal, sino a la postulación de la identidad como único principio rector de coda conceptualización y de toda relación con el mundo. Al perseguir la identificación de todo objeto la racionalidad se convierte en irracionalidad que puede ver que "la desaparición de su propio sustrato [...] es su propio producto, obra de su abstracción" (Op. Cit.). Pero Adorno entiende que el salto por fuera de la identidad debe realizarlo la crítica acentuando aquellos momentos que se sustraen a la identificación. Para fundamentar tal cosa Adorno va a tratar de pensar un conocimiento como experiencia. Entonces habiendo visto el tratamiento materialista del principio de identidad que estructura al sujeto, veamos ahora lo que concierne a la estructura interna de la experiencia que Adorno desea pensar.

\section{3.- La estructura trascendental de la experiencia}

Entonces, una vez realizadas las anteriores observaciones sobre el carácter ideológico del "principio de identidad", veamos ahora cómo debe proceder la crítica de la relación filosófica sujeto-objeto. Lo que aquí tenemos que mostrar es 1) la relación dialéctica entre sujeto- objeto como estructura del conocimiento que Adorno va a tomar de Hegel; 2) la idea de prioridad del objeto que Adorno va a tomar de Kant y que le dará un carácter trascendental a su argumentación, y 3) la necesidad de ampliar lo que entendemos por conocimiento hacia los elementos somáticos intervinientes, de modo tal que el conocimiento pueda ser considerado como experiencia íntegra, y nos ayude a pensar una apertura de ese contexto de "frialdad burgués" en tanto ethos filosófico de Auschwitz.

1) Decir que el conocimiento es una experiencia implica pensarlo en su carácter procesual; es decir, no debe ser entendido como una captura fotográfica de una realidad exterior ya estructurada, sino más bien como un proceso de mediación entre dos polos que no se subsumen uno en otro. El conocimiento no 
identificante entonces debe ser descripto como un movimiento dinámico en el que los peligros de la identificación absoluta sean neutralizados. Para tal cosa debemos concebir el conocimiento como una experiencia que pone en tensión y hace actuar a toda la estructura del sujeto, como una instancia que no culmina en la identificación, sino que persigue también la desestructuración del sujeto identificante. El modelo para pensar un conocimiento en este sentido Adorno lo encuentra en Hegel, particularmente en su magistral exposición de la estructura de la experiencia de la conciencia en la Introducción a la Fenomenología del Espíritu. Veamos en qué consiste esto. En su "Introducción" Hegel trata de describir el proceso de conocimiento en tanto experiencia de la conciencia como un constante acomodamiento de la conciencia al objeto. Lo que caracteriza a la conciencia hegeliana es la idea de que el saber es el movimiento de trascenderse del concepto al objeto. De este modo, la conciencia emprende en el conocimiento un vía crucis en el que va a encontrar constantemente su objeto como inadecuado e insuficiente. $Y$ es justamente esta desigualdad, esta no-identidad del objeto con respecto a su concepto, la condición de posibilidad del desarrollo del conocimiento como experiencia. Es esta estructura básica lo que Hegel describe como experiencia:

Este movimiento dialéctico que la consciencia lleva a cabo en sí misma, tanto en su saber como en su objeto, en cuanto que brota ante ella el nuevo objeto verdadero, es propiamente lo que se llamará experiencia. (Hegel, 2007: 58)

Esta experiencia no puede ser reducida simplemente a sus términos cognitivos, sino que implica una violencia total a las estructuras de la conciencia, en la medida en que "la conciencia se ve impuesta por sí misma esta violencia que echa a perder en ella la satisfacción limitada" (Op. Cit.). Por eso la filosofía debe ver "si el concepto corresponde al objeto y si el objeto corresponde a su concepto" (Ibídem.: 57). Si bien la conciencia no puede ser separada de lo que para ella es su objeto, en Hegel esto se da como descubrimiento, por parte de la conciencia, de que lo que ella creía como un objeto no es más que su propia verdad. El saber de la ciencia acerca de lo verdadero va cambiando y con ella cambia la conciencia misma y cambia el objeto que tiene ante sí. Aquello que la conciencia tenía como 
un en sí, como si fuera lo verdadero absoluto, queda descubierto en este proceso como algo que únicamente era en sí para ella, "tal es precisamente el resultado de la experiencia: la negación del objeto precedente y la aparición de un objeto nuevo que, a su vez, origina un nuevo saber" (ibídem.: 59). Así concebido, el conocimiento es tanto el descubrimiento de mundos nuevos como corrosión progresiva de las estructuras solidificadas del sujeto. El conocimiento está analizado en su devenir otro, en la experiencia de una transformación incesante en la que cambian las estructuras del sujeto y en el que también se transforma el objeto que tiene ante ella. O como dice en su célebre estudio Jean Hyppolite:

En esta distinción Hegel asimila la experiencia que hace la conciencia a una dialéctica pero, a la inversa, nos hace comprender cómo la dialéctica, principalmente en la Fenomenología, es propiamente una experiencia. (1991: 25).

Pero en Hegel todo este proceso ya está presupuesto en el saber del filósofo que se da como Saber Absoluto y que opera como garantía de la perfecta consumación de la identidad entre sujeto y objeto. Es justamente esta resolución como identidad de la dialéctica lo que Adorno cuestiona de Hegel [DH: 307-309] (TH: 23-26).

2) Para evitar el riesgo del cierre de la dialéctica Adorno confrontará críticamente el esquema de la gnoseología idealista según la idea de "prioridad del objeto". Esta idea puede ser entendida como una "hoja de ruta" de la crítica para pensar ese modelo de experiencia ampliado que buscamos. La tesis de Adorno es que el objeto es irreductible al concepto configurado sobre el principio de identidad, por esto, para dar cuenta de esa irreductibilidad, es que formula la exigencia de una "prioridad del objeto". Tal exigencia pone el acento en la "no-identidad" que está presente en todo acto intelectivo y en toda relación sujeto-objeto, no-identidad que el idealismo intentó por todos los medios acallar y que la crítica ahora debe darle voz. Esta idea de primacía del objeto en el fondo intenta responder a la pregunta de cómo podemos liberar al sujeto encerrado y 
endurecido para hacerlo capaz de abrigar experiencias nunca antes experimentadas, no codificadas, particulares.

La confianza de Adorno es que el objeto es algo más que el simple resultado de la determinación conceptual de un sujeto, o es algo más que el "resto" que queda disponible una vez se ha llevado a cabo el ejercicio de eliminar los componentes parciales subjetivos. Esto no debe confundirse con la defensa de un realismo ingenuo, sino que lo que aquí se pretende es evitar que las experiencias sean enteramente explicadas desde las solas determinaciones de la conciencia. Adorno cree que la experiencia sólo puede ser explicada si es que existe un objeto irreductible a la conciencia, y es en ese sentido que la idea de "prioridad del objeto" puede ser comprendida como parte de un argumento trascendental, tal y como vimos que la lectura de O'Connor sugería. Es decir, para que seamos capaces de abrigar experiencias y de producir un conocimiento no identificante, es necesario algo que quede por fuera de nuestra conciencia que pueda servir como referencia. Este argumento en alguna medida se sostiene en la necesidad de la cosa en sí de la filosofía kantiana como necesidad de un criterio externo que asegure la continuidad de las representaciones. Veamos brevemente este argumento kantiano e indaguemos su relación con la filosofía adorniana.

En la sección "Refutación del Idealismo" Kant va a confrontar con todas aquellas posiciones que niegan el carácter externo de los objetos de la conciencia, en especial con lo que denomina "idealismo problemático" que sólo tiene certeza del sujeto y duda de la existencia del mundo externo, en clara alusión a Descartes. Lo que Kant va a refutar allí es la idea de que sea posible la experiencia interna a la certeza de un ego sin apelar a algún tipo de experiencia externa, que a su vez supone la existencia de un mundo externo. El argumento de Kant es el siguiente:

Tengo conciencia de mi existencia como determinada en el tiempo. Toda determinación de tiempo supone algo permanente en la percepción. Ahora bien, este permanente no puede ser algo en mí, puesto que no es sino mediante este permanente como puede precisamente ser determinada mi existencia en el tiempo. (Kant, 2010: 231)

Por lo tanto, dada la conciencia exterior y la necesidad de una exterioridad que actúa como parámetro de ella, entonces: 
La determinación de mi existencia en el tiempo no es posible sino mediante la existencia de las cosas reales que percibo fuera de mí. Ahora bien, la conciencia en el tiempo está ligada necesariamente a la conciencia de la pasibilidad de esta determinación en el tiempo. Está pues, ligada también necesariamente a la existencia de las cosas fuera de mí, como a la condición de la determinación de tiempo; es decir que la conciencia de mi propia existencia es al mismo tiempo una conciencia inmediata de la existencia de otras cosas fuera de mí. (Ibídem.: 232)

Según la naturaleza de la experiencia externa que tenemos, podemos ser conscientes de la secuencia temporal de dicha experiencia. En otros términos, la característica más notoria de la conciencia empírica es su determinación en el tiempo. Pero esta permanencia en el tiempo de mi conciencia supone algo permanente en la percepción, ya que Kant no confía en que el trascendental "yo pienso" que acompaña a todas mis representaciones o las formas de intuición sensible puedan proveer los elementos permanentes que garanticen la continuidad temporal de mi conciencia. Es decir, el sujeto no posee el criterio de lo permanente en tanto sea sólo una serie de experiencias en un nivel empírico, por lo tanto necesita un criterio que sólo puede provenir de afuera de él, como mundo externo. De este modo, en Kant la existencia de los objetos del mundo exterior no se derivan de su ser experimentado, sino de forma trascendental como condiciones de posibilidad de nuestra conciencia interior.

Pero este argumento no intenta analizar cuáles son los modos precisos en que estos objetos externos se relacionan con nuestras representaciones de ellos, sino simplemente probar por vía trascendental la necesidad de su existencia. $O$ 'Connor señala que Adorno sigue a Kant cuando confía que la noción de una experiencia siempre presupone la existencia de un objeto exterior, pero como una relación que no está determinada categorialmente, ya que no se presenta como una relación precisa entre un concepto determinado y un objeto determinado, sino como necesidad trascendental de que tal relación exista (O'Connor, 107). Sin embargo, la no conceptualidad de esta relación no cae por fuera del espacio de la razón en la medida en que su existencia puede ser demostrada mediante argumentos filosóficos; es decir, no pertenece a la esfera de lo místico sino que puede ser conceptualizada. Tal cosa es lo que Adorno intentará llevar a cabo: no 
buscará ofrecer ejemplos específicos de experiencias consumadas, sino analizar la estructura trascendental de una experiencia verdadera; esto es, de una experiencia que logre una relación de no identificación del sujeto para con el objeto, y de no subsunción del sujeto en el objeto.

De este modo, en el conocimiento, concebido como experiencia el pensamiento, se encontraría con una realidad no enteramente reducible. En este planteo el sujeto sería crucial para la experiencia pero sin constituir, sin embargo, la totalidad de la experiencia. Una experiencia no reificada sería una que liberaría al sujeto de la celda de su propio encierro y, a la vez, le permitiría pensar la particularidad de un objeto que no se deja reducir a sus categorías. En este marco, experiencia es el proceso en el cual el sujeto podría, con todas sus potencialidades, ser afectado por algún aspecto de la realidad y de ese modo verse transformado. Es decir, la experiencia tiene como condición la apertura, reciprocidad y transformación tanto del objeto como del mismo sujeto. Para tal cosa es necesario un mundo exterior que pueda afectar y transformar al sujeto, pero en Adorno ese mundo exterior que es condición de posibilidad de mi existencia no corresponde exactamente a la noción de "cosa en sí" kantiana, entendida como esfera incognoscible, como límite irracional, tal y como quedaba planteada en la lectura lukacsiana de Kant; sino que, Adorno lo piensa bajo la categoría de lo no-idéntico, categoría que alude a un objeto no completamente conceptualizable, pero que no permanece por fuera de toda esfera racional.

Entonces, si pensamos esta "prioridad del objeto" como una cosa en sí kantiana la posición de nuestro autor no estaría muy lejos de ciertos planteamientos nietzschieanos, planteos que llegarían a rechazar el mismo concepto de racionalidad. Veamos esto. En un texto temprano llamado "Sobre verdad y mentira en sentido extramoral" (1873) Nietzsche se refiere al mecanismo de formación de conceptos de un modo muy similar al planteado por Adorno:

Toda palabra adquiere inmediatamente categoría de concepto por la circunstancia de que no ha de servir para recordar la experiencia primitiva, única y específicamente individual que le ha dado origen, sino ha de corresponder a innumerables casos más o menos análogos, es decir, nunca rigurosamente iguales, en una palabra, a un sinfín de casos entre los cuales no hay ni dos que 
sean iguales. Todo concepto se origina en virtud de un acto del hombre consciente que concibe como iguales cosas que no son iguales. (1970: 545)

Es decir, al igual que en Nietzsche, el problema del pensamiento identificante radica en que subsume una multiplicidad en una unidad de forma dogmática o imperativa, el sujeto cosificado según el principio de identidad pierde aquella variedad de determinaciones del objeto. Sin embargo, la crítica adorniana se aleja de la nietzscheana, y con ello de toda la crítica posestructuralista al pensamiento conceptual ${ }^{23}$, en la medida en que no aceptaría la siguiente afirmación con la que Nietzsche continúa:

Pasando por alto lo individual y concreto, obtenemos el concepto, así como por lo demás la forma, siendo así que la Naturaleza no sabe de formas ni de conceptos, ni tampoco, por consiguiente, de especies, sino tan sólo de una $\mathrm{X}$ inaccesible e indefinible para el hombre. (Op. Cit.)

El punto aquí se presenta más problemático aún en la medida en que para Adorno lo que se opone al sujeto conceptual no es una " $x$ inaccesible e indefinible para el hombre". Para él no se trataría de una contraposición entre generalidad del concepto o particularidad del objeto, determinación categorial o inmediatez pura, sino que ve estos términos en un espacio dialéctico en el que ambos son mediados mutuamente sin llegar a una identificación plena, y en el que el objeto aparece ya como entrelazado con otros objetos en diversas redes. En Adorno no está la idea de un caos puro que se mueve por debajo del pensamiento conceptual y que este no puede nunca localizar ni aferrar. Para él tanto la facticidad desnuda, como ese caos que escaparía a las redes conceptuales, o la propia inmediatez del Ser serían abstracciones que no estarían siendo conscientes de los procesos de mediación ya consumados. Lo particular es pensando por Adorno no como un en sí, sino dentro de un conjunto de relaciones históricamente sedimentadas con otros particulares donde estaría la definición

23 Un interesante análisis y que en parte aquí seguimos se encuentra en Dews (2003). Allí el autor realiza la siguiente afirmación en contra de la asimilación a las filosofías posestructuralistas: "el concepto de reconciliación de Adorno, si bien no está exento de críticas, no puede ser considerado como simple desliz de su parte, ni mucho menos como una invitación al totalitarismo, para contrastarlo con la visión firme y menos transigente del posestructuralismo" (2003: 57). Esta acentuación del concepto de reconciliación implica la acentuación de un momento de verdad en aquello sometido a crítica, y es esa insistencia en el rescate de los conceptos de ese momento liberador lo que para Dews distanciaría a Adorno de los postestructuralistas. 
-contingente- de su identidad. Por eso, la prioridad del objeto no significa para Adorno inmediatez objetiva, ni tampoco una $x$ como absoluta alteridad, sino que es prioridad dada al objeto significa "la progresiva diferenciación cualitativa de lo en sí mediado, un momento de la dialéctica que no está más allá pero que se articula con ella." [ND: 75] (DN: 82).

En este sentido, Foucault dice sobre Nietzsche una frase que también lo representa y que está muy lejos de poder ser atribuida a la crítica adorniana al conocimiento: "según Nietzsche no hay en realidad ninguna semejanza ni afinidad previa entre el conocimiento y aquello que sería necesario conocer" (Foucault, 2010: 22). Para Adorno una heterogeneidad tan radical entre pensamiento y realidad, entre fijeza del concepto y devenir del mundo es inaceptable. El problema entonces no estaría tanto en postular una otredad absoluta caracterizada como singular, diferencia, flujo, indeterminación, devenir, sino en abolir las jerarquías, en destronar el sujeto de su centralidad, pero no para colocar luego un objeto revestido de aquellas características, sino para promover una relación de no dominación, sin jerarquías ni violencias. De modo que:

la situación reconciliada (versöhnte Zustand) no anexaría lo ajeno al imperialismo filosófico, sino que tendría su felicidad en que lo lejano y distinto se quede en la cercanía concedida, más allá tanto de lo heterogéneo como de lo propio. [ND: 192] (DN, 192).

Esta difícil relación de heterogeneidad y cercanía que exige la "situación reconciliada" es un tanto difícil de concebir, y Adorno no ofrece ejemplos concretos de una experiencia consumada, porque en parte, y como dijimos, su análisis está efectuado en términos trascendentales: le interesa analizar la estructura que hace posible una experiencia plena y no ofrecer ejemplos empíricos. Veamos entonces cómo piensa Adorno esta experiencia ampliada

\section{4.- Sobre un concepto de experiencia ampliada}

Lo que Adorno quiere pensar es la estructura de la experiencia aludiendo 
trascendentalmente a una relación mediada entre el sujeto y el objeto, relación que sostiene una tensión entre ambos y en la que ninguno de los términos puede ser reducido al otro: es entonces la mediación entre sujeto y objeto lo que constituiría la estructura de la experiencia. Este énfasis en la mediación nos haría ver que el error de la prima philosophia fue postular un principio único y no una relación de elementos como explicación del conocimiento [MKT: 38] (MTC: 56). La apuesta de Adorno por no abandonar el concepto, y con ello el pensamiento racional se muestra claramente en que él considera que es en el mismo concepto donde opera la no-identidad, en la medida en que el concepto adquiere significado sólo en referencia a una otredad, a un objeto que no es él.

Sin identificación es imposible ningún tipo de pensamiento ni de autorreflexión, ya que pensar es determinar y determinar implica identificación. Entonces es esa misma identidad la que tiende a la diferencia, en la estructura del juicio racional ya estarían contenidos los presupuestos para el conocimiento de lo diferente. Para Adorno el problema no es la epistemología en sí misma ni su ideal adecuacionista -el conocimiento como convergencia entre un objeto y el pensamiento-, sino más bien el hecho de que ese ideal fue entendido sólo en términos de identificación. Esta observación que sin dudas tiene cierta carga irónica la desliza Adorno en el siguiente fragmento:

El fallo del pensamiento tradicional es que toma la identidad como su meta. La fuerza que hace saltar la apariencia de identidad es la del mismo pensamiento:la aplicación de su «esto es» hace tambalearse su,sin embargo imprescindible, forma. Además es dialéctico el conocimiento de lo diferente, porque identifica más y de otro modo que el pensamiento de la identidad. Mientras que él pretende decir qué es tal cosa, el pensamiento de la identidad dice bajo qué es subsumido [...]. A través de la crítica no desaparece la identidad, sino que la cambia cualitativamente. Elementos de la afinidad del objeto con su pensamiento viven en él. Aunque sea hybris pretender que la identidad existe de modo que la cosa en sí (Sache an sich) corresponda a su concepto (Begriff), este ideal no debe ser simplemente descartado: en el reproche de que la cosa no es idéntica al concepto vive la nostalgia de que pudiera serlo. [ND: 152] (DN: 152-153)

En la identidad del pensamiento a la cosa hay un momento crítico cuando se hace presente la exigencia de que la cosa debe corresponder a su concepto, 
tanto como que el concepto debe corresponder a la cosa. En esta cita se amplia el ideal de adecuación al ideal de una reconciliación entre dos términos vivos, y es este ideal de reconciliación lo que le permite a Adorno reconocer ciertos elementos normativos en el concepto ${ }^{24}$. La singularidad del objeto le impone obligaciones al concepto, tanto como la universalidad del concepto impone prescripciones a la cosa. Entonces como dijimos, la objetividad que Adorno quiere pensar no corresponde a la cosa en sí kantiana ni a esa $\mathrm{x}$ inexplicable de la que habla Nietzsche, sino a una instancia ya preformada por un cúmulo de experiencias históricas. El objeto estaría ya dado con una carga de significados y sentidos sedimentados que son previos al sujeto y, a la vez, son condición de posibilidad de su capacidad de conocimiento, ya que:

... tal universalidad inmanente de lo singular es objetiva como historia sedimentada. Esta se encuentra en lo singular .y fuera de ello, abarcándolo y dándole su lugar. [...] Sólo un saber que pueda liberar la historia en el objeto es el que posee la importancia histórica del objeto en su relación con un presente distinto. El conocimiento del objeto en su constelación es el conocimiento del proceso que se ha acumulado en él. [ND: 165-166] (DN: 166).

Un ejemplo de lo que implica esta idea de "sedimentación histórica" en el encuentro entre objeto y concepto Adorno lo ofrece a propósito del concepto de libertad. Cuando decimos que fulano de tal es un hombre libre, con el predicado libertad no nos estamos refiriendo a una generalización que abarca a todos los

24 Un comentario de Gillian Rose puede dejar un poco más en claro la relación entre este análisis de la identidad en términos de una teoría del conocimiento y la posibilidad teórica de pensar un horizonte emancipatorios en términos sociales: "[...] que el concepto refiera a su objeto, alude, para él [Adorno], a sus condiciones ideales de existencia. Este es el aspecto utópico de la identificación. Desde el punto de vista del concepto que identifica a su objeto en este sentido implica que el objeto particular debe tener todas las propiedades de su estado ideal. [...] El pensamiento de la identidad implica que el objeto es racionalmente idéntico al concepto. Sin embargo, dado el estado actual de la sociedad, el concepto no puede identificar su objeto verdadero. La conciencia que percibe esto es el pensamiento no-idéntico o dialéctica negativa" (Rose, 1978: 44). Este análisis de la correspondencia ideal entre un objeto y su concepto no está pensado como una defensa de la relación referencialista en el significado sino, como el señalamiento de una dimensión utópica en esa relación. En este sentido "si el objeto es la sociedad, la sociedad tal y como es ahora es un objeto que no puede satisfacer su concepto [...]. Pero aquel concepto es lo que el objeto posee "por sí mismo", es decir, las propiedades que potencialmente tendría. Estas propiedades son lo que "desearía ser". La personificación del objeto supuesto mediante lo que "desea ser" es un modo estilístico de presentar el momento utópico del objeto. [...]. Confrontar el objeto, la sociedad actual, con lo que "él es", esto es, compararlo con las condiciones de su identidad racional, implica ver lo no idéntico en la relación entre el concepto y el objeto" (Ibídem.: 45) 
hombres considerados jurídicamente libres, ese predicado no alude a un concepto formal, construido como una generalización a partir de la acumulación de particularidades, sino más bien un tipo de concepto histórico de carácter enfático capaz de indicar un horizonte normativo que vaya más allá de lo fáctico ${ }^{25}$. Esta idea de concepto normativo o enfático refiere a objetividades histórico-filosóficas que fueron enarboladas con vista a su realización práctica en la historia, como los ideales históricamente construidos de igualdad, libertad o justicia, conceptos objetivos que aluden a un estado de cosas aún no realizado y que por esto son capaces de mantener una imagen utópica como negatividad del orden existente.

Con esta obligación de que el objeto debe satisfacer a su concepto Adorno mantiene la exigencia crítica de una realización histórica de los ideales esbozados por la propia sociedad; a esto alude la frase que abre Dialéctica Negativa: "la filosofía que en algún momento pareció obsoleta, aún se conserva con vida porque se dejó pasar el instante de su realización (Verwirklichung)" [ND: 15] (DN, 11), puesto que "la verdad no significa sólo la conciencia racional, sino también su configuración en la realidad" [DA: 50] (DI: 54). Esos conceptos, originados históricamente, como ya vimos, contienen un momento de verdad ${ }^{26}$ que se escinde

25 Deborah Cook alude a este carácter enfático o normativo del concepto cuando dice: "Surgido en un contexto socio-histórico particular, este concepto además trasciende esa situación en virtud de su contenido de verdad. Como Marx, quien creía que la religión tuvo un contenido de verdad en tanto postulaba un mundo que eclipsa o excede la realidad del capitalismo industrial [...]. Efectivamente, Adorno fue de algún modo más allá que Marx cuando argumentó que el contenido ideacional del concepto no era enteramente una función de su génesis histórica. Afirmar que todo concepto expresa intereses particulares e históricos (de clase) sería extirpar con lo falso, todo lo que fue además verdadero, todo lo que, sin embargo impotentemente, lucha por escapar al confinamiento de una práctica universal, toda quimérica anticipación de una práctica más noble" (Cook, 2006: 8-9).

26 Por supuesto que el concepto de verdad no tiene un sentido objetivo ni trascendente a la historia en Adorno, pero aun así no deja de ser problemático. Podemos hacer valer para Adorno una afirmación que Jay hace para la Teoría crítica en su conjunto: "Si puede decirse que la Teoría Crítica haya tenido una teoría de la verdad, ésta aparecía en su crítica inmanente de la sociedad burguesa, que comparaba las pretensiones de la ideología burguesa con la realidad de su condiciones sociales. La verdad no estaba fuera de la sociedad, sino contenida en sus propias reivindicaciones. Los hombres tenían un interés emancipatorio en actualizar la ideología" (Jay, 1984: 117). En el caso de Adorno esto es cierto, pero un poco más complejo, en la medida en que es consciente de que esa verdad históricamente consumada no puede ser instanciada en el presente, y que debe permanecer como un ideal negativo. En Adorno la idea de verdad siempre tiene un carácter relacional intrínseco con la idea de falsedad y opera en una polaridad regulativa y dialéctica. Cada texto o dispositivo cultural está analizado desde la perspectiva de su verdad y de 
de su condición social y adquieren un valor normativo que trasciende a la sociedad de la cual emergieron.

Es notorio que aquí dimos un salto en la exposición ya que comenzamos en el plano de la gnoseología para pensar una relación cognitiva entre sujeto-objeto y nos desviamos hacia una relación concepto-objeto en un sentido histórico. Pero este salto está justificado en la medida en que, como dijimos, para Adorno "crítica del conocimiento es crítica de la sociedad" y por ende su metacrítica pretende valer también como modelo de crítica social. Esta tesis se asienta en la suposición de que detrás de las estructuras cognitivas se asientan experiencias históricas que se impregnan como formas del acto de conocimiento. Debido a esto la crítica al conocimiento es materialista en el sentido que vimos lo era el análisis de las antinomias del pensamiento de Kant realizado por Lukács. Entonces, tanto el sujeto que Adorno quiere pensar como el objeto están dados en términos históricos, están atravesados por significaciones, por usos y prácticas, por ideales que se van desplegando y que quedan en la estructura tanto de la cosa como del sujeto. La reflexión que comenzó en el plano de la epistemología ahora se desplaza al plano de la historia.

La experiencia que Adorno quiere pensar es una experiencia mediada históricamente, una experiencia en la que los elementos de la totalidad social se van sedimentando en sus materiales. Por lo tanto, aceptar la irreductibilidad de lo particular en la experiencia para Adorno no implica aceptar alguna versión irracionalista de encuentro con una radical otredad, o aceptar una oposición de algo sublime irracional, sino fundamentalmente implica aceptar la necesaria mediación no identificatoria entre sujeto-objeto. Es en el ideal de adecuación de la cosa al concepto que pretende alcanzar donde se encuentran los elementos utópicos, la exigencia de que también el objeto corresponda al concepto. Para

su falsedad: de su falsedad en tanto intenta resolver las contradicciones mediante la imposición del principio de identidad, y como verdad en tanto aspiración a una solución real e histórica de esas contradicciones. El concepto de sujeto es clara expresión de esto: falso en cuanto autónomo con respecto de la naturaleza, verdadero en cuanto condición de posibilidad de la crítica. En ese sentido afirma Rusconi: "Verdad y falsedad en Adorno son dos conceptos que superan su significado intelectualista e introducen una toma de postura ético práctica. Quien decide la $<$ verdad > de la teoría no es la exactitud formal o la adecuación a un estado de cosas, sino la capacidad para situarse polémicamente frente a la realidad" en Rusconi (1969: 223-224). 
Adorno cada objeto subsumido en un juicio identificante posee cualidades que van más allá de ese concepto, este plus del objeto es la condición de su cognoscibilidad: si el objeto fuera solamente lo que el sujeto dice que es no habría conocimiento alguno ${ }^{27}$. Entonces la reconversión del pensamiento de la identidad no vendría dada a partir de un elemento externo, de una instancia mística que permanece como incognoscible, sino en sus mismos marcos, como consumación del ideal del conocimiento en tanto respeto a la particularidad del objeto ya sedimentado históricamente.

Ahora bien, en el plano cognitivo, ¿cómo se daría esta mediación? ¿Qué elementos deben estar presentes para que la experiencia de sujeto y objeto no sea solamente teórica, ni regida bajo los imperativos de una subjetividad identificadora?, ¿cuáles son los elementos que posee la subjetividad para alcanzar una conceptualización no identificante, para abrigar una experiencia ampliada?. Es en el concepto de mimesis en el que Adorno encontrará ciertas herramientas para pensar esta mediación no violenta entre sujeto y objeto. Pero la mimesis es un concepto problemático, no sólo por sus implicaciones irracionalistas sino también porque Adorno nunca ofreció una teoría del mismo, por lo que su problematización por nuestra parte tendrá siempre un carácter hipotético, aunque necesaria para responder a las preguntas planteadas líneas arriba.

En Dialéctica de la llustración Adorno introduce el concepto de mimesis con un sentido antropológico muy ligado a lo que Freud describe como pulsión de muerte en Más allá del Principio del Placer:

Representa una tendencia profunda innata a lo viviente, cuya superación es signo de toda evolución (Entwicklung): tendencia a perderse en el ambiente en lugar de afirmarse activamente en él, la inclinación a dejarse llevar, a recaer en la naturaleza. Freud lo ha llamado instinto de muerte (Todestrieb); Callois, le mimétisme. Tal morbosidad (Süchtigkeit) atraviesa lo que se opone al progreso

27 En ese hiato entre lo expresado y las intenciones, entre el lenguaje y lo que designa pervive la apertura de la dialéctica y lo no-idéntico. En relación al lenguaje dice Bernstein sobre Adorno: "todo aquello que arruine la transparencia conceptual, todo elemento de conceptualización que aparezca en el lenguaje como vaguedad, indeterminación, exceso material o retórico, es la expresión del exceso del objeto en relación a su concepto lógico" (Bernstein, 2004: 42) 
constante, desde el delito que no sabe seguir el rodeo a través de las formas actuales de trabajo, hasta la obra de arte más sublime. [DA: 259-260] (DI; 131).

La mimesis es la irrupción de lo amorfo, lo difuso, lo que socava la identidad del yo mediante lo disgregador de un encuentro no controlado con la naturaleza, es lo que se escapa a las ordenaciones sociales. El asunto es que si bien esta tendencia ofrece la posibilidad de descentrar al sujeto, también representa el peligro de una instancia irreflexiva, por lo que la mimesis por sí misma es incapaz de sostener la distancia necesaria para que sea posible la crítica ${ }^{28}$. Pero lo que a Adorno le interesa de este concepto es su potencial para compensar las tendencias identificantes de la racionalidad en la medida en que esa relación mimética con el objeto podría convertirse en un correctivo para el concepto identificante: "no de otro modo puede el concepto representar la causa de la mimesis que suplantó que apropiándose de algo de ésta en su propio comportamiento, sin perderse en ella" [ND: 26] (DN, 23). Sin embargo, a lo que este concepto aluda, o su significación en una reformulación de la teoría del conocimiento, es una cuestión de difícil resolución en la obra de Adorno, donde no sólo no se encuentra una teoría satisfactoria de la mimesis, sino tampoco indicios claros para llevarla a cabo.

Para Habermas se trataría del "mero impulso, de lo simplemente opuesto a la razón" (Habermas, 2008: 81); para Hammer la mimesis "debe ser entendida en conjunción con la conceptualidad, como una reinscripción de la distinción kantiana entre conceptos e intuiciones" (Hammer, 2000: 86), por lo que se trataría de una reconceptualización de la noción de intuición kantiana; por su parte Papastephanou sostiene que "la mimesis parece estar jugando el rol que es equivalente a lo sublime en Kant, sin la asunción fundamental kantiana del triunfo de la razón pura a través del juicio estético de lo sublime" (Papastephanou, 2000:

28 Un interesante análisis del concepto de mimesis en Adorno pero más ligado a su potencialidad en el plano moral que en el cognoscitivo se encuentra en el libro de Marta Tafalla (2004) Sin embargo allí la autora realiza algunas observaciones sobre lo problemático de este concepto, por ejemplo cuando dice: "Espontánea e irreflexiva, no comprende críticamente la realidad y menos aún desea transformarla. No se abre en la espera de un futuro distinto ni contiene un potencial de transformación, es la mera entrega a la naturaleza tal como es, la imitación, la repetición y la continuación de lo natural" en Tafalla (2003: 133). 
25). Si bien reconocemos que el modo en el que Adorno incluye este momento mimético en su filosofía necesita de una teorización en el que sea puesto al menos en una discusión al interior de la tradición filosófica, consideramos que la mimesis no representa algo simplemente opuesto a la razón, o a una instancia diferenciable dentro de una analítica del conocimiento o dentro la esfera estética, sino que es el recuerdo de lo natural y somático -como placer y sufrimientopresente en el sujeto que abre la posibilidad de redimirlo de sus tendencias imperialistas.

La mimesis en el acto cognoscitivo tendría dos funciones: por un lado, debilitar los límites del yo autónomo e identificador a partir de una revalorización de los momentos naturales -afecciones, placer, sentimientos, pulsiones, etc.- en el conocimiento; y por otro lado, mediante esa naturaleza colocada otra vez en un primer plano, la mimesis debería promocionar una "comunicación sin violencia" con el objeto, en la que el conocimiento "mantendría su felicidad en la cercanía otorgada a lo lejano y distinto, más allá de lo heterogéneo como de lo propio" [ND: 192] (DN; 192). Podemos decir entonces que la mimesis no es algo opuesto al pensamiento racional tal como lo muestra la siguiente cita: "En la tesis de que sólo lo semejante puede conocer a lo semejante el inextinguible momento de la mímesis en todo conocimiento se hace consciente" [ND: 153] (DN; 153). El pensamiento sólo es posible por este momento mimético en la medida en que a través de él pervive algo no-idéntico (no simbolizable) dentro del concepto. Es justamente el momento mimético el encargado de mostrar esta no identidad presente en el concepto de modo que el pensamiento mimético tendría la función negativa de mostrar cómo el objeto es capaz de violentar la identidad que el sujeto intenta imponer. En este sentido Simon Jarvis afirma:

el momento mimético del lenguaje filosófico, sin embargo, no puede ser filtrado de la identificación conceptual y presentado como algo independiente. Eso sólo puede ser iluminado mostrando cómo la identificación identifica erróneamente. (Jarvis, 1998: 178, nuestra traducción) 
Ahora bien, sólo en la medida en que pensemos al conocimiento como una experiencia asentada en una racionalidad sin violencia identificadora podremos pensar la mimesis en términos de "comunicación", "felicidad", "cercanía". El conocimiento resultaría así una experiencia plena del objeto por parte del sujeto, en el que intervendrían aspectos somáticos que ampliarían los cognitivos. Por supuesto que esta epistemología ampliada experiencialmente no encuentra su garantía plena sólo en esta dimensión mimética, ya que esto sería reincidir en otro tipo de identidad: en la disolución del sujeto en el objeto. Pero "el pensamiento crítico no quiere otorgar al objeto el trono vacante del sujeto, en el que el objeto no sería nada más que un dios, sino eliminar la jerarquía" [ND: 182-183] (DN: 183). Por lo tanto, el elemento conceptual es inescindible tanto del conocimiento como de una teoría crítica y de un horizonte emancipatorio, o en palabras de Adorno "la utopía del conocimiento sería abrir con conceptos lo carente de conceptos (Begriffslose) pero sin igualarlo a ellos" [ND: 21] (DN, 21). Pero ¿cómo pensar el modelo de un conocimiento liberado de las cadenas de la identidad?, ¿cómo sería este conocimiento concebido en el sentido de una experiencia, en el que el aspecto somático que la mimesis plantea cobrara relevancia y en el que no existieran ya jerarquías?.

Como dijimos, el conocimiento está pensado entonces como una experiencia en el que son puestas en juego todas las capacidades perceptivas de los sujetos, en el que su conciencia se vea transformada no sólo mediante la acumulación de información, sino también como liberación de los sentidos. En este marco podemos entender la siguiente frase que ya citamos líneas arriba, y que de otro modo sonaría un poco desconcertante: "La idea de una [filosofía] transformada sería acoger lo semejante determinándolo como lo desemejante a ella" [ND: 153] (DN; 153) Aquí no se trataría sólo de percibir lo no percibido, de percibir un objeto enteramente nuevo, sino de percibir lo percibido como lo no percibido, de percibir un objeto como lo enteramente nuevo. No se trataría de cambiar el objeto ni de abjurar del concepto, sino de conseguir una perspectiva del objeto de modo tal que nuestra experiencia de él se transforme. En Mínima 
Moralia Adorno realiza una observación que consideramos vale como ejemplo para ese "percibir lo semejante determinándolo como lo desemejante":

Al niño que regresa de las vacaciones, su casa le parece nueva, fresca, festiva. Pero nada ha cambiado en ella desde que la abandonó. Sólo con olvidar las obligaciones que le recuerdan cada mueble, cada ventana, cada lámpara, devuelve a éstos su paz sabática (sabbatische Frieden), y por unos minutos se halla tan en concordia con las moradas, habitaciones y pasillos de la casa como a lo largo de toda la vida le afirma la mentira. Acaso no de otro modo aparezca e! mundo casi sin cambio a la perpetua luz de su festividad, cuando no esté más bajo la ley del trabajo y en el regreso al hogar las obligaciones le resulten tan fáciles como el juego en las vacaciones. [MM: 126-127] (MM; 111).

En esta frase la relación del niño con las cosas está tematizada a modo de una experiencia revitalizante de la novedad de lo cotidiano; y tal es el modo en que consideramos que podría pensarse la situación de conocimiento; es decir, como experiencia ampliada del objeto por parte de un sujeto receptivo. En medida en que consideramos al conocimiento como un modo de experiencia en el que nuestras capacidades perceptivas son modificadas, y en el que nuestra sensibilidad es asumida como elemento esencial, este fragmento puede valernos como ejemplo de esa relación cognoscitiva y experiencial en el que los hombres son liberados del "tedio de la prisión subjetiva del conocimiento" [ND 84] (DN; 83).

El conocimiento en Adorno está pensado como experiencia liberada del cierre que producen las categorías cognitivas; conocer implica salir de la cárcel de la inmanencia del sujeto y transformar la mirada sobre el mundo cotidiano, es el estado "sabático" del que no está aprisionado por las obligaciones de tener que clasificar e identificar. Un conocimiento atravesado "por la luz de su festividad" en el que los objetos se nos presenten con otra faz, y ante el cual la novedad no es solamente la irrupción de lo desprovisto de conceptos (de esa X misteriosa nietzscheana, de un noúmeno como límite de la racionalidad en el sentido kantiano), sino que la novedad radicaría en una experiencia cognitiva ampliada como "mirada sabática" y asombrada sobre la cosa, como una destitución del sentido común reificado, un acceso a las capas que ese objeto posee y una nueva 
posición del sujeto ante la objetividad. El sujeto sería así rescatado de su celda ideológica en la medida en que el debilitamiento de su capacidad experiencial pudiera ser reconvertido, y sus sentidos ampliados para percibir de otro modo su entorno cotidiano. Esa nueva relación entre sujeto y objeto, dada en términos de una "paz sabática", sin violencia identificadora, es lo que le permitiría al sujeto ser liberado de las represiones que ha debido infringirse civilizatoriamente. El sujeto empobrecido, frío y manipulador daría lugar así a un nuevo tipo de subjetividad capacitada para entablar relaciones más diferenciadas y humanas.

\section{Algunas consideraciones finales}

Debido a los múltiples planos recorridos conviene ahora hacer un alto y retomar lo fundamental de las ideas planteadas. Los diferentes niveles analizados de crítica al sujeto -como historia natural y como metacrítica- tuvieron en común el intento de mostrar de qué modo esa subjetividad está constituida en relación con una objetividad que es suprimida, ya sea como naturaleza interna o bien como alteridad en cuanto objeto no codificado por las categorías del sujeto. Para Adorno los mecanismos que guiaron la constitución del sujeto fueron la autoconservación sobre el entorno natural y el ejercicio de la identificación en su comunicación con el mundo. En estos análisis, el sujeto se nos presentó como una evidencia ideológicamente construida que no reconoce estar atravesado por mecanismos represivos y por instancias objetivas, que son tanto heterogéneas como internas a él. Un sujeto racional que exige ser liberado mediante una ampliación de sus capacidades experienciales.

Pero vimos cómo con este ejercicio de metacrítica Adorno pretendió mostrarnos que en el plano del conocimiento también es posible llevar a cabo un proceso de desestructuración del sujeto ideológicamente autónomo. Adorno no impugna a la gnoseología en su totalidad apelando directamente a otro plano (sea la historia, la política, el arte, etc.), sino que revalorizó la esfera del conocimiento 
como esfera en la que se puede pensar ese la liberación de ese cierre ideológico. Concibió así al conocimiento como una forma de felicidad posible que puede dar la pista de un sujeto no aprisionado por la identidad, de un sujeto liberado de las cárceles del pensamiento identificante. Si, como afirma Adorno, "lo que la filosofía trascendental ensalza como subjetividad creadora (an der schöpferischen

Subjektivität) es el encierro del sujeto dentro de sí (Gefangenschaft des Subjekts), encubierta para el sujeto mismo" [SW: 750] (Con: 151), entonces la tarea será buscar un modo de relación sujeto-objeto que permita romper esa cautividad. Es así que uno de los modos posibles de esa relación Adorno parece encontrarlo en la posibilidad de un conocimiento anclado en una forma ampliada de experiencia, en la que el sujeto y el objeto consumen un encuentro sin jerarquías y sin imperialismos, es decir un conocimiento concebido en términos no subjetivistas en ese estado de "paz sabático".

Es totalmente correcto entonces decir que Adorno se mueve con un esquema sujeto-objeto, pero lo hace en términos materialistas y no subjetivistas. Esto es, lo hace tratando de develar las relaciones sociales y las represiones que se esconden por detrás de esa estructura, abriendo esa relación en términos de una dialéctica negativa otorgando prioridad al objeto, pero no a un objeto ya dado como en el empirismo, sino a un objeto entendido como heterogeneidad, y configurado mediante significados y sentidos históricos sedimentados. La apuesta adorniana consiste en criticar a la tradición desde sus propios términos, no se aparta del esquema del idealismo, pero pone ese esquema en sus propias contradicciones; por eso su crítica materialista es cabalmente inmanente. Esto lo vimos con el análisis de la "infraestructura" de la identidad que manifiesta la racionalidad del intercambio mercantil, pero que a la vez sólo puede valer como principio configurador del pensamiento en las prácticas de su uso.

Surge, ante esto, la pregunta de si una crítica del idealismo llevada de forma inmanente puede ser materialista todo el tiempo, o si ese momento materialista sólo viene después de que el idealismo haya sido abandonado por completo (Jarvis; 1999: 120-125). Esa es una pregunta que atañe al corazón 
mismo de lo que consideramos como crítica inmanente. Lo que hace Adorno al respecto es interrogar al idealismo con motivos materialistas, por ejemplo: a la dualidad pensamiento-realidad la interpela con la relación naturaleza-historia, al carácter fundante del pensamiento lo interpela con la reposición de las represiones somáticas previas al acto intelectual, a la autonomía de lo gnoseológico la decanta en una crítica de lo social. La crítica es materialista, pero su planteo es aún idealista, ya que se pretende demostrar que un marco idealista (la relación gnoseológica de sujeto-objeto) interrogado materialistamente hará evidente la necesidad de su rebasamiento. En definitiva, al reactualizar el planteo en términos sujeto-objeto lo que Adorno pretende es destruir las jerarquías entre un sujeto dominador y un objeto creado como en el idealismo, pero también entre un sujeto pasivo y un objeto determinante como en el empirismo. Por lo tanto, su tesis de la primacía de la objetividad no debe ser leída como una vuelta al empirismo, ya que la espontaneidad de la subjetividad debe ser mantenida, y el objeto al que Adorno alude no es el dato o la mera experiencia reglada, sino un objeto cualitativo que impacta en la sensibilidad y en las capacidades cognitivas del sujeto. Lo que está en el juego es la construcción de una "constelación" en la que pueda existir una comunicación entre ambos términos no signada por el principio de dominio.

En la crítica materialista adorniana está implícito un momento no-conceptual que no puede ser reducido por el pensamiento a riesgo de solidificarse o vaciarse de contenido. La "metacrítica de la teoría del conocimiento" tiene su especificidad en rescatar este momento no-conceptual en el concepto, y quitarle el "sueño dogmático" de su autarquía: "El desencantamiento (Entzaurung) del concepto es el antídoto de la filosofía. Impide su propagación: que se convierta para sí mismo en absoluto" [ND: 24] (DN; 21). Para Adorno la filosofía adquiere su telos en aprehender aquello que ella no impone, en penetrar en lo heterogéneo sin reducirlo a categorías y, de ese modo, encontrar su contenido en la diversidad y singularidad de los objetos. La crítica del pensamiento identificante es pensada entonces como una forma de "experiencia plena" no reducida por el principio de identidad o reducida a categorías exteriores. 
Debido esto la crítica debe descentrar al sujeto como fuente única de sentido a partir de la exigencia de la prioridad del objeto, del respeto a lo otro que el pensamiento no puede reducir. Adorno da cuenta de este momento en términos trascendentales, en la medida en que lo que interesa es describir el conocimiento, no sobre patrones cognitivos o sobre reglas para la dirección del entendimiento sino, describirlo como experiencia. Para esto intenta elucidar las condiciones de posibilidad de esa experiencia ampliada. Pero, y esto es lo más interesante de su idea de "primacía del objeto", esta exigencia de un sujeto que respete la singularidad del objeto significa también la posibilidad de un sujeto liberado de la ideología de su autonomía. La crítica entonces tiene sus consecuencias también para el sujeto cognoscente porque, si bien este nuevo sujeto descentrado pierde su soberanía sobre el objeto y su potestad de asignación omnipotente de sentido, lo que de esto resulta es la emergencia de un sujeto auto-consciente, capacitado para hacerse responsable de sus mediaciones externas, y enterado del origen no-subjetivo de sus determinaciones.

Más relevante aún es que este sujeto autoconsciente sería un sujeto con su potencial experiencial ampliado y cuya capacidad cognoscente se vería enriquecida. De ese modo adquiría una autonomía y una libertad para percibir lo que hasta el momento su caparazón conceptual le negaba. Esta nueva capacidad de experiencia es para Adorno sin dudas una experiencia somática, sensual y moral, no reducible a parámetros cognitivos: el sujeto que piensa debe ser un sujeto encarnado y, por lo tanto, capacitado para revalorizar sus experiencias (históricas, estéticas, intersubjetivas) como medio de conocimiento. En tanto que "en la cosa le aguarda el potencial de sus cualidades, que exige un sujeto cualitativo y no un residuo trascendental" [ND: 50] (DN: 51), la liberación del objeto de las cadenas de la identidad supone, y tiene como consecuencia, la liberación del sujeto de sí mismo. Sólo aquí podemos comenzar a pensar en una figura de la subjetividad que haga posible el cumplimiento del imperativo categórico que exige que Auschwitz no se repita. 


\section{ANTISEMITISMO Y MODERNIDAD}

En este tercer capítulo intentaremos ver cómo las premisas señaladas en los capítulos precedentes adquieren sentido como análisis de un fenómeno histórico a partir de la problematización del antisemitismo. La crítica al sujeto se convertirá aquí en crítica de la figura ideológica del antisemita, y nos permitirá ver con más detenimiento esa conciencia cosificada que actuó como condición de Auschwitz. Para llevar a cabo esto plantearemos la discusión en dos planos. Por un lado, discutiremos el problema del antisemita en el marco de una crítica al empobrecimiento de la experiencia según las premisas de la crítica al sujeto elaboradas anteriormente. Pero, por otro lado, abordaremos el análisis adorniano de las relaciones conceptuales del antisemitismo con la modernidad, ya sea indagando en el carácter homogeneizador de la modernidad como ethos que hizo posible la consumación del antisemitismo en Holocausto (I), y analizando la relación entre antisemitismo, modernidad y nazismo a partir del concepto de "rebelión de la naturaleza" (II). Esto nos permitirá ver qué tipo de correspondencia se establece entre este modo de pensar la modernidad y la relación con el pasado reciente en Adorno; para esto nos serviremos de una comparación con las posiciones que Habermas elaboró en el marco de lo que se conoció como Historikerstreit (III).

\section{Antisemitismo y el problema de la experiencia}

Pero antes de comenzar con el análisis del antisemitismo en términos de una crisis de la experiencia veamos muy someramente en qué términos Adorno diagnostica el contexto de transformaciones sociales en el que esto tiene lugar. Según Adorno la sociedad pos-liberal, o sociedad del "mundo administrado" (Verwaltete Welt), puede ser definida como un tipo de sociedad que suprime toda 
mediación en la relación individuo-sociedad y, a partir de la posibilidad de sustitución plena de todos sus elementos, establece relaciones de dominación inmediatas por medio de las cuales las estructuras económicas se reproducen unilateralmente en la conciencia de los individuos [SSI: 177-196] (ESI: 165-183). La sociedad del tardo-capitalismo es una sociedad compuesta de aparatos estatales y monopólicos, ante los cuales una individualidad frágil pierde todo resguardo, puesto que ya no hay más un orden de emergencia espiritual por sobre los mecanismos de reproducción material de la sociedad: cada esfera de la vida social se encuentra mercantilizada y funcionalizada en la conservación de la totalidad social [SSI 122-147] (ESI: 114-137). En estas sociedades la burocracia estatal y el poderío económico que definen todas las perspectivas sociales van estrangulando los restos de autonomía que aún conservaba la sociedad civil, que así ya deja de entenderse como superestructura. En la época de la industria en gran escala, el empresario independiente desaparece en la red de los grandes cartels monopólicos ${ }^{29}$. Lo importante es que con el pasaje de la sociedad liberal hacia la sociedad pos-liberal, el individuo autónomo de la modernidad pierde su base económica y el papel de la autoconservación cambia radicalmente de función: ya no se define como lucha por la supervivencia, sino como adaptación a las estructuras sociales [SSII: 440-447] (ESI: 412-427).

29 Estos análisis están inspirados en estudios que Friedrich Pollock realizó en los años 30' sobre el "capitalismo de estado". Pollock se refería con este concepto a un nuevo estadio en la economía, distinto del laisser-faire y del capitalismo imperialista y monopolista de fines del siglo XIX. Según Pollock, en este nuevo tipo de capitalismo la regulación de la vida económica mediante el mercado quedaba suspendida y en su remplazo aparecía la figura del estado que, podía ahora regular de forma planificada; de este modo, la lógica de la ganancia quedaba supeditada a la lógica del beneficio político pero sin por ello quedar denegada, por lo que las contradicciones pasaban a estar concentradas casi exclusivamente en la esfera de la conducción gubernamental. Pollock consideraba que debido a la anulación azarosa de las contradicciones del mercado este nuevo orden era relativamente estable y con posibilidades importantes de subsistencia, pero al precio de militarizar la economía en un estado de guerra permanente. Los estudios de Friedrich Pollock que aquí aludimos son básicamente dos artículos publicados en 1941 en el tercer número de la revista del Instituto, reabierta en EEUU y llamada Studies in Philosophy and Social Science. Los artículos en cuestión son "State Capitalism" y "Is National-Socialism a New Order?". Estos estudios ocasionaron una disputa al interior del Instituto por la caracterización del nazismo entre Franz Neumann y Otto Kirchheimer por un lado y Friedrich Pollock, Max Horkheimer y Theodor Adorno por el otro, disputa que definió buena parte de los reacomodamientos institucionales e intelectuales al interior de la Escuela de Frankfurt. Para un análisis de este debate véase Wiggershaus (2010: 352-368). La posición de Adorno con respecto a las ideas de Pollock es bastante discutida entre quienes afirman que la teoría social adorniana estaría enteramente apoyada en las tesis de Pollock (Honneth; 1993: 40-55) o entre quienes matizan y complejizan esa relación (Cook; 2005, 16-25). 
Este proceso de integración de la individualidad en las estructuras del "mundo administrado" tiene su complemento en una teoría de la regresión del individuo basada en la teoría freudiana del Yo. Adorno va a considerar que el principal problema en el nivel psicosocial radica en la pérdida de autoridad de la figura del padre debido a la carencia de autonomía económica en una sociedad hiper-administrada, lo que allana el camino de una socialización directa del niño en manos del poder administrativo. El niño antes podía formarse una conciencia moral a partir de la interiorización de normas y sanciones representada por la autoridad paternal, esto le permitía también controlar sus pulsiones y, de ese modo, protegerse de las imposiciones sociales externas en su comportamiento. Debido a la disolución de la autoridad social del padre, al niño le faltaría ahora el necesario contrapeso personal requerido para la interiorización de normas y prohibiciones que dan forma a la conciencia moral. El carácter del individuo en las sociedades de masas posliberales se forma entonces en un proceso de total heteronimia, que provoca una desestructuración del Super-yo y un proceso complementario de regresión narcisista del yo ${ }^{30}$ [SSI: 42-86] (ESI: 39-79).

30Este análisis psico-social de pérdida del yo estaban basados en los trabajos que había realizado Erich Fromm para los Estudios sobre Autoridad y Familia, investigación colectiva realizada en los primeros años del exilio norteamericano por el Instituto de Investigaciones Sociales dirigidas por el mismo Fromm y por Horkheimer. En esos estudios Fromm había diagnosticado que las sociedades del capitalismo monopólico ocasionaban sentimientos de impotencia masivos que determinaban transformaciones en el carácter de los individuos y en sus disposiciones sociales. Surgía así una nueva estructura pulsional materializada en la generalización del carácter masoquista, como adaptación de la estructura de los instintos a determinadas condiciones sociales que se puede ver en racionalizaciones encubiertas de insatisfacciones reales. El carácter sadomasoquista reaccionaba con sumisión ante los más fuertes y con desprecio ante los más débiles, y se encontraba en estrecha relación con las formas sociales autoritarias del capitalismo monopólico. Para un estudio de este debate ver Wiggershaus, (2010: 191-199). En esa misma investigación Horkheimer había diagnosticado elementos represivos y autoritarios en la familia burguesa en la tendencia a la identificación de los hijos con la autoridad de la figura paterna, en la tendencia al sacrificio y lla sumisión a las figuras potentes. Esto sucedía con mayor fuerza en las familias de los estratos sociales más bajos, donde justamente los nazis encontraron una adhesión más decidida. (Horkheimer, 2003: 130-132) Esta apreciación de la familia liberal será modificada en los años 40' por Horkheimer cuando comience a considerar los efectos benévolos en la formación del carácter de los individuo; En este momento considerará a la familia burguesa una instancia mediadora que amortiguaba la influencia de los aparatos de poder sobre el individuo y aseguraba un contexto de formación cultural para el yo en el ámbito privado (Horkheimer, 1986: 79-89 y 167-169) 
El Yo, cargado por las exigencias de un domino de sus pulsiones y de la necesidad de una autoconservación racional, regresa a un estado libidinal previo -fase anal- con el fin de huir de la experiencia de su impotencia social. Así, la libido disponible se dirige ya no hacia la propia persona, sino a las figuras que la sociedad ofrece como modelo, hacia la celebrity de la industria cultural o hacia el líder totalitario. Mediante mecanismos de proyección en estas instancias sustitutas los individuos se aseguran una superioridad sobre la situación que ya no están en condiciones psíquicas de controlar. Será esta etapa posliberal del capitalismo la que va a crear las condiciones necesarias para la regresión de psíquica a una fase infantil del narcisismo, en el que las capacidades intelectuales y morales del yo se verán debilitadas. Por lo tanto, el potencial pulsional de los individuos podrá, de este modo, ser directamente canalizado por el poder administrativo, sin que se desarrolle una dinámica pulsional conflictiva al interior del yo [SSII: 434-440] (ESI: 406-412).

Pero lo que a nosotros nos interesa no es tanto esta psicología del antisemitismo, que fue muy discutida y justamente criticada en su momento (Honneth; 1985: 72-94; J. Benjamin; 1977), sino más bien ver en qué medida el fenómeno del antisemitismo puede ser tematizado a partir de un análisis filosófico de la capacidad de tener experiencias. En este contexto de debilitamiento del yo será puesto en el marco de una crítica filosófica al sujeto de la identidad y la autoconservación que trabajamos hasta aquí. El antisemitismo Adorno lo entenderá como un fenómeno ligado a la psicología de las masas en los que hay un aflojamiento de los procesos de consumación del yo, pero que sólo se entiende en el marco de una crisis en la capacidad de tener experiencia como problema de la constitución de subjetividades. En el marco de la crítica al sujeto que estamos estudiando, el antisemita representará el paradigma de un sujeto con su sensibilidad cosificada y el punto final del desarrollo de ese proceso de debilitamiento de la individualidad ${ }^{31}$. Pero al mismo tiempo la subjetividad

31 Un análisis similar del fenómeno del antisemitismo y el fascismo lo encontramos en la obra de un colaborador cercano al Institut, al menos hasta 1939; en su El Miedo a la Libertad (1942) Erich Fromm realiza un análisis de la personalidad del antisemita en términos que pueden parecer similares a los de Adorno. Para Fromm el carácter autoritario que caracteriza al antisemita se inscribe también un proceso de declive de una individualidad autónoma acaecida en las 
antisemita será también la que nos abra a una compresión más profunda de la relación entre modernidad y barbarie.

Para abordar el problema del antisemitismo en el contexto de la crítica a la subjetividad tendremos que replantear el problema que en el capítulo anterior describimos como experiencia cosificada, pero ahora ya no en el plano del conocimiento, sino en el marco de las relaciones sociales. La estructura de una experiencia ampliada en estos términos intersubjetivos para Adorno es básicamente la misma: el sujeto de la identidad ve disminuido sus potenciales experienciales al no poder entablar una relación con una alteridad. Esta impermeabilización del sujeto ante la heterogeneidad del objeto, se repite en el antisemita como no-reconocimiento de una otredad y como asimilación patológica a sus propios esquemas.

Cuando indagamos en la constitución de toda experiencia vemos que ésta contiene la exigencia de un momento pasivo y de un momento activo. El momento pasivo se basa en la apertura de las estructuras perceptivas a la determinación de una objetividad ajena al sujeto. Esta pasividad de la experiencia nos previene del peligro de solipsismo y, a la vez, nos permite un enriquecimiento de nuestra subjetividad mediante su contacto con un objeto externo y rico en determinaciones

sociedades tardo-capitalistas, esto genera determinada estructura de carácter en sociedades totalitarias caracterizadas por una "presencia simultánea de tendencias impulsivas sádicas y sadomasoquistas". Fromm entiende el sadismo "como un impulso dirigido al ejercicio de un poder limitado sobre otra persona, y teñido de destructividad [...]; el masoquismo en cambio, como un impulso dirigido a la disolución del propio yo en un poder omnipresente, para participar así de su gloria. Tanto las tendencias masoquistas como las sádicas se deben a la incapacidad del individúo aislado de sostenerse por sí solo, así como a su necesidad de una relación simbiótica destinada a superar esta soledad" $(2011,316)$. Esta estructura simbiótica del carácter del antisemita que describe Fromm tiene semejanzas con la patología de la experiencia en el que son sobredimensionados los aspectos pasivos y activos del antisemita que vimos en Adorno. Sin embargo, el análisis de Fromm está llevado a cabo como un análisis caracteriológico en el que a partir de los conceptos de "carácter social" y "adaptación dinámica" describe tipos de caracteres reactivos en la época de disminución del yo autónomo. Este estudio describe el fascismo también como un proceso asentado en la misma estructura civilizatoria, pero apela a un instrumental con el que Adorno entabló una expresa polémica, es decir se inscribe en la línea de la psicología del carácter que impulsaron los "revisionistas" de Freud. Adorno hacía derivar su análisis del antisemitismo más de una relación de rebelión contra las opresiones en un núcleo biológico que de tipos caracteriológicos que se daban en un contexto histórico-social, y esto a su vez determinaba que su confianza con respecto a las potencialidades de espontaneidad fueran menores que las de Fromm. La crítica a revisionismo puede verse en "El Psicoanálisis revisado" (ESII, 19-39; SSII, 20-42), un análisis de la relación entre Fromm y Adorno en Wiggerhaus (2004, 341-344). 
propias. Por otro lado, la experiencia implica la posibilidad de estructurar en una narrativa ese material que ya viene mediado, de llenar ese espacio vacío que queda entre la pura percepción del fenómeno y nuestra representación del mismo; es por eso que la experiencia también implica una formación y una significación de lo dado. Tener experiencia entonces significa entablar una negociación entre las propias mediaciones y las mediaciones que el objeto ya contiene; y es en este juego de apertura y acción en el que se forja nuestro yo experiencial (Jay; 2009: 85-88).

Ahora bien, si este "yo" cierra sus puertas a la comunicación con toda heterogeneidad acaba por osificarse en una estructura automatizada; pero si, por el contrario, se da en una relación no mediada e incontrolada a su objeto acaba por diluirse en la pura inmediatez, se pierde en la indiferenciación de las sensaciones y liquida su autonomía. Por lo tanto, el sujeto no debe ni agotarse en un registrar datos o en buscar experiencias totales o místicas no mediadas interpretativamente, ni tampoco en construir la totalidad del mundo desde su interioridad. Sólo en la mediación entre la productividad del sujeto y la entrega abierta a lo que ofrecen los sentidos se constituye una experiencia enriquecida.

Será en este marco que podremos leer el análisis adorniano del antisemitismo como una patología de la experiencia: en el antisemitismo el juego entre el aspecto pasivo y el activo de la experiencia se encuentra suspendido; o mejor dicho, ambos aspectos se encuentran identificados en una quietud cosificada que se resuelve por la vía de una exteriorización de pulsiones destructivas. El aspecto activo se convierte en "proyección patológica" [DA: 201] (DI: 235) mientras que el pasivo en "esquematismo" (Schematismus) del pensamiento [DA: 103] (DI; 130).

1) Resolución del aspecto activo de la experiencia como "proyección patológica": este rasgo es asimilable a la estructura perceptiva del paranoico, quien no puede distinguir entre lo que es propio y ajeno en el material proyectado. Los impulsos propios del sujeto le son atribuidos al objeto; así un sujeto menguado y engañado inyecta sus impulsos destructivos en la figura de su víctima. El sujeto 
se pone en el centro del mundo, que así deviene en una excusa para su accionar: "el mundo queda reducido al conjunto, impotente y omnipotente a la vez, en todo lo que el sujeto proyecta (Projizierten) sobre él" [DA: 215] (DI: 233). Esto significa que el paranoico se ha detenido en el momento afirmativo del pensamiento, sin llevarlo hasta su negación mediante un acto de reflexión. Es alguien que se ha dejado seducir por la fuerza de la inmediatez, por "la brutalidad inherente de lo positivo" (der Brutalität, die dem Positiven innewohnt) [DA: 220] (DI; 238). Esa carencia de objeto lo lleva a que no pueda conducir su pensamiento al momento de negatividad y reflexión. Para Adorno este mecanismo proyectivo significa la exacerbación del pensamiento identificante que ejerce violencia sobre la cosa experimenta. Es este el modo en que el antisemita construye su experiencia como un desborde patológico de su aspecto activo, como una forma de pensamiento frenético que no se deja determinar por el objeto. Precisamente, en el antisemita "el esquema social de la percepción quizás esté configurado de tal modo que no les permite ver a los judíos como hombres", lo que explicaría de algún modo la "tan oída afirmación de que los salvajes, los negros o los japoneses parecen animales, casi monos, contiene ya la clave del pogrom" [MM: 118] (MM: 104).

2) Resolución del aspecto pasivo de la experiencia como "esquematismo del pensamiento": para Adorno el proceso de racionalización técnica del mundo descripto por Weber termina por invadir esferas de la vida que se habían mantenido marginadas, llegando a penetrar incluso el ámbito de la experiencia individual, que así adquiere un carácter esquemático como módulo mental automatizado [DA: 229] (DI, 244). Como vimos durante el "mundo administrado" el individuo se vuelve innecesario, representa un obstáculo para la producción, y su pensamiento reflexivo es remplazado por esquemas: el dinamismo interior del yo que sostenía la tensión entre conciencia moral, autoconservación e impulsos queda suplantado por una relación cuasi-automática entre la reacción de los sujetos y las disposiciones sociales. En este sentido se puede entender la enigmática frase: "no hay más antisemitas" [DA: 226] (DI; 243), debido a que el antisemitismo ya no es el producto de la creencia basada en las experiencias de la vida, sino sólo un "ticket" que puede ser intercambiado por otros, o bien una 
opción más dentro del ticket fascista: "si la masas aceptan el Ticket reaccionario, que contiene el punto contra los judíos, obedecen a mecanismos sociales en los que las experiencias (Erfahrungen) de los individuos singulares con judíos no desempeñan ningún papel" (Op. Cit.). Por ende, sería el automatismo de identificar determinados rasgos en determinadas categorías lo que constituye la estructura del antisemitismo, y no un conjunto de inclinaciones personales o de actos conscientes.

Lo interesante de estas reflexiones es que tanto el esquematismo como la proyección nos indican que, por ejemplo, el progrom, como acto de violencia prototípica contra un grupo social, puede ser entendido como el producto de una forma patológica de experimentar relacionada con aspectos reificados de la subjetividad. El antisemita sería entonces el prototipo social de la subjetividad encerrada en sí misma que, como vimos, encuentra su origen "genealógico" en el dominio sobre la naturaleza y su modelo conceptual en la teoría del conocimiento moderno. Para esclarecer un poco más de qué se trata este modo de experiencia que marca la fisonomía vacía y automática del antisemita, vale un comentario realizado por Jean Paul Sartre en su ensayo sobre el antisemitismo, allí se nos ofrece el relato de una situación un tanto cómica que funciona muy bien para ilustrar lo que venimos argumentando:

Uno de mis amigos solía contarme de un viejo primo llamado Jules que iba mucho a cenar a casa de su familia y del que se comentaba [...]:"Jules no puede soportar a los ingleses". Mi amigo no recuerda que nunca se dijera nada más sobre su primo Jules. Pero eso bastaba. Había un contrato tácito entre Jules y su familia, delante de él se evitaba ostensiblemente mencionar a los ingleses y dicha precaución le otorgaba a ojos de sus parientes un viso de existencia a la vez que les procuraba a ellas la agradable sensación de estar participando en una ceremonia sagrada. $Y$ de pronto [...] alguien lanzaba [...] una alusión a Gran Bretaña y sus dominios. Entonces el primo Jules fingía ser presea de una inmensa cólera, por un instante se sentía "existir", y todos contentos. (1948: 57-58).

El odio del primo Jules hacia los ingleses no está necesariamente basado en un contacto concreto y personal con un inglés, pero funciona de modo 
automático como un registro de autenticidad de la propia persona, como la delimitación de una personalidad que se define en ese aspecto por etiquetas fijas no sujetas a reflexión: en este caso, el odio a los ingleses; se trata de un ejercicio irreflexivo de afirmación del yo. Este modelo de afirmación personal le sirve a Sartre para caracterizar al antisemitismo en términos de una estructura de la personalidad que se impermeabiliza ante la argumentación y ante la experiencia concreta. Tanto para Sartre como para Adorno el antisemita es alguien con una experiencia deformada, sin capacidad de introspección, y que sólo actúa como un carácter que encuentra su criterio en la externalidad. El antisemita no es nada "sino el miedo que suscita en los otros" (Ibídem.: 23) y, como reflejo de sus acciones reificadas, su conciencia es sólo un mecanismo automático.

En definitiva, para el primo Jules como para el antisemita no hay semitas ni hay ingleses, sino solamente un yo que actúa como mecanismo de repetición. El antisemitismo en este análisis es producto de una crisis de la experiencia que se caracteriza por una pérdida de su objeto y por una consiguiente solidificación de las estructuras perceptivas. Ya sea como "proyección patológica" o como "esquematismo", lo que se ausenta es la experiencia propia de la otredad, una carencia de objeto en la medida en que el sujeto lo proyecta desde sus estructuras, o bien lo asume como ítem del esquema que ya viene prefigurado. Se trata del mismo esquema de sujeto sin objeto que vimos Adorno criticaba como modelo de la filosofía del conocimiento moderna, y que aquí tiene lugar como imposibilidad de reconocer singularidad en el otro. El antisemitismo es una modulación deformada de los componentes activos y pasivos de la experiencia que se han cosificado por haber perdido el objeto que era condición de posibilidad de su autorreflexión y de la constitución de una "experiencia plena". El antisemita no puede ser convencido, no pueden alegarse argumentos racionales para que deponga su creencia, porque en el antisemitismo "no se refuta a ningún adversario, no se justifica racionalmente ninguna tesis. El proceso lógico consiste meramente en la identificación, o más bien en el encasillamiento" (ES II; 43) [SS II]. 
La capacidad de modificar los mecanismos perceptivos necesita de un sustrato objetivo que no puede darse a voluntad del sujeto, sino que debe ser algo que se de por fuera de las estructuras perceptivas y de los esquemas mentales $y$, que posibilite la apertura de la experiencia y la autorreflexión. En definitiva, no se trata de contra-argumentar al antisemita, de resolver el problema ideológico en el plano de la acción comunicativa digamos, sino que es necesario "reconstituir la capacidad de tener experiencias" (ES II, 286) [SSII: 282]. Por ende, el antisemitismo es una ideología que se asienta en una pérdida del objeto y que posibilita que el esquema ideológico sea una simple confirmación de sí mismo que actúa como "ideología de la ideología". Es una ideología formal puesto que no depende de un contenido o de un adoctrinamiento teórico sino de una práctica, de un modo particular de experimentar. Pero ideología formal también en la medida en que se trata de un esquema de acción que no considera aquello sobre lo que se aplica o, como lo analizamos en la metacrítica, se trata de una esquema subjetivo desprovisto de un objeto no-idéntico. Para Adorno el antisemitismo no necesita al semita ni referencia empírica alguna, puesto que su subjetividad se construye sobre el modelo de un sujeto encerrado en su propia determinación.

Vale una aclaración al respecto. Esta pérdida del objeto en la ideología antisemita no implica que dicha ideología carezca de funcionalidad, ya que el prejuicio posee una función realmente importante en la estructura psicológica del antisemita. Este funcionalidad se nos hace visible cuando nos hacemos la siguiente pregunta: "¿qué bien aporta a la adaptación real de personas por lo demás 'prudentes' el suscribir ideas que no tienen base en la realidad y que asociamos de ordinario con una inadaptación? (ES II; 287) [SSII: 283]. Adorno contesta a esto: el antisemitismo es una estructura cognoscitiva que permite ordenar una realidad que se ha tornado más compleja y distante de la vida cotidiana, a la vez que provee una fuente para insertarse en estructuras sociales que aparecen ante el sujeto como todopoderosas e inaccesibles. Es decir, el prejuicio actúa como marco gnoseológico para conocer el mundo, a la vez que constituye un patrón pragmático para insertarse en las tendencias objetivas de la sociedad. La ideología del antisemitismo asegura así un modo práctico de 
comportarse ante la realidad mediante un patrón cognitivo firme y una regla para las acciones.

Pero esta "objetividad" funcional de la ideología no le va a ahorrar al antisemita una serie de tensiones en su economía psicológica, tensiones que deberá saldar constantemente: si bien el antisemita ha resuelto la tensión entre la experiencia del objeto y el estereotipo en favor del estereotipo y en desmedro de la experiencia del objeto, esa realidad que ha suprimido, y en cuyo lugar ha colocado una modulación de proyección-esquematismo, no puede ser anulada completamente puesto que, quiera o no, una y otra vez vuelve a hacerse presente. Así, el antisemita tiene que resolver el constante conflicto entre su afirmación y la experiencia del mundo mediante ciertos "estratagemas" que devienen en construcciones fantasiosas y delirantes. Esto es posible gracias a un desplazamiento en el que no sólo lleva lo que es del sujeto al objeto - como proyección patológica-, sino que también intercambia las cualidades del estereotipo y la experiencia: el estereotipo es tomado como lo verdadero, lo lleno de vida, lo experimentado, mientras que la experiencia es tomada como lo falso, como portadora de una obligación abstracta, como el estereotipo (ES II; 300) [SSII: 301].

Sin embargo, para sostener esta "mentira" el antisemita debe llevar a cabo un perpetuo simulacro de juicio contra los judíos, puesto que debe dar la apariencia de la legalidad que él sabe estar violando y restituir la ley moral aunque más no sea como "caricatura" (ES II; 308) [SSII: 310]. La estrategia ideológica del antisemita parece convertirse en una actividad perpetua de desplazar significados para que el estereotipo pueda mantenerse. Es por esto que Adorno habla de una suerte de "mala conciencia" ocasionada al negar constantemente la realidad evitando la "mirada" de la víctima:

el crimen (Mord) es entonces el intento continuo de poner en razón la locura de esa falsa percepción (Wamehmung) mediante una locura mayor: lo que no se ha visto como hombre, a pesar de que lo es, es convertido en cosa (Ding) para que no pueda ya contradecir mediante ningún movimiento la maníaca visión (manischen Blick). [118-119] (MM; 104). 
Ese esfuerzo constante por "poner en razón la trastorno de esa falsa percepción" relativiza en alguna medida el aspecto maquinal de la ideología antisemita, puesto que sostener el esquema de proyección requiere un arduo trabajo para neutralizar la resistencia de la realidad; un esfuerzo de supresión de la objetividad y de represión de la naturaleza interna que ocasiona malestares y angustias sociales. El antisemita es por esto un sujeto consecuente en la medida en que se estructura sobre el esfuerzo constante por consumar una represión exigida en términos sociales. El antisemitismo como esquema, como ticket y como dispositivo social le ofrece la ventaja al individuo de llevar con el menor costo posible ese trabajo de represión. La ideología del sujeto concebida en estos términos consiste en la supresión de la posibilidad de autoconciencia mediante el trabajo de automatizar esas reacciones. Esta automatización consiste en evitar la "visión de la mirada" mediante la invención de mecanismos con los cuales el individuo pueda identificarse y suprimir la aparición del objeto de experiencia.

Por supuesto que esto plantea el significado de lo qué cosa constituiría una experiencia ampliada. Básicamente Adorno no piensa la experiencia como una suerte de anulación del sujeto en una experiencia absoluta no conceptualizable, de carácter místico, no lingüística. La experiencia tampoco consistiría en una amoldamiento de los datos de los sentidos a las categorías del entendimiento, ni la reducción positivista de la experiencia al registro de lo observable. Como vimos en el capítulo II, se trataría de mantener el momento subjetivo sin realizar violencia con el objeto, incluso es el objeto el que debe tener una preminencia en el encuentro con el sujeto llevándola a un proceso de desestructuramiento que de ningún modo implique una anulación de ninguno de los dos términos. Martin Jay define este esquema del siguiente modo:

Pese a que la experiencia se comprende de términos subjetivos, solo llega al encuentro con la otredad, luego del cual el yo ya no continúa siendo él mismo. Para mantenerse intacta dicha experiencia debe tratar al otro de una forma no dominante, no inclusiva ni homogeneizante, como si fuera un nombre propio referido únicamente a sí mismo y no en cuanto símbolo de otra cosa. (Jay, 2009: 402) 
Sin esa otredad no es posible experiencia moral alguna ni un yo autónomo. En Adorno hay un concepto normativo de experiencia que exige que el individuo deba perder su frialdad y su solidez aceptando la singularidad de un otro, que deba relativizar sus propios esquemas de comportamiento y su propia determinación en un encuentro con una alteridad. Sólo en el encuentro con lo distinto el sujeto puede salir de sus propias determinaciones y entablar relaciones reflexivas consigo mismo ${ }^{32}$. Ahora bien, este análisis de la crisis de la experiencia

32Conviene hacer ahora una observación sobre esta relación entre experiencia y subjetividad. Como vimos en el capítulo II y en lo que va de este capítulo la experiencia debe proporcionar al sujeto la posibilidad del encuentro con algo no idéntico a él mismo de modo tal que sus estructuras se dinamicen y pierda su carácter cosificado. Es en la obra de arte moderno donde para Adorno eso se produce de una forma más nítida; ya que allí se da un tipo de experiencia genuina que conviene detallar brevemente para hacernos una idea de esta noción normativa de experiencia que Adorno formula. En el arte el espectador llega a un encuentro mimético y sensorial con un material que no puede ser reducido a la simple expresión del artista. La cualidad enigmática del objeto artístico tampoco puede ser asimilada completamente por la intencionalidad del espectador. En el arte el sujeto y la obra llegan a un encuentro en el que es necesario reconstruir una comunicación en términos pacíficos y no homogeneizadores, como si fuese algo referido a sí mismo y no símbolo de otra cosa. En dicho encuentro el yo deja de ser el mismo, ya que la obra se desprende de las intenciones o las vivencias del artista y logra consumar un estremecimiento o temblor en el destinatario. En la experiencia estética se da tanto una liquidación del ego como un protesta contra la falta de ego, puesto que para que exista tal experiencia sigue siendo necesario una subjetividad. El arte como objetividad que no se deja reducir a los patrones comunicativos cotidianos tiene la capacidad de desestructurar lo cosificado del sujeto, pero sin pretender abolirlo puesto que lo necesita. Esta experiencia se da "en el instante en el que el receptor se olvida de sí mismo y desaparece en la obra: al instante del estremecimiento. El receptor pierde el suelo bajo sus pies; la posibilidad del la verdad que se encarna en la imagen estética se le hace presente. Esa inmediatez en la relación con las obras es función de la mediación, de la experiencia penetrante y amplia; ésta se condensa en el instante y para eso necesita toda la conciencia, no estímulos ni reacciones puntuales. La experiencia del arte es más que una vivencia subjetiva: es la irrupción de la subjetividad en la conciencia subjetiva" (TE: 322-323)

Este encuentro que violenta las estructuras del sujeto en una relación no instrumental con la objetividad de la obra Menke lo define como "negatividad estética". En el arte se produce una relativización de todos los sentidos subjetivamente asignados en otras esferas mediante una sensibilidad ampliada: "Si, en el dominio no estético el placer arraiga en un proceso de identificación o reconocimiento automático, en el domino del artes se basa en la negación estética de este mecanismo" (Menke, 1997: 34). Entonces si el sujeto está construido sobre la identidad, la esfera estética tiene la potencia para poner entre paréntesis ese mecanismo que estructura toda subjetividad. Pero en virtud de su autonomía esta capacidad del arte está limitado a la esfera de la apariencia estética y no puede ser extrapolada como modelo o pretender un carácter jerárquico con respecto las experiencias en otras esferas. Sin embargo esto, la experiencia estética puede poner entredicho la pretensión omniabarcante de la razón identificadora y todo sentido total construido sobre ella. Este concepto de "negatividad estética" implica una doble determinación del arte moderno: "como un discurso autónomo entre otros y, al mismo tiempo, como subversión soberana de la razón de todos los discursos" (ibídem: 17). Para Menke el arte es la instancia que pone en entredicho el carácter totalizador del sujeto de la identidad, lo desmiente en su pretensión de ser soberano y relativiza sus estructuras, sólo que el arte no es como dice Jay una "prefiguración de una experiencia genuina" (Jay, 2009: 402), sino que es realmente una experiencia genuina, pero autónoma en su esfera que no puede garantizar experiencias morales o cognitivas fuera de ella, sin embargo puede hacernos ver que la validez de la racionalidad identificadora es limitada, así como es limitado el sujeto que se estructura según esta racionalidad . 
que nos ha dado ciertos elementos para entender las estratagemas de identificación y reconocimiento de la mirada racista, ahora nos conduce a preguntarnos por las condiciones de posibilidad culturales que hicieron posible tal estado de cosas, y por el sustrato histórico-epocal en el que esta ideología asumió todo su potencial destructivo. Este sustrato histórico exige la elaboración de una teoría que:

ni enumeraría una diversidad de 'factores ' ni destacaría uno específico como "la" causa, sino que más bien desarrollaría un marco unificado dentro del cual están vinculados de forma consistente todos los "elementos". Ello implicaría nada menos que una teoría de la sociedad moderna en su conjunto. (ES II: 273) [SSII: 274]

Adorno con el análisis del antisemitismo como una análisis del declive de la capacidad de tener experiencias continua en el marco de una crítica de la conciencia identificante. El sujeto, al subsumir sus experiencias en un esquema que no permite ser mediado por contacto intersubjetivo alguno, identifica toda posible relación con un otro y la subsume bajo un principio común, imitando de ese modo la mirada patológica del paranoico. Pero, como expresa la cita anterior, este análisis estaría incompleto si no abordara el ethos en el que esto tiene lugar, si no explicara el antisemitismo en un contexto más amplio en el que tienen lugar esas transformaciones de la subjetividad.

\section{Modernidad y homogeneización}

Ahora bien, una vez analizado el problema de la experiencia veamos las condiciones culturales que hicieron eso posible. En esta parte del capítulo discutiremos las reflexiones que realiza Adorno sobre el antisemitismo en el marco de una crítica a la modernidad. Esa forma de presentar el problema no está exenta de dificultades, ya que implica insertar la discusión de un fenómeno histórico y social en los términos de una filosofía de la historia; sin embargo, creemos que, procediendo de esta manera, ciertas continuidades podrán ser mejor apreciadas 
que si se procediera solamente términos historiográficos o sociológicos. Esto no implica alentar a discutir estos problemas únicamente por fuera del marco de las ciencias sociales, sino que implica apreciar los aportes de la filosofía para comprender la historia y sacar a luz sus aspectos problemáticos y sus relaciones conceptuales no siempre visibles.

En Dialéctica de la llustración, Adorno conceptualiza el antisemitismo en un contexto epocal en el que los supuestos que habían regido la historia cultural y política de Occidente comienzan a definirse por su lado regresivo. Este texto, publicado por primera vez en el año 1944, intenta mostrar cómo es que la modernidad, que había vuelto pensables los anhelos de libertad, de emancipación, la consolidación del individuo autónomo y racional, así como las aspiraciones a un estado fraterno entre los hombres, comenzó a desarrollar un proceso de constante disolución. El patrón de regresión que guiará este proceso será, en el marco de la filosofía adorniana, la paulatina entronización de la identidad en cada uno de los ámbitos de la existencia, en el que la formalización de lo distinto forjará un mundo desespiritualizado pero homogéneo durante la modernidad avanzada. En este apartado analizaremos este proceso como formalización de la moral moderna según el principio de homogeneización.

Con el paso de la sociedad liberal a la sociedad pos-liberal se verán trastocados los conceptos político-morales que funcionaban como estructura ideológica. En "Libertad. Para una metacrítica de la razón práctica” de Dialéctica Negativa y en algunos fragmentos de Minima Moralia, Adorno procede a una crítica del carácter problemático de la moral moderna, paradigmáticamente ejemplificada en la ética kantiana. Según Adorno, la modernidad liberal había fundamentado el principio de tolerancia sobre el argumento de que todos los hombres eran iguales ante ley, que funcionaba tanto como una afirmación de igualdad natural y, a la vez, como ideal regulativo. En ambos casos se intentaba asegurar la convivencia pacífica en un estado donde todos los hombres debían deponer sus parcialidades valorativas: la moral era una cuestión de razón y no de 
pasión, ya que la deposición de todas las cargas afectivas y de los intereses subjetivos aseguraría una argumentación moral objetiva y universalmente válida.

Este principio de convivencia basado en la idea de tolerancia y de igualdad de todos los hombres ya había sido denunciado en su carácter formal por el Marx de La Cuestión Judía, sin embargo, lo que dejarán ver los análisis de Adorno, será el carácter aporético y destructivo de esta formalización de la moralidad, cuando tales principios sean encarnados en el desenvolvimiento histórico y en la red concreta de relaciones humanas: en ese marco se hará evidente que esos postulados formales serán intrínsecamente capaces de fundamentar tanto una norma de convivencia pacífica como una norma de destrucción recíproca [ND: 143] (DA: 140). Es esta la aporía de la moral moderna que el problema del antisemitismo pone en el centro de la discusión.

Es decir, en esta neutralización de los apasionamientos en la discusión moral, que debía garantizar un orden de reciprocidad, estaba escondida la posibilidad de reificación de una subjetividad como típica "frialdad burguesa" (bürgeliche Kälte) [MM: 82] (MM: 72). El sujeto relegaba sus impulsos para fundar una orden de reciprocidades libre de intenciones pero, a cambio de eso, le era devuelto un mundo desprovisto de implicaciones afectivas que pudieran actuar como resguardo ético ante la barbarie. Es en este contexto que la tolerancia y la igualdad, a causa de su formalización, dejarán librado el terreno a la extensión del poder $y$ al resentimiento frente a lo diferente. Ese principio formal de igualdad quiso ser mantenido como principio ideal de convivencia, pero las tendencias de la sociedad pronto lo iban a convertir en su contrario [ND: 235] (DN: 240). Es así, que el principio de igualdad de los hombres acabaría considerando las diferencias como estigmas sociales que debían ser suprimidas: incluso "la diferencia racial es absolutizada (zum absoluten erhoben), para que pueda ser completamente eliminada, lo que sucedería cuando no quedase nada diferente" y de allí al campo de concentración que iguala a todos los hombres con todos [...], y convierte a los prisioneros en sus vigilantes, y a los asesinados en asesinos" [MM: 116] (MM: 102). La moral, que había pretendido consolidar un estado en el que los conflictos 
fueran resueltos bajo el abrigo de una razón desprovista de pasiones, acabó en la destrucción más desapasionada y burocrática posible. Adorno advierte que, al desarrollar el principio formal que la moral contenía en su seno, ésta se convierte en relativismo que deja la puerta abierta a la barbarie. Esta dialéctica la describe Adorno cuando, refiriéndose a Kant, dice:

La doctrina de la razón pura práctica dispone la retraducción (Rückübersetzung) de la espontaneidad en contemplación, que se consumó en la historia posterior de la burguesía y se culminó en la apatía política, en lo más político de todo (einem höchst Politischen) [ND: 235] (DN: 258)

Para Adorno la dialéctica de la moral que describimos estuvo acompañada por un proceso de burocratización y concentración de la vida política y económica de la sociedad liberal. Sin embargo, al igual que la dialéctica de la moral, la sociedad administrada y totalitaria no es más que una consecuencia de esa misma sociedad liberal burguesa a la que puso fin. El principio de activación dialéctico estuvo regido por el carácter formal de aquella sociedad, en tanto se estructuraba mediante el principio abstracto del cambio de equivalentes en la relación mercantil. Este principio del intercambio mercantil constituía la argamasa que garantizaba la realidad de lo social como algo más que la simple multiplicación de individualidades dispersas [SS I; 9-20] (ESI: 9-19). La sociedad de la libre empresa había estado asentada en una abstracción objetiva y constitutiva, que ignoraba el carácter cualitativo de las cosas y que, mediante el valor de cambio como equivalencia formal entre elementos distintos, producía un estado de progresiva homogeneización de lo producido, del productor y de las formas de producción, según el célebre análisis del fetichismo de la mercancía de Marx. Lo novedoso, según Adorno, de la modernidad tardía o del capitalismo pos-liberal, será que este proceso de formalización se inmiscuirá también en el conjunto de las relaciones entre los hombres y sus producciones espirituales.

Esto, por supuesto, no constituye una auténtica teoría del fascismo, ni del antisemitismo, sino que intenta dar cuenta de las estructuras conceptuales y sociales que hicieron posible a ambos como armazón política y como modo de 
configuración de subjetividades. Lo que ha tenido lugar entonces para Adorno fue un proceso de homogeneización total, como perfecta consecuencia del intercambio mercantil y como de neutralización de las emociones en el plano moral. Proceso que expresa el avance del principio de homogeneización como historia íntima de la civilización, en el que tanto la sociedad como la moral llevaron a cabo un proceso de extirpación violenta de las particularidades. Entonces, existiría para Adorno una continuidad entre este proceso moderno de formalización e igualación, y el proceso de destrucción anónimo de las vidas humanas llevado a cabo en los campos de concentración. Tanto Auschwitz como el totalitarismo y el antisemitismo son resultado de la entronización de la identidad en lo social y de la formalización moderna de la moral. Es en este marco que Adorno entiende al genocidio como:

la integración absoluta que se prepara en todas partes donde los hombres son nivelados (gleichgemacht werden) [...] hasta que se los extermina literalmente como desviaciones del concepto de su perfecta nulidad (vollkommenen Nichtigkeit). Auschwitz confirma el filosofema (Philosophem) de la identidad pura como muerte. [ND: 355] (DN: 362).

En algún punto los términos en los que Adorno elabora su análisis no son muy distintos en los que Arendt está pensando el fenómeno del antisemitismo. En su obra Los Orígenes del Totalitarismo Arendt analiza la relación entre la ilustración y la historia de la asimilación de los judíos. La integración a las sociedades europeas para los judíos ilustrados (Mendelsohnn, Herder, Lessing) consistía en la formación (Bildung) de la personalidad y en la educación intelectual, que convertía a los judíos asimilados en hombres excepcionales en el marco de la sociedad burguesa; al mismo tiempo que se exigía de estos judíos el abandono de su pertenencia a la tradición judía en el ámbito de lo público. De este modo, se creaba una ambivalencia en la vida del judío: como intelectual excepcional y como judío renegado de su tradición veía su vida fragmentada. La ilustración entonces puso como condición para el reconocimiento de la integridad de los seres humanos la exigencia de un renunciamiento a la singularidad como judío, y abrió así un proceso de peligrosa homogenización social que se hizo 
patente en la imposibilidad de reconocer a los judíos y a otras culturas en su especificidad. Para Arendt esta idea de igualdad de la modernidad burguesa ilustrada fue progresiva en el plano político, mientas implicaba un reconocimiento formal y legal de la persona, pero se convirtió en dañina cuando fue llevada al plano social ya que allí conducía a la homogeneidad y a la discriminación de las tradiciones específicas:

"La igualdad de condición, aunque es ciertamente un requerimiento básico de la justicia, figura, sin embargo, entre los mayores y más inciertos riesgos de la humanidad moderna. Cuanto más iguales son las condiciones, menos explicaciones hay para las diferencias que existen en la gente; y así más desiguales se tornan los individuos y los grupos [...] Allí donde la igualdad se torna un hecho mundano en sí misma [...] hay un noventa y nueve por ciento de probabilidades de que será confundida con una cualidad innata de cada individuo que es 'normal' si es como todos los demás y 'anormal' si resulta ser diferente." (Arendt, 2009: 106).

Tal dialéctica de la igualdad conllevó que grupos sean reconocidos como iguales a condición de que sean discriminadas y reprimidos sus particularidades culturales. Pero el judío aun así seguía siendo considerado como un judío, como un distinto, lo que atrajo el resentimiento social contra ellos por su incompleta asimilación, a pesar de su condición de excepcionalidad intelectual. La ilustración para Arendt había creado las condiciones para una discriminación social del judío tal y como será practicada a lo largo del siglo XIX. Esta ambigüedad que debían experimentar los judíos -excepcionales como judíos y asimilados como ciudadanos- creó las condiciones para que "lo judío" fuera visto como un dato de nacimiento, como una condición existencial presente en todos los judíos, una enfermedad que sólo puede ser curada con soluciones drásticas.

El antisemitismo se convertiría así en una cuestión política con una gran potencialidad de movilización social como podrá verse con los movimientos y los partidos de agitación antisemitas (Ibídem.: 135-147); y será esta línea la que en siglo XX se convierta en un fenómeno de masas y exija soluciones radicales. Para Arendt entonces, la discriminación política sobre los judíos estuvo basada en el 
principio de igualdad del pensamiento liberal que, extrapolado al ámbito social, degeneró en una homogeneización hostil a toda diferencia. Con esto el judío dejaba de ser alguien vinculado a una tradición, a una religión y a una cultura para mantenerse como hombre asimilado; pero, al mismo tiempo, era considerado como intelectual excepcional debido a su condición de judío, por lo que esa judeidad comenzó a ser considerada como una condición ontológica o psicológica que debía ser integrada.

Vemos así que, si bien Arendt realiza un análisis en términos de un historia social del antisemitismo en algún punto las tesis concuerdan con el análisis adorniano, en la medida en que lo que está en la base del antisemitismo es el principio de homogeneización; principio que en Adorno es pensado como estructura conceptual tanto de la experiencia personal como de los procesos de modernización, y que en Arendt se establece como premisa teórica y tendencia cultural del liberalismo ilustrado. De algún modo, ambos autores describen procesos de configuración de un orden social homogéneo y de una progresiva abstracción que borra las particularidades sociales y culturales con un desenlace trágico. Pero con esta idea de la identidad y la homogeneización ilustrada como problema del antisemitismo, lo que estas tesis ponen de relieve es que el antisemitismo, tal y como se dio en las sociedades totalitarias, tiene una vinculación interna y profunda con el liberalismo y con la modernidad ilustrada, en la medida en que ambos se asientan sobre procesos de integración y homogeneización activados por la modernidad.

Esto nos lleva de forma directa a lo que aquí queremos plantear, es decir a la relación interna entre nazismo y modernidad, y al papel que desempeñó el judío en esa relación. Para esto veamos la tesis de "rebelión de la naturaleza" en el siguiente apartado.

\section{Rebelión de la naturaleza, modernidad y nazismo}


Ahora debemos ver qué tipo de relaciones conceptuales establece Adorno entre el antisemitismo y el nazismo, relaciones de tipo filosófica más que histórica. En Dialéctica de la llustración se desarrolla una tesis que servirá como hilo conductor de esta lectura filosófica de la modernidad, y es la idea de "dominio de la naturaleza". Con esta idea se afirma que la constitución de la racionalidad se produjo bajo los dictámenes de la autoconservación, debido a lo cual se hizo imperioso un domino de la naturaleza exterior a los fines de la reproducción social, y una represión de todo lo ligado a lo natural en el individuo (pulsiones, lo somático, la relevancia de lo sensorial, las tendencias al placer, etc.). Esta idea le ofrece a Adorno la posibilidad de realizar una lectura de las catástrofes de aquellos años en términos de un "retorno de la naturaleza reprimida". Esto nos permitirá conceptualizar la relación entre totalitarismo, antisemitismo y modernidad.

Ahora bien, para Adorno el antisemitismo es una forma de completar el proceso civilizatorio que él entiende como el ejercicio continuo de domino y represión de la naturaleza, es en ese marco que debe entenderse la importancia histórico-filosófica de este concepto. Proceso de dominación que genera altas cuotas de insatisfacción y malestar como expresa la siguiente cita:

Incluso como posibilidad, como idea, las masas deben reprimir siempre nuevamente el pensamiento de esa felicidad, y ellas lo niegan tan furiosamente cuanto más a tiempo está de cumplirse (an der Zeit ist). Dondequiera que este pensamiento, mediante una negación principio, aparezca como realizado, las masas deben reiterar la opresión, que apunta a su propio anhelo. Lo que se convierte en motivo para tal represión, por muy infeliz que se pueda ser: Ahasver o Mignon, extranjeros de la tierra prometida, belleza que recuerda el sexo, el animal marcado como repelente que evoca la promiscuidad: todo ello lleva al ansia de destrucción de los civilizados (die Zerstörungslust der Zivilisierten), que nunca pudieron concluir el doloroso proceso de la civilización. A quienes dominan obstinadamente a la naturaleza, esta atormentada les devuelve la imagen de la felicidad impotente (den Schein von ohnmächtigem Glück). [DA; 196] (DI: 217)

Debido a la rudeza y lo doloroso de las represiones que los hombres han debido infligirse a sí mismos para completar su subjetivización es que se han 
forjado diversas formas ideológicas para compensar el sufrimiento ocasionado y asegurar la reactualización de los lazos sociales. Pero lo que esta cita indica es que el dolor por la renuncia que los hombres debieron inflingirse aún perdura y que, además, aquella naturaleza que el hombre debía de sacrificar para constituirse como un sujeto vuelve otra vez en forma desbocada: la naturaleza "atormentada les devuelve la imagen de la felicidad impotente". Este retorno de la naturaleza reprimida es lo que en el análisis adorniano dará cuenta del significado histórico-filosófico del nazismo y su relación con la modernidad.

Como dijimos, en el excurso sobre Odiseo en Dialéctica de la llustración, Adorno tematiza la constitución del sujeto por sobre el dominio de la naturaleza basado en el olvido, la renuncia a lo afectivo y la astucia en el trato con las fuerzas míticas; del mismo modo, el individuo empírico consumó su yo en un proceso que va desde los estadios miméticos en la primera infancia hasta el yo operativo de la adultez como control de los impulsos en la construcción de una conciencia moral. Para esto, la sociedad debió crear ciertos mecanismos que anestesiaran el dolor y permitieran canalizar la libido que quedaba disponible con la liquidación de un super-yo moral, mecanismos como el antisemitismo o la industria cultural. Pero, para decirlo de alguna manera, "nada es gratis" puesto que, a pesar de todos los mecanismos de anestesia y de todas las estrategias de olvido y represión, esa naturaleza reprimida retorna, pero de modo deformado y con una carga de inusitada violencia. Así, en la visión de Adorno, es el estado totalitario el que asume la tarea histórica de canalizar este retorno de la naturaleza reprimida en beneficio de ese mismo dominio contra el cual se reveló:

La horda, cuyo nombre reaparece sin duda en la organización de las juventudes hitlerianas, no es una recaída en la antigua barbarie, sino el triunfo de la igualdad represiva, la evolución de la igualdad del derecho hacia la negación del derecho mediante la igualdad (Entfaltung der Gleichheit des Rechts zum Unrecht durch die Gleichen). [DA; 39] (DI: 68).

El totalitarismo, freudianamente interpretado, completaría un proceso de represión y renuncia de la naturaleza interior de los hombres a partir de la identificación del yo propio con el yo social, y en un contexto de homogeneización 
integral de la vida y el mundo de las personas. De este modo, el totalitarismo le ahorra al individuo el trabajo de pensar qué hacer con el impulso oprimido, que cada tanto se rebela sin mediación racional. Existiría entonces una relación estrecha entre nacionalsocialismo y naturaleza dominada, en la medida en que la naturaleza olvidada sea captada racionalmente para fines irracionales o canalizada en procesos de control social; por lo que, como manipulación de los deseos reprimidos por la civilización, el fascismo se convertiría en, según palabras de Horkheimer, una "síntesis satánica de razón y naturaleza" (Horkheimer, 1969: 132).

Esto otorga cierta inteligibilidad al apoyo que encontraron los nazis en las clases desplazadas de los procesos de modernización -campesinos, artesanos, empleados públicos, comerciantes, amas de casa, pequeños empresarios-, a la vez que pone de relieve el carácter simultáneamente moderno y arcaico del fenómeno totalitario: es decir, el fascismo por un lado apela a impulsos miméticos reprimidos, y por otro canaliza esos impulsos mediante una novedosa tecnología utilizada para el dominio político. Asume así el disciplinamiento de las pasiones e instintos que el sujeto moderno y el liberalismo habían forjado, pero ahora para reutilizaros con el objetivo de destruir ese mismo liberalismo y esa misma modernidad. Con esta tesis de la "rebelión de la naturaleza", vemos entonces que el fascismo tendría cierta función histórica en el marco de la civilización occidental. Para Adorno, el nazismo estaría en el concepto mismo de la modernidad liberal pero es, a su vez, aquello que amenaza con destruirla. El nazismo, según este análisis, expresión del carácter aporético del liberalismo ilustrado, es la consecuencia de la represión sobre los sentidos, las pasiones y lo somático sobre la cual se erigió la civilización.

Dada esta correspondencia entre nazismo y modernidad según la idea de "domino de la naturaleza", aún queda el trabajo de ubicar el lugar de la figura del judío en este marco. Para esto debemos responder a las siguientes preguntas: ¿cómo se inserta la representación del judío en la historia de la civilización?, o ¿en qué medida esa civilización así consumada necesita del judío?. Adorno muestra 
que en la representación que el antisemita se hace del judío existe una ambigüedad sustancial en tanto que "'[los judíos] son considerados por la civilización avanzada como atrasados y a la vez demasiados adelantados, como iguales y diferentes, astutos y tontos" [DA: 211] (DI: 230). De modo que, si para Adorno en la figura del judío se han solidificado las tensiones de la modernidad, la representación del antisemita será ambivalente y contradictoria como esas mismas tensiones: si la modernidad es la victoria sobre la naturaleza y la recaída deformada en ella, entonces el antisemita representa tanto a esa civilización victoriosa como a la naturaleza derrotada. Si el totalitarismo es el núcleo contradictorio de la modernidad, el judío puede ser el núcleo contradictorio del totalitarismo. Es así que el judío se presenta ante el antisemita como un objeto fundamentalmente ambiguo y que, por eso mismo, acepta definiciones paradójicas. Para fundamentar esta idea veamos las caracterizaciones variadas y contradictorias del judío en la mirada de Occidente que Adorno ofrece en sus "Elementos de Antisemitismo" en Dialéctica de la llustración:

1) Por un lado el judío siempre representó aquel que no podía ser asimilado y que por eso desmentía la universalidad homogeneizadora del orden liberal. El judío era lo no-occidental de Occidente, ese enemigo interior que debía ser continuamente vigilado. La figura del "parásito", con la que los nazis describían a los judíos, da cuentas de esta posición de amenaza interna a la cultura.

2) Pero cuando el judío quiso dejar de ser el distinto y emprendió la empresa de la asimilación, su situación no se modificó sustancialmente, ya que tuvo que endurecerse y reprimir sus particularidades como si se tratara de una "segunda circuncisión" cultural [DA; 193] (DI: 214). Por eso, en tanto el judío fue el representante de ese sujeto reprimido y autónomo, constituyó para el antisemita la imagen de las numerosas represiones que él tuvo que padecer: el judío recuerda los costos y los sufrimientos del proceso de subjetivación, del sacrificio de su naturaleza en la modernidad y del dolor que provoca toda asimilación.

3) Por otra parte, los judíos como excluidos de la esfera de la producción debieron localizarse en la esfera de la circulación como comerciantes o 
banqueros, de allí su estigma como usureros improductivos. Esto ayudó a las elites nacionales a encubrir la naturaleza acaparadora del sistema económico y del contrato laboral en el capitalismo, ya que toda la responsabilidad de la explotación se hacía visible sólo en la actividad comercial, monopolizada por el judío, que de ese modo fue víctima de una ilusión social, que "la responsabilidad de la esfera de la circulación por la explotación es una apariencia socialmente necesaria (gesellschaftlich notwendiger Schein)" [DA: 198] (DI: 219).

4) El judío era también la contrapartida bastarda de la filosofía política liberal, en la medida en que a él le fueron concedidas las libertades civiles pero no el poder político, del mismo modo que el liberalismo concedía públicamente la emancipación legal a todos los hombres, pero secretamente negaba la real emancipación social. En este proceso de emancipación civil el judío fue derivado a posiciones marginales pero necesarias al poder: como escriba, banquero, comerciante, abogado y acabó por convertirse en el representante de un liberalismo que, mediante libertades civiles, se ahorró de consumar una emancipación social. [DA; 199] (DI: 220).

5) El judío también representó la figura del intelectual potencialmente subversivo para las certezas que tenía la tradición. Podríamos decir que el judío es desde entonces el símbolo del intelectual moderno que, angustiado, amenaza el vínculo entre conocimiento y poder que trazó la modernidad; y es también el símbolo de la autoconciencia que puede poner en palabras el dolor que la civilización infringió a los hombres, es decir, es la imagen de la conciencia crítica siempre molesta para el poder político.

6) Por otro lado, y esto tendrá una especial relevancia, el judío es también la imagen de la mimesis incontrolada que debió ser reprimida para dar origen al trabajo productivo. El judío al estar exento del trabajo material en el que se cristalizaron las represiones del cuerpo representa a los ojos del antisemita la naturaleza que fue necesario sacrificar: los impulsos, los olores, el placer, la promiscuidad, lo salvaje, la fealdad, lo no mediado por las reglas de la cortesía y la 
civilización; en definitiva el judío es para el antisemita el desagradable y seductor refugio de los impulsos miméticos reprimidos por el sujeto.

Es esta última significación la que nos pone en el centro de la teoría de la rebelión de la naturaleza que se defiende en Dialéctica de la llustración: Fundamentalmente, Adorno entiende que es la energía psíquica creada por la represión de los impulsos lo que se libera en el antisemitismo. El antisemita busca satisfacer sus impulsos miméticos, entregándose a ellos, pero sin violentar abiertamente el principio de realidad o el principio del dominio, sino adaptándose a estos. Esto lo consigue imitando y destruyendo al judío, ya que "está permitido consentir al impulso (Trieb) prohibido si está fuera de duda que ello vale para su destrucción" [DA: 209] (DI: 230).

El antisemita identifica al judío con la naturaleza reprimida, con los rasgos miméticos que ha debido dejar de lado para adaptarse a la sociedad: "Ios judíos son acusados de practicar una magia prohibida, un ritual sangriento" (DA; 210). Todos los impulsos reprimidos por la civilización vuelven como proyección sobre el judío en las acusaciones de infanticidios, vejaciones sádicas, envenenamientos masivos, conjuras internacionales, violaciones de mujeres, orgías sangrientas, y todo aquello que se esconde como deseo contenido:

la mímica indisciplinada es el sello del antiguo dominio (Herrschaft), que se impregna en la sustancia viviente de los dominados y en virtud de un proceso inconsciente de imitación llevado a cabo en la temprana infancia a través a lo largo de generaciones, desde el judío que vende baratijas (Trödeljuden) hasta el banquero. Tal mímica suscita la ira, porque delata las nuevas relaciones de producción, el antiguo miedo a estar expuesto que ha debido ser olvidado para sobrevivir. [DA: 207] (DI: 226)

Por lo tanto, la instrumentalización totalitaria de la rebelión de la naturaleza necesita de los judíos en tanto que, por un lado, estos son "hijos legítimos de la civilización pagana" [DA; 205] (DI: 229) -los que propagaron el individualismo, y el sujeto de la modernidad, los que dieron origen a las relaciones burguesas, ciudadanas y al cosmopolitismo, los que introdujeron el monoteísmo y el 
capitalismo-, pero, al mismo tiempo, representan la "felicidad sin poder", la mentira del liberalismo, la explotación de la sociedad del intercambio que se materializa ilusoriamente en la esfera del comercio, los instintos, lo arcaico, la fortaleza de la conjura y la debilidad del intelectual, es decir todo aquello que la modernidad quiso dejar de lado. Según esta lectura podemos ver que los judíos, a los ojos del antisemita, representan lo más poderoso y lo más débil al mismo tiempo, lo más avanzado de la modernidad y lo que modernidad debió superar como pasado vergonzoso.

Pareciera que la representación del judío tiene que ser necesariamente ambigua debido a la ambigüedad esencial de la modernidad. Como represores de la naturaleza y como naturaleza reprimida, el judío representa el nervio íntimo de la civilización; por eso aquellas capas atrasadas de la sociedad, que en su impotencia se identificaron con el poder que los oprimía, lo persiguieron sin descanso. Es decir, para Adorno la persecución antisemita es parte esencial de la civilización, puesto que, los resentimientos y los malestares que esta creó, sólo pudieron tener su bomba de escape proyectando los rasgos reprimidos de esa civilización sobre un objeto socialmente ambiguo. El judío es, en definitiva, lo que no puede ser asimilado al principio de identidad y el supuesto representante del principio de identidad, el punto de armado y desarmado de todo el edificio moderno: en definitiva, el núcleo contradictorio del totalitarismo, que a su vez es el núcleo contradictorio de la modernidad. Por lo tanto, modernidad, totalitarismo y antisemitismo encuentran su juego de reciprocidades en estas reflexiones, donde cada uno es la "esencia oculta" del otro, donde cada término no puede ser entendido sin la presencia del otro término.

En estas reflexiones Adorno no procedió indagando en la historia de los pogroms o de la "solución final", ni tampoco elaboró una sociología de los comportamientos racistas, sino que reflexionó sobre las continuidades internas y los aspectos contradictorios de la modernidad, en esos huecos que hicieron posible la modernidad liberal pero que no podían ser integrados completamente a él, y cuya figura paradigmática fue el antisemitismo. Como vimos, el judío 
representaba al banquero, al comerciante, al asimilado cosmopolita, al intelectual, aglutinaba en torno de sí el conjunto de las representaciones de aquello que estaba en la base de la modernidad y del orden liberal -el comercio, el espíritu, el derecho, las relaciones ciudadanas...-, pero, al mismo tiempo, se mantuvo siempre como algo externo ya que representaba también todo lo que la modernidad liberal había sacrificado para forjar su fisonomía: la naturaleza dominada, la felicidad sin poder, lo no idéntico, el reino de las pasiones, la sensibilidad intelectual.... En esta doble y ambigua representación del judío es que la modernidad nos muestra a la vez su fisonomía contradictoria, su "dialéctica de la ilustración".

En otras palabras, al entender al judío como síntoma de la rebelión de la naturaleza, Adorno indagó el relato que se da a si misma la modernidad, a la que él identifica con el liberalismo -el liberalismo económico basado en el intercambio mercantil y el liberalismo político-moral basado en los principios de igualdad jurídica y tolerancia-. Su trabajo consistió en detectar el núcleo que le otorga fundamento a la modernidad y que a la vez la subvierte, aquello que hace posible pero que a la vez es contradictoria con la misma; es decir, buscó abrir el cierre discursivo de la ideología liberal mediante un sutil y arriesgado procedimiento crítico: reconociendo el núcleo contradictorio del liberalismo en el totalitarismo, el núcleo contradictorio del totalitarismo en el judío, y en el judío la ambigüedad que lo hace posible como núcleo contradictorio. La crítica adorniana demostró entonces la conexión conceptual entre modernidad liberal, totalitarismo y antisemitismo, derivando de modo inmanente uno de otro, y demostrando que en el fundamento de ese conjunto de equivalencias se esconde un sustrato contradictorio.

Ahora bien, es notorio que al pensar el antisemitismo en estos términos se pierde en parte la singularidad del fenómeno ya que no interesaría el conjunto de decisiones políticas y el funcionamiento de las instituciones en que se manifestó el antisemitismo en Alemania, o el modo en que esto devino en la aplicación de 
medidas sistemáticas de exterminios durante el Tercer Reich, también adolece de un análisis de la dinámica social o de la estructura de clases de la sociedad alemana. Tampoco cuenta el plano de la decisión individual y de la atribución de responsabilidades concretas por parte de los perpetradores -por lo que incluso estas reflexiones hasta podrían llegar a ser usadas con fines exculpatorios-. Por supuesto que estos no son problemas teóricos menores, y que un análisis del antisemitismo en sus términos históricos o sociales necesita de otro tipo de estudio. Sin embargo, consideramos que estas reflexiones nos permiten pensar las líneas de continuidad de lo sucedido durante el nazismo con la tradición, y al mismo tiempo pensar la necesidad de ruptura con dichas continuidades. Es decir, nos permite ver el fenómeno como una persistencia de ciertos núcleos conflictivos de la modernidad.

Esto quedará mejor explicado si ahora analizamos qué tipo de relación con nuestro pasado reciente está vinculada con esta forma de concebir la modernidad. Para esto vamos a discutir a continuación con la propuesta de Habermas al respecto.

\section{El pasado reciente como problema}

Para plantear el vínculo que podría haber entre determinada concepción de la modernidad y la relación con nuestro pasado reciente, indagaremos en una célebre discusión pública que surgió en Alemania entre 1986 y 1989 y que se denominó Historikerstreit ("Controversia de los historiadores") ${ }^{33}$. El debate surgió a raíz de un artículo de Jürgen Habermas en el semanario de orientación liberal Die Zeit, en el cual confrontaba con algunos historiadores que habían emprendido por esos años un revisionismo histórico como un intento de volver aceptable el pasado

33 Un buena presentación de los principales términos de la Historikerstreit puede encontrarse en "The Historikerstreit in context" de Peter Baldwin que sirve de Introducción a la compilación del mismo Baldwin llamada Reworking the Past. Hitler, the Holocaust and the Hstorians' Debate (Baldwin, 1990). 
nacionalsocialista para la conciencia pública alemana. La figura más importante de estos historiadores fue la de Ernest Nolte, para quien el genocidio judío debía ser leído como una "respuesta exagerada" a las matanzas de clase estalinistas en la década del $30^{\circ}$. En esa relación causal el Holocausto aparecía normalizado al ser comprendido como un eslabón más dentro de una larga cadena de genocidios ${ }^{34}$.

Pero lo que nos interesa aquí es la posición de Habermas en la medida en que guarda un particular contraste con el modo en el que Adorno entiende la historia y la relación con el pasado. Lo que Habermas cuestiona a los historiadores como Nolte no es la idea de que los alemanes entablen una relación con su pasado despojada de culpa, sino que esa liberación de la culpa se efectúe bajo los intentos de reconstruir un nacionalismo particularista vinculado a una tradición antidemocrática, violenta y totalitaria; tradición que separaría a Alemania del vínculo con Occidente consumado luego de la Segunda Guerra Mundial y que, según Habermas, debería ser profundizada, es así que:

Lo que se debate no es la pertenencia de la República Federal a la Europa occidental, sino la cuestión planteada por parte conservadora de si la opción por Occidente no debería quedar anclada en una renovada conciencia nacional, capaz de calar en toda la población.(Habermas, 2007: 84).

Habermas no pone en cuestión el intento revisionista de recuperación de una relación "más sana" con un pasado alemán libre de culpa, sino que propone que esa relación debe ser construida en otros términos; esto significa, para Habermas, que esa relación debería darse a partir de la articulación de una "identidad posconvencional" basada en normas de carácter universal y en el seguimiento por parte de los ciudadanos de un "patriotismo constitucional" alejado de cualquier nacionalismo sustancialista y dogmático. Estos ideales abstractos deben hacerse concretos en una relación con la tradición que priorice una apropiación selectiva como un modo de encauzar compromisos válidos democráticamente y capaces de hacer posible "condiciones de convivencia y

34 Los artículos que originaron el debate son "Zwischen Geschichteslegende und Revisionismus?" y el más célebre " $V$ 
comunicación de formas de vidas diversas, provistas de iguales derechos y coexistentes" (Ibídem.: 101). Habermas remarca la importancia de una decisión de carácter crucial que modifique en forma consciente y responsable la propia identidad y que, basada en una discusión pública, escoja qué es lo que debe considerarse valioso y lo que no, al tiempo que permita establecer cómo se entienden los propios alemanes como ciudadanos de su país.

Contrariamente a la aceptación pasiva de una carga de culpa, la relación con el pasado para Habermas consistiría ciertamente en un compromiso crítico con una historia común. Se trataría en todo caso de renovar el consenso antitotalitario que se consumó luego de la posguerra reasumiendo las tradiciones de Occidente, no sólo en sus aspectos económicos, sino también en sus opciones políticas y culturales. En definitiva, lo que la Historikerstreit habría peligrosamente revelado sería la posibilidad de una "ruptura de este compromiso" que pondría a los alemanes "por primera vez explícitamente ante la cuestión de qué significa en verdad para nosotros esa orientación hacia Occidente" (Ibídem.:104). Se trata para Habermas de apelar a la conciencia y a la reflexión para poner entre un paréntesis crítico el pasado nazi y reasumir de forma mediada la tradición democrática occidental, o como dice en otro artículo: "El período nazi será menos un obstáculo para nosotros mientras más calmadamente podamos considerarlo como un filtro a través del cual la sustancia de nuestra cultura deberá ser procesada" (Habermas, 1988: 45).

La operación consistiría entonces en purificar al pasado alemán para asumir libremente la tradición ilustrada occidental. Esta idea de un "filtro", por medio del cual debe pasar parte de la tradición, implica la posibilidad de diferenciar al menos dos caminos posibles: o de tomar las potencialidades de una "modernidad cultural" como base para la realización individual, la consumación de una ética universal y formas políticas democráticas, o bien aferrarse simplemente a una "modernidad social" basada en los logros económicos y administrativos de las sociedades occidentales -la opción por los beneficios de una "modernidad social" conjugado con el desprecio por los logros de la "modernidad cultural" es lo que Habermas 
caracteriza como la posición de los "neoconservadores" (Habermas, 2008: 16-22)

-. En este sentido puede entenderse que, para Habermas, la historia alemana tomó un "camino especial" (Sonderweg) alejado de la tradición democrática europea que sólo puede ser reencauzado en forma de una identidad postradicional expresada en un patriotismo procedimental, que asegure una vuelta a los principios del Occidente ilustrado:

El único patriotismo que no nos hace extraños a Occidente es el patriotismo constitucional. Un compromiso con principios constitucionales universales que sólo pudo ser afianzado como convicción en la cultura nacional alemana desde -y gracias- a Auschwitz. (Habermas, 1988: 39)

Este "patriotismo constitucional" o esta aceptación de la "modernidad cultural" se presentan como el único remedio contra la tradición de violencia del pasado nacionalsocialista. Las posibilidades de cuestionar ese pasado sólo se harían posibles para Habermas en el marco de las democracias occidentales basadas en principios procedimentales de carácter universal. Ahora bien, el problema de esta argumentación es que mientras se alaban las posibilidades de cuestionar racionalmente todo tipo de fetichización que se hace posible sólo en el marco de las sociedades occidentales, al mismo tiempo se fetichiza esa sociedad en tanto no se pone en duda el suelo de violencia y autoritarismo sobre el cual fue instaurada. La forma social que hace posible la crítica al pasado no es sometida, a su vez, a una crítica que logre hacer visibles los compromisos que esa sociedad mantiene con aquello que desea negar. En este sentido vale la siguiente observación que realiza Vincent Pecora con respecto a la posición de Habermas:

Los escritos de Habermas callan de manera uniforme el obvio dato histórico de que la "ilustración" y la "modernidad" casi siempre llegaron a Occidente a costa de pueblos explotados y colonizados, cuya mano de obra, territorio, recursos y mercados atizaron su "modernidad social", pueblos cuya existencia se ha visto ignorada o negada de manera más o menos uniforme por las grandes instituciones de la modernidad cultural de las que Habermas es el abanderado. (Pecora, 2007: 242). 
Independientemente de que esa ilustración occidental otorgue los potenciales para una crítica y para una articulación de formas de vida divergentes en marcos democráticos, es necesario tener presente que esa misma ilustración fue el producto histórico de una exclusión "no consensuada" ni pasada por el "filtro" crítico de los que la padecieron. La imposición de los valores occidentales en África, en Asia y en América fue siempre por la vía del fusil y no del "mejor argumento". Por lo tanto, la idea de racionalidad occidental, si es que quiere ser justamente defendida y sostenida, debe proceder con una autorreflexión crítica sobre su misma condición histórica de implantación. Es justamente esta obliteración en los análisis que realiza Habermas lo que los textos de Adorno posibilitan plantear: en donde Habermas ve un mecanismo racional transparente, Adorno observa el suelo de barbarie que ese mecanismo ha debido dejar atrás para poder funcionar, en donde Habermas piensa un compromiso que diferencie claramente un presente democrático de un pasado cargado de culpa, Adorno ve líneas de continuidades que deben ser primero llevadas a reflexión. De este modo, la violencia, como aquello que suspende el consenso, es mucho mejor captada en Adorno que en Habermas ${ }^{35}$. La violencia, como aquello que suspende el consenso, es mucho mejor captada en Adorno que en Habermas. En ese sentido la crítica que Habermas realiza de la caída en una "contradicción performativa" del pensamiento adorniano despierta la siguiente respuesta de Pecora:

]"Habermas nunca está más en lo correcto que cuando apoya los imperativos de la reflexión razonada ante los impulsos contra-fácticos, racistas o irracionales en su propio país. Pero

35 En un sugerente estudio sobre las diferencias entre las filosofías de Adorno y la de Habermas Deborah Cook ofrece una distinción interesante que puede ayudar a profundizar más en esto que venimos señalando a propósito de ambos autores. Para esta autora la obra de Habermas estaría más bien referida: "...no fundamentalmente a los individuos, sino a formas colectivas de vida, en las cuales los individuos se forman desarrollando sus personalidades a partir de la identificación con grupos sociales, valores y metas colectivamente compartidos. En agudo contraste con esta perspectiva, Adorno conceptualiza lo particular como individuos concretos y espacio-temporalmente determinados, que surge del suelo primitivo del ser de la especie debido a desarrollo histórico de su capacidad de autorreflexión [...]. De acuerdo con Adorno, la vida del individuo particular es la verdadera sustancia del universal" (2005, 156; nuestra traducción), puesto que "su idea utópica de reconciliación prefigura una sociedad más radicalmente pluralista que la que Habermas puede permitir ya que esta acomodaría a cada individuo en su concreta particularidad" (ibídem, 157; nuestra traducción). Quizá esta diferencia con respecto a la tensión entre particularidad y universalidad pueda ofrecer algo de luz sobre las diferentes disposiciones críticas con respecto a la modernidad que ambos autores presentan. 
abortar la reflexión crítica donde él lo hace es la auténtica "contradicción performativa" en el pensamiento occidental." (Ibídem.: 258).

Es interesante realizar la analogía con un trabajo que escribió hace unos años en un tono muy "adorniano" un historiador; me refiero al trabajo de Enzo Traverso La violencia nazi. Una genealogía europea. Allí Traverso desarrolló las posibilidades historiográficas que tendría un análisis que mire las continuidades ocultas que se esconden detrás de esa modernidad que Habermas intenta rescatar mediante un "filtro" racional. Traverso puso en relación los métodos de terror del nazismo con ciertos elementos y procesos que se encontraban en el corazón mismo de la cultura europea. Más precisamente, consideró que el nazismo no puede ser comprendido sin en las masacres cometidas por los países centrales durante las guerras coloniales, en la medida en que "el nazismo permitió el encuentro y la fusión de dos figuras paradigmáticas: el judío, el 'otro' del mundo occidental, y el 'sub-hombre', el 'otro' del mundo colonizado" (Traverso, 2002: 27). Para Traverso si bien el laboratorio de la violencia nazi fueron las matanzas cometidas por los europeos durante la Gran Guerra, esta violencia encuentra sus condiciones "genealógicas" en ciertos elementos centrales de la cultura moderna europea, tales como la modernización técnica aplicada a los dispositivos de asesinato, los estereotipos racistas presentes en el cientificismo de fines del siglo XIX, la burocracia administrativa y la estigmatización de las clases marginales como enfermedad social. Todos estos elementos vinculan componentes centrales de la modernidad europea (la técnica, la ciencia, el derecho y la administración del estado, la revolución productiva que provocó masas de desposeídos) con la configuración de una violencia de nuevo cuño, como lo fue la violencia nacionalsocialista.

A diferencia de Traverso el análisis de Adorno procede en términos de continuidades conceptuales, o mejor dicho intenta indagar en el ethos que configura esas instituciones y esos acontecimientos modernos que Traverso tan apropiadamente indaga en su libro. Pero lo interesante es que a diferencia de 
Habermas, para Adorno la relación con el pasado reciente no puede basarse en una decisión tajante en la que determinadas tradiciones sean escogidas sobre otras, fundamentalmente debido a que aquella tradición que se escoja estará siempre ya atravesada por esos males que se desean exorcizar, y que seguirán operando si no son llevados a reflexión. Como vimos en las líneas precedentes, con sus reflexiones sobre el antisemitismo Adorno saca a luz la relación entre la cultura política occidental y la violencia que esa cultura política ejerció sobre otras culturas: en este marco el judío fue el grupo más sistemáticamente marginado y oprimido en la historia de Occidente, pero al mismo tiempo representó también lo que esa cultura había tenido que reprimir para poder constituir su identidad. Lo interesante de este enfoque es que, si bien en desmedro de una historización adecuada, el antisemitismo es visto en continuidad dentro de una civilización afianzada sobre la violencia (como violencia de clases, como violencia contra la naturaleza, como subjetivación de la división social de funciones) que, finalmente, desemboca en violencia exteriorizada hacia otras formas culturales: como vimos el judío es lo no- occidental dentro de Occidente, lo que Occidente desea extirpar pero sin ser capaz de hacerlo porque es parte de su misma sustancia.

Por eso repensar estas reflexiones sobre el antisemitismo puede ayudar a ver lo que Habermas no ve: la violencia de la modernidad cultural hacia afuera como condición de esa misma modernidad y una violencia auto-infringida de parte de esa misma modernidad, como represión de la naturaleza y como homogeneización de lo diferente. Es por esto que consumar una relación reflexiva con el pasado reciente no significa para Adorno abandonar el pensamiento, la racionalidad o la disposición crítica, tampoco implica salirse por fuera del juego democrático o abjurar de los principios de tolerancia e igualdad civil que posibilitó la modernidad, sino que conlleva la exigencia de pensar hasta el final esa misma tradición en toda su ambigüedad, pensar esa tradición como represión de las pasiones y lo afectivo, como violencia y división de clases, como consumación y opresión de lo diferente. En un texto de 1959 intitulado "Qué significa superar el pasado reciente" (Was bedeutet: Aufarbeitung der Vergangenheit) Adorno afirma los siguiente: "probablemente lo esencia sea de qué modo traemos el pasado al 
presente (vergegenwärtigt wird), si nos quedamos en el mero reproche o enfrentamos el horror mediante la fuerza de pensar aún hasta lo impensable (das Unbegreifliche)" [EG II: 569] (IN: 729).

\section{CONCLUSIONES}

El eje de este trabajo consistió en pensar la relación entre la crítica al concepto de sujeto en la filosofía de Adorno y el imperativo categórico que exigía la no repetición de Auschwitz. Tratamos de mostrar que ese imperativo implicaba una autocrítica de la tradición filosófica, a los fines de sacar a luz aquellos elementos de la cultura que fueron cómplices de la barbarie. Para Adorno, Auschwitz no se trató solamente de un acontecimiento histórico, sino que dictaminó el fracaso entero de la cultura como suelo en el que se desarrolló la vida de los hombres. De ese modo, su imperativo categórico tenía como fin acentuar la obligación de la filosofía de entablar una autocrítica radical, ya que sus conceptos también habían sido responsables de las condiciones culturales en las que el Holocausto tuvo lugar. Es por esto que Adorno se propone repensar el núcleo subjetivista de toda la filosofía moderna para develarla en su compromiso con la barbarie. A lo largo de estas líneas intentamos mostrar de qué modo la figura del sujeto moderno, y la forma de racionalidad que le fue constitutiva, constituyeron el espacio en el cual fue forjado el ethos que actuó como condición de posibilidad de Auschwitz. Ese suelo cultural, del cual el nazismo y sus campos de concentración

fueron legítimos herederos, fue el molde que permitió perfilar la sensibilidad y la subjetividad de los verdugos y de sus cómplices, fue el manto que permitió la naturalización de la masacre como acontecimiento históricamente posible.

Esperamos haber tenido éxito en leer la obra de Theodor Adorno atravesada por preocupaciones históricas que se traducen en un filosofar cargado de responsabilidad moral, en mostrar en definitiva cómo la reflexión filosófica y la preocupación histórica entran en tensión en el suelo de su obra. 
Pero al mismo tiempo esto nos permitió reponer su obra en el centro de los debates filosóficos del siglo XX, debates que se dieron como un ajuste de cuentas con el subjetivismo que atravesó toda la filosofía moderna. En nuestro recorrido no sólo intentamos poner en sintonía la crítica adorniana con las condiciones culturales que él consideraba estaban en la trasfondo de la barbarie histórica, sino que intentamos, de igual manera, rescatar la particularidad dialéctica y normativa de su crítica. De ese modo, planteamos que el principal problema del concepto moderno de subjetividad fue su incapacidad para abrigar la posibilidad de una experiencia que pudiera dar cuenta de la heterogeneidad de lo real $y$, de ese modo, propiciar una relación exenta de violencia en el mundo social. Fue esa configuración de la subjetividad la que se hizo fisonomía en los individuos, fue su racionalidad la que actuó como patrón de comportamientos reificados hasta caer en la máxima de las irracionalidades. Repasemos brevemente el trayecto recorrido para ofrecer algunos comentarios que logren sintetizar y dejar más en claro lo ya expuesto.

El concepto moderno de sujeto fue pensado como portador de una racionalidad que era capaz de otorgar sentido a todos los ámbitos del mundo, que permitía tanto un conocimiento verdadero de la realidad como un accionar eficaz. Racionalidad que era perfectamente capaz de definir completamente los fenómenos o de dar con las leyes que los gobernaban. Sujeto y racionalidad fueron términos que la tradición siempre consideró como equivalentes y como reductibles uno a otro. Según nuestra lectura, Adorno va a mostrar que la racionalidad, tal y como fue concebida por la tradición, es en realidad sólo un aspecto en el encuentro entre el sujeto y su mundo, y que ese sujeto racional no es algo autónomo, sino el producto de una serie de instancias previas no necesariamente racionales. El problema fue entonces que la racionalidad de ese sujeto moderno fue siempre una racionalidad unilateralmente concebida que suponía una relación instrumental y dominadora con respecto a todo lo que no fuera esa misma subjetividad. Esto para Adorno implicó un empobrecimiento en ese sujeto puesto que en toda experiencia es necesario siempre un componente objetivo, un plus como algo no dado previamente. Eso no idéntico al sujeto es lo 
que le daría no sólo la oportunidad de una autorreflexión, en tanto una vuelta refleja sobre sí mismo, si no también le permitiría entablar relaciones enriquecidas con el mundo, en la que pudiera establecer una auténtica comunicación con una otredad.

Para trabajar esta crítica adorniana partimos de un fragmento en el que consideramos estaban contenidos todos los elementos del análisis. Según este fragmento la "ideología del sujeto" se produciría cuando consideramos que:

[...] las intervenciones, las intelecciones, el conocimiento, son solamente subjetivos [...]. Ilusión es el encantamiento del sujeto en su propio fundamento de determinación; en su posición como ser verdadero. Es preciso retrotraer al sujeto mismo a su objetividad; no se trata de proscribir sus impulsos del conocimiento. [SW: 749] (Con; 150)

Esta idea de un sujeto encerrado en su propia determinación y represor de toda objetividad ajena a su propia esfera fue el eje de nuestro estudio. En los tres capítulos intentamos profundizar este esquema y ver su resolución en distintos planos. En el primer capítulo, en el marco de la relación entre el hombre con su naturaleza. En el capítulo dos, en el marco de la crítica al gran tema de la filosofía moderna, el problema del conocimiento. Y en el capítulo tres, en el marco de la explicación del antisemitismo y su relación con la modernidad cultural. Repasemos brevemente este recorrido.

En el primer capítulo mostramos cómo, a partir de una historia natural, ese sujeto se constituía en una imbricación con un origen biológico La racionalidad que él portaba era entendida fundamentalmente como una herramienta de autoconservación en una larga lucha por la supervivencia llevada a cabo por la especie. En ese camino el dispositivo racional comenzaba a autonomizarse por sobre otros modos de relacionarse con el mundo. Autonomización que exigía paralelamente un cierre de las estructuras subjetivas y la constitución de un yo diferenciado que pudiera mantener el control sobre las pulsiones y sobre los instintos. Lo que Adorno describía con su historia natural era la progresiva independización de un modelo de racionalidad y de un determinado tipo de 
subjetividad, caracterizado por la represión de toda naturaleza interna y la redirección de los impulsos y los elementos somáticos en función de la reproducción social. De este modo, vimos que la actividad social del trabajo y la disposición al placer quedaban culturalmente disociadas; al mismo tiempo, vimos que los componentes sensuales y placenteros no ligados a la producción eran neutralizados como esferas sociales en el arte o la cultura.

Estos mecanismos de represión se solidificaron y consumaron al sujeto racional en la filosofía, extirpando al mismo tiempo la conciencia del vínculo primitivo con el trabajo de supervivencia de la especie. El problema para Adorno consistió en que esta racionalidad sólo pudo abrigar una relación instrumental y cosificadora con el mundo. A este modelo de sujeto racional la realidad se le presentaba como un cúmulo de materiales que debían ser catalogados, cuantificados y finalmente dominados; para facilitar este trabajo el sujeto debía mantener la misma relación instrumental con su realidad interior. Entonces, lo que intentó mostrar Adorno con su historia natural fue la vinculación de la razón y el sujeto con ese mecanismo de autoconservación biológico; intentó develar que detrás de la idea de razón se escondían procesos de represión de toda dimensión sensitiva para lograr el aseguramiento de un yo centralizado que pudiera hacerse cargo de las funciones reproductivas. El sujeto así constituido era ya un sujeto mermado en sus capacidades sensitivas, endurecido como dispositivo de supervivencia y que sólo podía entablar una relación de dominación con la naturaleza y consigo mismo. Relación de domino que, según el análisis de Adorno, luego se va a generalizar al interior de la sociedad como paradigma de toda relación intersubjetiva.

En nuestro segundo capítulo vimos cómo esta subjetividad solidificada como herramienta de autoconservación biológica fue la que se sedimentó en los conceptos de la filosofía. Para Adorno la racionalidad que determinó nuestro contacto con el mundo natural es también la racionalidad que se insertó en el seno de la filosofía, y que tiene su máxima expresión filosófica en la teoría del conocimiento moderna. Fiel al programa lukaciano de leer la filosofía como un 
lugar en el que se sedimentan procesos estructurales de la sociedad, Adorno estudió al sujeto filosófico en continuidad con los mecanismos de autoconservación y reproducción social, ya revelados mediante su "historia natural". De ese modo, pudo observar que la relación prioritaria que este sujeto cognitivo mantenía con toda objetividad fue la identificación y subsunción del objeto en sus propios esquemas subjetivos. Por lo tanto, la crítica a la teoría del conocimiento constituía también una crítica a la forma de racionalidad social y a la forma de subjetividad a ella vinculada. Para Adorno esta subjetividad de la teoría del conocimiento no sólo estará determinada como autoconservación biológica, sino que también estará estructurada sobre el principio de intercambio mercantil que se generaliza socialmente. Del análisis marxiano del fetichismo de la mercancía Adorno extrajo el análisis de la forma de racionalidad allí consumada, en tanto lógica de abstracción de las particularidades y de cuantificación de lo cualitativo. Puesto que Adorno confiaba que son las relaciones mercantiles las que articulan y cohesionan el todo social, entonces consideró que esas mismas relaciones sociales eran las que se reproducían al interior de los conceptos; es por esto que el sujeto de la filosofía homogeneiza y adecua la variedad sensible y la particularidad que presenta el mundo a sus estructuras abstractas ya previamente constituidas -del mismo modo que el valor de uso al transformarse en valor de cambio en virtud del intercambio amputa lo particular una consideración cualitativa de un tiempo de producción abstracto-.

Entonces esta racionalidad tendría un doble condicionamiento: por un lado una determinación en lo biológico como herramienta de autoconservación -como vimos en el capítulo I-, y por otro lado como igualación abstracta según el modelo del intercambio mercantil -como acabamos de observar a propósito del capítulo II-. Esto no representa ningún condicionamiento en algún sentido determinista, sino que podemos decir que es la misma estructura de dominio lo que se reproduce en el yo construido sobre lo biológico y que, mediante la generalización del intercambio de mercancías, se sedimenta en el sujeto de la teoría del conocimiento. Es así que tanto la supervivencia biológica, como las relaciones capitalistas y el fenómeno del conocimiento, son estudiadas por Adorno como 
instancias generalizadoras y reproductoras de un tipo particular de racionalidad y de posicionarse con respecto al mundo. Se trataría entonces de un tipo de sujeto racional que nada sabe de particularidades, que no es capaz de entablar sino una relación de dominación y sofocación con aquello que no puede ser inmediatamente subsumido a sus categorías -sea otro, sea su propia interioridad-. Lo que estructuraría ese sujeto sería entonces el "principio de identidad", que no debe ser pensado como un principio o como un esquema ya preformado, sino como una forma de racionalidad que se reproduce en las prácticas, como una regla de acción que procede identificando casos singulares como ejemplos de una generalidad, como casos incluibles bajo categorías subjetivas previamente dadas.

En nuestro trabajo intentamos mostrar que el principal problema del sujeto tiene ver con su incapacidad para abrigar experiencias que puedan salirse de esas estructuras o que no estén completamente determinadas por el principio de identidad. Adorno pensará trascendentalmente las condiciones de un conocimiento genuino según el modelo de una experiencia de carácter procesual, en el que los esquemas subjetivos son paulatinamente quebrados en una relación con una alteridad; de este modo, el conocimiento se trataría de un proceso experiencial no subjetivista en el que el objeto posee siempre la prioridad. Dicho proceso implicaría un enriquecimiento de las capacidades del sujeto, pero para tal cosa será necesario que la objetividad no sea completamente deducida de la subjetividad, o bien que el sujeto proceda de forma no identificante con respecto a ella, que entable una relación no asentada en la manipulación o en la identificación de lo que desea conocer. Estas serían entonces las condiciones que Adorno, a partir de un análisis del fenómeno del conocimiento, impone para toda experiencia, es por esto que su análisis de la relación sujeto-objeto lo lleva a plantear una forma de subjetividad dada no cognitivamente, una subjetividad ampliada en una relación distinta, emotiva, mimética, afectiva y pacífica con una otredad.

Ahora bien, esta relación sujeto-objeto pensada en términos trascendentales -como búsqueda por las condiciones de posibilidad de una experiencia auténtica-, y en términos materialistas -asentado en la prioridad de lo 
no-idéntico- nos permitirá afirmar que, a partir de la obra de Adorno, se podría pensar el fenómeno del antisemitismo en el marco de una teoría filosófica de la subjetividad. Eso lo realizamos en el tercer capítulo donde leímos los análisis del antisemitismo como la actualización histórica de una subjetividad empobrecida en sus capacidades experienciales.

El antisemita es alguien con sus capacidades experienciales frustradas que sólo puede entablar relaciones intersubjetivas de violencia e identificación según el modelo de un sujeto sin objeto. Este sujeto funciona de forma automática ya que está incapacitado para entablar un proceso de autorreflexión en el que los prejuicios subjetivos puedan ser desmontados en un encuentro experiencial con una singularidad heterogénea. Adorno precisa este modelo describiendo el funcionamiento psíquico del antisemita según los esquemas de proyección y esquematización. En el primer caso, el antisemita acentúa desproporcionadamente el aspecto activo de la experiencia y procede a insertar en el otro sus propias determinaciones; en el segundo caso se acentúa el aspecto pasivo en tanto el sujeto es incapaz de reconocer la singularidad de la alteridad debido a la fijeza de sus esquemas de reconocimiento. Pero, en definitiva, tanto la proyección como la esquematización son aspectos de una estructura que no puede reconocer ningún tipo de externalidad. El antisemita como sujeto que realiza sus experiencias según los mecanismos de proyección y esquematización es también el individuo de masas, cuyos impulsos están en función de la adaptación a las estructuras sociales y se mueve como mecanismo automatizado.

Esta idea de un sujeto construido como represión de la naturaleza interna y, por ende, como privado de la capacidad de abrigar experiencias más amplias, está en la base de la comprensión del antisemitismo como un retorno de la naturaleza reprimida. Según el análisis de Adorno, fueron esos impulsos naturales sofocados en la constitución del yo, y nunca reconciliados reflexivamente, lo que volvió de forma no reflexiva, y que el estado autoritario canalizó a los fines de una ampliación de la dominación social. En este marco el antisemita es tanto el sujeto, cuyos impulsos fueron reprimidos y que retornaron irreflexivamente, como el 
sujeto que con sus capacidades experienciales atrofiadas se ve incapacitado para entablar un contacto pacífico con una otredad. Con el análisis del antisemitismo la crítica al sujeto adorniana se cierra y nos da paso a una compresión filosófica del nazismo y de la ocurrencia de Auschwitz en el marco de la modernidad. Con el análisis del antisemita entonces el sujeto de la metacrítica del conocimiento como el de la historia natural tiene su consecuente materialización social.

Intentamos mostrar que el análisis del antisemitismo en términos de una teoría del sujeto exige, asimismo, el análisis de cierto ethos social necesario para el desarrollo de ese carácter reificado; ethos que fue posible porque la modernidad se constituyó como un contexto de progresiva formalización, que terminó configurando un contexto de igualación y abstracción que impregnó todas las relaciones sociales y neutralizó el carácter vinculante de las relaciones morales. La moral nunca fue para Adorno una dimensión limpia y pura de dominación, en ella se plasmaban relaciones de subyugación entre los hombres y procesos de represión de los instintos. Sin embargo, en el análisis dialéctico adorniano, la moral también poseía cierto contenido de verdad en la petición de un trato más humano entre los hombres, tal y como lo expresó el imperativo categórico kantiano. Es ese contenido de verdad de la moral lo que se pierde con el ethos abstracto que se da a partir de la generalización del principio equivalencial de la mercancía durante la modernidad. Esa posibilidad, que si bien nunca se había actualizado, quedaba ahora neutralizada en un contexto de igualación represiva que configuró un estado de cosas en el que las diferencias sociales eran reprimidas e integradas, y en el que se aflojaban las normas que contenían los impulsos destructivos. Adorno lleva esta tesis y afirma que todo el orden social en sus diferentes esferas sufrió un proceso de paulatina homogeneización y abstracción, convirtiéndose en un entramado de unidades abstractas e intercambiables, en el que las relaciones sociales son codificadas mediante el principio de identidad y consumadas como interacciones mercantiles. Es precisamente en este contexto en el que Adorno ve la posibilidad de que la subjetividad cosificada se haya generalizado, y que algo como Auschwitz haya tenido lugar. 
El Holocausto en este marco es comprendido como el resultado de un proceso de integración represiva que encuentra su continuidad con las estructuras civilizatorias sobre la cual fue configurada la subjetividad. En la muerte serializada, anónima y despojada de odio que tuvo lugar en los campos puede ser descifrada la misma forma de racionalidad que atravesó la historia de Occidente y que está en la base de la subjetividad. Esa nueva experiencia de la muerte y la presencia del sufrimiento físico es entonces lo que pone en cuestión toda forma de racionalidad y todo sentido metafísicamente asignado. Luego de Auschwitz la muerte se encuentra desprovista de toda continuidad con la unidad de la vida; aparece como el sinsentido que pone en entredicho todo sentido constituido, el de la experiencia biográfica, el de los relatos justificadores, el de una vida llevada según los designios de una voluntad individual y, por supuesto, el de toda metafísica o teodicea justificadora.

En esto radica la potencia de Auschwitz para condicionar al pensamiento. Lo que ocurrió en los campos hace patente dos instancias que obligan a replantear los sentidos filosóficos construidos: la muerte como destrucción de todo sentido absoluto, y el sufrimiento corporal como denuncia al sujeto de la autoconservación. En nuestro trabajo fue central esta idea de sufrimiento físico como dimensión que toda consideración sobre el sujeto debe tener en cuenta, y que se vuelve mucho más imperiosa luego de la ocurrencia de los campos de concentración: en la medida en que el sujeto fue forjado como igualación de lo diferente, como dominio sobre el placer, como abstracción de las diferencias, como integración de las particularidades, en la medida en que esto fue produjo y reprodujo la forma de racionalidad con la que fueron exterminados millones de personas en los campos de concentración, pero también produjo y reprodujo las privaciones corporales y sensuales que debieron sufrir los individuos, y la forma mutilada de experiencia propia de la cultura que Adorno denuncia.

Volvemos entonces a lo que planteamos en el capítulo primero. "Que Auschwitz no se repita" implica rememorar el sufrimiento físico padecido en la constitución de la subjetividad y que se hizo manifiesto de forma contundente en 
los campos. De lo que se trata es de reconsiderar el sufrimiento que se esconde detrás del sujeto de la filosofía, que fue posible sobre el silenciamiento y la justificación del dolor padecido. En el sufrimiento injustificado se encontraba para Adorno la exigencia filosófica de repensar el concepto de sujeto de la identidad ya que "la más pequeña huella de sufrimiento absurdo en el mundo en que vivimos devela la mentira de toda la filosofía de la identidad (Identitätsphilosophie)" [ND: 203] (DN: 204). Las represiones y los renunciamientos que el sujeto ha debido hacerse vuelven como prescripciones y exigen ser expresados como contenido de la filosofía. Ese componente somático "sobrevive en el conocimiento como su inquietud que lo pone en marcha y cuyo proceso se reproduce debido a su insatisfacción" (op. Cit.). Repensar el sufrimiento que se esconde detrás de la consolidación de la estructura del sujeto racional es, no sólo una necesidad moral sino también, la condición para que los potenciales racionales de ese sujeto puedan ser actualizados. La filosofía que Adorno propone exige una rememoración de la naturaleza mutilada en la constitución del yo, naturaleza sufriente que se hizo visible en los campos, tanto en la forma de padecimiento de las víctimas como en la violencia de los victimarios.

Es en este punto donde nos encontramos ahora: el sujeto moderno no es sólo una ilusio, o una estructura que debe ser desechada, sino que posee un contenido de verdad sedimentado como experiencia histórica que la crítica debe esforzarse por sacar a luz. Esto marca la radical diferencia entre la crítica adorniana y otras críticas filosóficas al sujeto realizadas durante el siglo XX.. De ese modo, el sujeto es también la exigencia de la realización histórica de una subjetividad ampliada. En este marco es que nuestra hipótesis cobra cuerpo, ya que sólo se podría entender cabalmente el imperativo categórico pos-Auschwitz si logramos pensar la constitución de subjetividades que hagan imposible la reproducción de la barbarie. El carácter normativo de esta subjetividad no tiene que ver con un fundacionalismo sino que alude a lo que Gerhard Schweppenhäuser denominó una "moral negativa" ${ }^{36}$. Es en ese sentido negativo

36 En la siguiente cita puede quedar un poco más clara la idea de "moral negativa" en Adorno que Schweppenhäuser sugiere: "Ofrecer un principio moral afirmativo y fundamentar una filosofía moral sobre la naturaleza vinculante de tal principio es precisamente lo que Adorno no desea hacer. En el 
en el que se expresa Adorno cuando dice en sus lecciones sobre filosofía moral que:

"No deseamos saber qué es el bien absoluto, la norma absoluta, incluso tampoco qué es el hombre, o lo humano y la humanidad; pero qué es lo inhumano lo sabemos perfectamente. Y yo diría que el lugar de la filosofía moral hoy hay que buscarlo más en la denuncia concreta de lo inhumano (in der konkreten Denunziation des Unmenschlichen) que en un posicionamiento abstracto y no comprometido sobre el ser del hombre." [PM: 261]

Esta denuncia concreta es lo que se expresa bajo este nuevo imperativo categórico, que establece que Auschwitz no debe volver a ocurrir; imperativo que tiene un doble basamento: por un lado las tareas que la historia impone, es decir la condicionalidad que le impone al pensamiento la ocurrencia de las tragedias del siglo XX; y por otro lado, la naturaleza que se expresa en el impulso moral de considerar el sufrimiento físico del otro: "la exigencia de validez del imperativo categórico está dada por sostener la conjunción de la experiencia histórica con nuestro interés en abolir el sufrimiento" [PM: 349]. Es entonces este planteamiento de la ideología del sujeto lo que nos abre esa dimensión normativa de la crítica llevada a cabo por Adorno: la naturaleza reprimida debe ser liberada como experiencia genuina de consideración del sufrimiento del otro. Será esta exigencia la que en última instancia nos lleva a la dimensión ética y política expresada en el dictum "que Auschwitz no se repita" y lo que permitiría liberar al sujeto de su propio encierro.

Esperamos haber sido capaces de ofrecer satisfactoriamente una lectura de la obra de Adorno como si se tratara de un campo de fuerza en el que la historia y la filosofía dialogan y entran en confrontación. En el que las exigencias de la historia se traducen en ejercicios filosóficos, y en el que los conceptos intentan visibilizar puntos oscuros en el transcurso histórico. Esperamos, en todo caso, haber tenido la capacidad de mostrar las posibilidades de leer filosofía adorniana como documento de suma actualidad y como ejemplo de compromiso histórico.

corazón de su filosofía moral está un imperativo categórico negativamente formulado que dice lo que nunca debe suceder, lo que nunca debe ser" (2004: 345, nuestra traducción). 


\section{BIBLIOGRAFIA}

AAVV: Historikerstreit. Die Dokumentation der Kontroverse um die Einzigartigkeit der nationalsozialistischen Judenvernichtung. München. Serie Piper. 1991.

Adorno, Theodor: „Die Aktualität der Philosophie“ y „Die Idee der Naturgeschichte“ en Philosophische Frühschriften. Frankfurt am Main. Suhrkamp Verlag. 1973. (Actualidad de la filosofia. Trad. José Luis Arantegui Tamayo. Barcelona. Ediciones Paidós. 1991)

Adorno, Theodor: Dialektik der Aufkärung. Philosophische Fragmente (en coautoría con Max Horkheimer). Frankfurt am Main: Fischer Verlag. 2000. (Dialéctica de la llustración. Fragmentos Filosóficos. Trad. Juan José Sanchez. Madrid. Editorial Trotta. 2006)

Adorno, Theodor: Minima Moralia. Reflexionen aus dem beschädigten Leben. Frankfurt am Main. Suhrkamp Verlag. 1951. (Minima Moralia. Reflexiones desde la vida dañada. Trad. Joaquín Chamorro Mielke. Madrid. Editorial Taurus. 1987)

Adorno, Theodor: Zur Metakritik der Erkenntnistheorie. Drei Studien zu Hegel. Frankfurt am Main. Suhrkamp Verlag. 1970. (Sobre la metacrítica de la teoría del conocimiento. Trad. León Mamés. Barcelona. Planeta-Agostini. 1986; Tres Estudios sobre Hegel. Trad. Víctor Sánchez de Zavala. Madrid. Taurus. 1974)

Adorno, Theodor: Probleme der Moralphilosophie. Frankfurt am Main: 
Suhrkamp Verlag. 1996.

Adorno, Theodor: Noten zur Literatur. Frankfurt am Main: Surkamp Verlag. 2003. (Notas sobre Literatura. Trad. Alfredo Brotons Muñoz. Madrid. Akal. 2003)

Adorno, Theodor: Soziologische Schriften I. Frankfurt am Main: Suhrkamp Verlag. 1972. (Escritos Sociológicos I. Trad. Agustín Gonzalez Ruiz. Madrid. Akal. 2004)

Adorno, Theodor: Soziologische Schriften II. Vol. I. Frankfurt am Main: Suhrkamp Verlag. 1975. (Escritos Sociológicos II. Agustín González Ruiz. Madrid. Akal. 2009).

Adorno, Theodor: Prismen, Ohne Leitbild, Eingriffe, Stichworte. En Kulturkritik und Gesellschaft I/II. Frankfurt am Main. Suhrkamp Verlag. 1977 (Crítica cultural y social. Vol I. Trad. Jorge Navarro Perez. Madrid. Akal. 2008; Crítica cultural y social vol. II. Trad. Jorge Navarro Perez. Madrid. Akal. 2009; Consignas. Ramón Bilbao. Buenos Aires. Amorrortu. 2003)

Adorno, Theodor: Negative Dialektik. Frankfurt am Main: Suhrkamp Verlag. 1992. (Dialéctica Negativa. Trad. José María Ripalda. Madrid. Taurus. 1992)

Adorno, Theodor: Ästhetische Theorie. Frankfurt am Main. Suhrkamp Verlag. 1970. (Teoría Estética. Jorge Navarro Perez. Madrid. Akal. 2004)

Althusser, Louis: "Ideología y Aparatos Ideológicos del Estado" en Zizek, Slavoj (comp.). Trad. José Sazbón en Ideología. Un mapa de la cuestión. Buenos Aires: Fondo de Cultura Económica. 2003.

Althusser, Louis: La Revolución teórica de Marx. Trad. Martha Harnecker. México: Siglo XXI. 1970.r 
Arendt, Hanna: Los orígenes del totalitarismo. Trad. Guillermo Solana; Madrid. Editorial Alianza. 2009.

Bakdwin, Peter: The "Historikerstreit" in Contexto en Baldwin (ed.) Reworking the Past. Hitler, the Holocaust and the Historians Debate. Boston. Beacon Press. 1990

Benhabib, Seila: Critique, Norma and Utopia. A Study on the Foundations of the Critical Theory. New York. Columbia University Press. 1986.

Benjamin, Walter: Discursos Interrumpidos I. Filosofía del arte y de la historia. Trad. Jesús Aguirre. Madrid. Taurus. 1989.

Benjamin, Walter: Origen del Drama Barroco Alemán. Trad. José Muñoz Millanes. Madrid: Taurus. 1990.

Bernstein, J. M.: "Negative Dialectic as Fate. Adorno and Hegel" en Huhn, T.: The Cambrigde Companion to Adorno. Cambrigde: Cambrigde University Press. 2004.

Buck Morss, Susan: Orígenes de la Dialéctica Negativa. Theodor Adorno, Walter Benjamin y el Instituto de Frankfurt. Trad. Nora Rabotnikof Maskivker.México: Siglo XXI. 1981.

Callinicos, Alex: El marxismo de Louis Althusser. México DF: Premiá. 1978.

Connerton, Paul: The Tragedy of Enlightment. An Essay on The Frankfurt School. London: Cambrigde University Press. 1980. 
Cook, Deborah (2004): Adorno, Habermas, and the Search for a Rational Society. New York. Routledge.

Cook, Deborah: "Staying Alive: Adorno and Habermas on Self-preservation under Late Capitalism" en Rethinking Marxism, University of Washington, vol 18, $n^{\circ} 3$. 2006.

Dews, Peter: "Adorno, el posestructuralismo y la crítica de la identidad" en Zizek, Slavoj (ed.) Ideología. Un mapa de la cuestión. Trad. Pablo Preve. Buenos Aires. Fondo de Cultura Económico. 2003.

Forster, Roger: "Dialectic of Enlightenment as Genealogy Critique",en Telos. Telos Press. Michigan. No 120. Summer. 2001.

Foucault, Michel: Microfísica del Poder. Trad. Julia Varela- Fernando Alvarez-Uría. Buenos Aires. Ediciones de la Piqueta. 2004

Foucault, Michel: La verdad y las formas jurídicas. Enrique Lynch. Barcelona. Editorial Gedisa. 2010

Foucault, Michel: Nietzsche, Freud, Marx. Trad. Carlos Rincón. Buenos Aires: Ediciones El Cielo por Asalto. 1982.

Freud, Sigmund: Más Allá del Principio del Placer en Obras Completas, vol. XVIII, Trad. José Etcheverry. Buenos Aires: Amorrortu Ediciones. 2008.

Freud, Sigmund: EI Porvenir de una llusión/EI Malestar de la Cultura en Obras Completas, vol. XVII. Trad. Luis López Ballesteros y de Torres. Buenos Aires: Hyspamérica Ediciones. 1988.

Friedman, George: La Filosofía Política de la Escuela de Frankfurt. Trad. Carmen Candioti. México D.F.. Fondo de Cultura Económica. 1986.

Fromm, Erich: El Miedo a la Libertad. Trad. Gino Germani. Buenos Aires. Paidós. 2011. 
Haber, Stéphan: "'El cumplido naturalismo del hombre': trabajo alienado y naturaleza" en Emmanuel Renault (dir.) Los Manuscritos de 1844 de Marx. Trad. Heber Cardoso. Buenos Aires: Nueva Visión. 2008.

Habermas, Jürgen: Teoría de la Acción Comunicativa, vol I., Trad. Manuel Jiménez Redondo. Madrid: Editorial Taurus, 1990ª .

Habermas, Jürgen: Teoría de la Acción Comunicativa, vol II. Trad. Manuel Jiménez Redondo. Madrid: Editorial Taurus. 1990b.

Habermas, Jürgen: El Discurso Filosófico de la Modernidad. Trad. Manuel Jimenez Redondo.Buenos Aires: Editorial Katz. 2008.

Habermas, Jürgen: "A Kind of Settlement of Damages (Apologetic Tendencies)" en New German Critique. New York. Telos Press. Number 44. Spring/Summer 1988.

Habermas, Jürgen: La constelación posnacional. Ensayos políticos. Trad. Pere Fabra, Daniel Gaper Sachse y Luis Pérez Díaz. Barcelona. Ed, Paidós. 2000.

Habermas, Jürgen: Identidades Nacionales y Posnacionales. Trad. Manuel Jiménez Redondo. Madrid. Tecnos. 2007.

Hammer, Esper: "Minding the world. Adorno's critique of idealism" en Philosophy and Social Criticism, University of London. vol $26 n^{\circ} 1.2000$.

Hegel, Friedrich: Fenomenología del Espíritu. Trad. Wenceslao Roces. Fondo de Cultura Económico, Buenos Aires. 2007.

Hyppolite, Jean: Génesis y estructura de la "Fenomenología del Espíritu" de Hegel. Trad. Francisco Fernández Buey. Ediciones Península. Barcelona. 1991 Hohendahl, Peter: "The Dialectic of Enlightenment Revisited: Habermas' Critique of the Frankfurt School" en New German Critique, Special Issue on Jürgen Habermas. Duke University Press. (Spring - Summer, 1985). -1985-

Honneth, Axel: Critique of Power. Reflective Stages in a Critical Social Theory. Trad. Kenneth Baynes. Massachusetts: MIT, Press. 1991. 
Honneth, Axel: Patologías de la Razón. Historia y Actualidad de la Teoría Crítica. Trad. Griselda Mársico.Buenos Aires: Editorial Katz. 2009.

Honneth, Axel: Crítica del Agravio Moral. Patologías de la sociedad contemporánea. Trad. Peter Storandt Diller.Buenos Aires: Fondo de Cultura Económica. 2009b.

Horkheimer, Max: Crítica de la Razón Instrumental. Trad. Muerna-Vogelmann. Buenos Aires. Sur. 1969.

Horkheimer, Max: Sociedad en Transición: estudios de filosofía social. Trad. Joan Godo Costa. Barcelona. Planeta-Agostini. 1986.

Horkheimer, Max: Teoría Crítica. Trad. Edgardo Albizu- Carlos Luis. Buenos Aires. Amorrortu. 2003.

Jarvis, Simon: A Critical Introduction to Theodor Adorno. New York: Routledge. 1998.

Jarvis, Simon: "Adorno, Marx, Materialism" en Huhn, T. (ed.) The Cambrigde Companion to Adorno, Cambrigde: Cambrigde University Press. 2004.

Jameson, Frederic: Marxismo Tardío. Adorno y la persistencia de la dialéctica. Trad. María Julia de Ruschi. Buenos Aires: Fondo de Cultura Económica. 2010. Jay, Martin: Adorno. Trad. Manuel Pascual Morales. Madrid: Siglo XXI. 1988. Jay, Martin: La Imaginación Dialéctica. Una historia de la Escuela de Frankfurt. Trad. Juan Carlos Curuchet. Buenos Aires. Taurus. 1984 Jay, Martin: Marxism and Totality. The Adventures of a Concept from Lukács to Habermas. New York. Polity Press. 1984b.

Jay, Martin: Cantos de Experiencia. Variaciones modernas sobre un tema universal. Trad. Gabriela Ventureira. Buenos Aires. Paidós. 2009. 
Kant, Immanuel: “¿Qué es la llustración?” en Filosofía de la Historia. Trad. Mexico D.F. Fondo de Cultura Económica. 1941.

Kant, Immanuel: Fundamentación de la metafísica de las costumbres. Trad. Manuel García Morente. Madrid. Espasa-Calpe.1983

Kant. Immanuel: Crítica de la Razón Pura.Trad. Pedro Ribas. Buenos Aires. Aguilar. 2010.

Karczmarczyk, Pedro: "Las condiciones y la naturaleza del discurso crítico: el debate entre hermenéutica y teoría crítica" en Revista Discusiones filosóficas. Departamento de Filosofía de la Universidad de Caldas, Manizales, Colombia. Año 11, número 16, enero-junio 2010. 2010.

Kellner, Douglas-Best, Steven: Postmodern Theory: Critical Interrogations. California: The Guilford Press. 1991.

Lukács, Georg: Teoría de la Novela. Trad. Buenos Aires, Siglo XXI. 1966 Lukács, Georg: Historia y Conciencia de clase. Estudios de dialéctica marxista. Traducción Manuel Sacristán. Buenos Aires: Ediciones r y r. 2009.

Mansilla, H. C. F.: Introducción a la Teoría Crítica de la Sociedad. Barcelona. Seix Barral. 1970.

Marcuse, Herbert: Eros y Civilización. Trad. Juan García Ponce. Barcelona. Ariel. 1985.

Marcuse, Herbert: Razón y Revolución. Trad. Julieta Fombona de Sucre. Barcelona. Altaya. 1994.

Marx, Karl: Manuscritos Económico-Filosóficos de 1844. Trad. Miguel Vedda. Buenos Aires: Editorial Colihue. 2004.

Marx, Karl: El Capital. Tomo I. Vol. I. Libro Primero. Trad. Pedro Scaron. Buenos Aires. Siglo XXI. 2002. 
Menke, Christoph: La soberanía del arte. La experiencia estética según Adorno y Derrida. Trad. Peter Storandt Diller. Madrid. Visor. 1997

Menke, Christoph: "Genealogy and critique: two forms of ethical questioning of morality". Trad. Rebecca Morrison. En Tom Huhn (ed.) The Cambridge

Companion to Adorno. Cambrigde: Cambrigde University Press. 2004.

Moutot Gilles: Adorno:Lenguaje y Reificación. Trad. Viviana Ackerman. Buenos Aires: Nueva Visión. 2005.

Nietzsche, Friedrich: "Sobre verdad y mentira en sentido extramoral", Obras Completas, vol. I. Buenos Aires. Ediciones. Prestigio. 1970.

Nolte, Ernest: Después del comunismo: aportaciones a la interpretación de la historia del siglo XX; Madrid. Editorial Ariel. 1995.

O'Connor, Brian: Adorno's Negative Dialectic. Philosophy and the Possibility of Critical Rationality. MIT Press. Massachussetts. 2004.

Pecora, Vincent: "Habermas, Ilustración y antisemitismo" en Friedlander, S. (comp.) En torno de los límites de la representación. El nazismo y la solución final. Bernal. Universidad Nacional de Quilmes Editorial. 2007.

Pérez, Alberto: La Teoría Crítica entre el centro y los márgenes del Instituto para la Investigación Social" en Epistemología, Política y Ciencias Humanas de la Universidad Nacional de Rosario. 2007.

Pastephanou, Marianna: “Ulysse's reason, nobody's fault: reason, subjectivity and the critique of Enlightment" en Philosophy \& Social Criticism, London, vol. 26, n. 6. 2000.

Pollock, Friedrich: "State Capitalism" enStudies in Philosophy and Social Science. New York City: Morningside Heights. 1970.

Rose, Gillian: The Melancholy Science. An Introduction to the Thought of Theodor W. Adorno.Columbia University Press. New York. 1978. 
Rusconi, Gian Enrico: Teoría Crítica de la Sociedad. Trad. Alberto Méndez. Barcelona. Ediciones Martínez Roca. 1969.

Sartre, Jean Paul: Reflexiones sobre la cuestión judía. Trad. José Blanco: Buenos Aires. Sur. 1948.

Schweppenhäuser, Gerhard: "Adorno's Negative Moral Philosophie". Trad. Cara Gendel Ryan - Michael McGettigan. en Huhn, T. The Cambrigde Companion to Adorno. Cambrigde: Cambrigde University Press. 2004.

Schwarzböck, Silvia: Adorno y lo político. Buenos Aires. Prometeo-Universidad Nacional de La Plata. 2008.

Sotelo, Laura: Idea de la historia. La Escuela de Frankfurt: Adorno, Horkheimer, Marcuse.Buenos Aires : Prometeo. 2009.

Tafalla, Marta : Theodor W. Adorno. Una filosofía de la memoria. Barcelona. Herder. 2003.

Traverso, Enzo : La Historia Desgarrada. Ensayo sobre Auschwitz y los intelectuales. Trad. David Chiner. Barcelona. Herder. 1997.

Traverso, Enzo: La Violencia Nazi. Una genealogía europea. Trad. Beatriz Horrac Martín Dupaus. Buenos Aires. Fondo de Cultura Económica. 2002

Vincent, Jean Marie: "La Sociología de Adorno" en Blanc, Alain-Vincent, Jean Marie (dir.) La Recepción de la Escuela de Frankfort. Buenos Aires: Nueva Visión. 2006.

Weber, Max: La Ética Protestante y el Espíritu del Capitalismo. Trad. José Chávez Martínez. Buenos Aires: Editorial Prometeo. 2003.

Wellmer, Abrecht: Teoría crítica de la sociedad y positivismo (1969). Trad. González Hernández Ortega. Ariel. Madrid. 1979. 
Wellmer, Albrecht: Sobre la dialéctica de modernidad y postmodernidad: La crítica de la razón después de Adorno. Trad. José Luis Arántegui. Madrid: Visor. 1993.

Wellmer, Albrecht: Finales de Partida. La modernidad irreconciliable. Trad. Manuel Jiménez Redondo.Madrid: Cátedra. 1996.

Wellmer, Albrecht: "Razón, utopia y dialéctica de la llustración" en Bernstein, Richard (ed.): Habermas y la modernidad. Trad. Francisco Rodríguez Martín. Madrid. Cátedra. 1991.

Whitebook, Joel: "Weighty Objetcs. On Adorno's Kant-Freud Interpretation" en Huhn, T. (ed.): The Cambrigde Companion to Adorno. Cambrigde: Cambrigde University Press. 2004.

Wiggershaus, Rudolf: La Escuela de Frankfort. Trad. Marcos Romano Hassán. Buenos Aires: Fondo de Cultura Económica. 2004. 


\section{INDICE}

Nombre del apartado

RESUMEN

AGRADECIMIENTOS

SOBRE EL MODO DE CITACION

INTRODUCCION

1. "...que Auschwitz no se repita"

2. Sobre la crítica al sujeto

Número de página

2

3

4

6

8

16

26

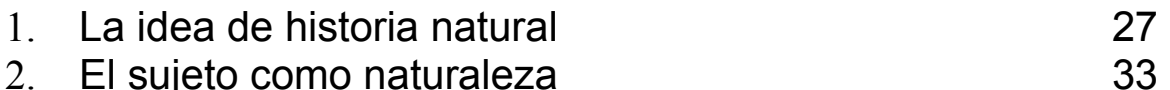

3. Autoconservación 45

4. Sujeto y normatividad 56

II. METACRITICA DE LA TEORIA DEL CONOCIMIENTO 67

1. Metacrítica de la teoría del conocimiento 68

2. Sobre el análisis materialista de la identidad 76

3. La estructura trascendental de la experiencia 86

4. Sobre un concepto de experiencia ampliada 96

5. Algunas consideraciones finales 103

III. ANTISEMITISMO Y MODERNIDAD 108

1. El antisemitismo y el problema de la experiencia 108

2. Modernidad y homogeneización 122

3. Rebelión de la naturaleza, modernidad y nazismo 128

4. El pasado reciente como problema 137

$\begin{array}{ll}\text { CONCLUSIONES } & 144\end{array}$

$\begin{array}{lr}\text { BIBLIOGRAFIA } & 156\end{array}$

$\begin{array}{ll}\text { INDICE } & 165\end{array}$ 